\title{
A TAXONOMIC REVISION OF THE GENUS CEIBA MILL. (BOMBACACEAE)
}

\author{
by \\ PETER GIBBS ' \& JOÃO SEMIR ${ }^{2}$ \\ 'School of Biology, University of St Andrews, Scotland (United Kingdom) visiting CNPq Research Fellow, \\ Universidade Federal de Uberlândia. Minas Gerais (Brazil) \\ ${ }^{2}$ Departamento de Botânica, Universidade Estadual de Campinas. São Paulo (Brazil)
}

\begin{abstract}
Resumen
GrBBS, P. \& J. SEMIR (2003). Revisión taxonómica del género Ceiba Mill. (Bombacaceae). Anales Jard. Bot. Madrid 60(2): 259-300 (en inglés).

En esta revisión taxonómica de Ceiba, que incluye el género Chorisia, se reconocen 17 especies, siete de las cuales se agrupan en el complejo $C$. insignis. Se describe una nueva especie, C. lupuna P.E. Gibbs \& Semir, del Perú, que pertenece al complejo de $C$. insignis, así como una nueva subespecie, $C$. aesculifolia subsp. parvifolia (Rose) P.E. Gibbs \& Semir. Se incluyen mapas de distribución de 16 especies (aunque en el caso de $C$. pentandra solo se representa su distribución americana) y se dibujan detalles diagnósticos de seis especies.
\end{abstract}

Palabras clave: Bombaceae, Chorisia, Ceiba, Sudamérica.

\begin{abstract}
GiBBS, P. \& J. SEMIR (2003). A taxonomic revision of the genus Ceiba Mill. (Bombacaceae). Anales Jard. Bot. Madrid 60(2): 259-300.

In this taxonomic revision of Ceiba Mill. (in which we include Chorisia Kunth) we recognize 17 species, seven of which we group in the $C$. insignis species aggregate. One new species is described, $C$. lupuna P.E. Gibbs \& Semir from Peru, which is referred to the $C$. insignis agg., and one new subspecies, C. aesculifolia subsp. parvifolia (Rose) P.E. Gibbs \& Semir is recognized. Distribution maps are provided for 16 species (that for $C$. pentandra is restricted to the New World), and six species are illustrated.
\end{abstract}

Key words: Bombaceae, Chorisia, Ceiba, South America.

\section{INTRODUCTION}

This revision of the genus Ceiba represents the tardy completion of taxonomic studies we initiated with the genus Chorisia in the early 1980 s. At that time our main research interest was in the breeding system of Chorisia speciosa and related species, and our taxonomic enquiry began because of doubts we had concerning the identity of pale yellow flowered trees listed as "Chorisia insignis HBK" in cultivation at the horticultural section of the Ex- perimental Station of the Instituto Agronômico (Fazenda Santa Eliza), Campinas (São Paulo). We did not solve this particular problem until much later but sporadic taxonomic studies with herbarium material and species represented in the splendid collection of trees of known provenance at the Fazenda Santa Eliza led to a gradual understanding of this group, and our conviction that the genus Chorisia should be merged with Ceiba (cf. GIBBS \& al., 1988). However, our taxonomic research with Ceiba went into abeyance for a 
number of years whilst the first author was involved with studies on the reproductive biology of species of the Brazilian cerrado and Argentine Chaco vegetation, and second author undertook a doctoral thesis on the genus $L y$ chnophora Mart. (Asteraceae).

Fortunately, over the intervening years, with one notable exception, few other people have taken an interest in the taxonomy of species of Ceiba or Chorisia, despite the great beauty of the flowers of these trees, and some confusion concerning their identity. The exception was a paper by RAVENNA (1998). The principle objective of RAVENNA (1998) was to accept Gibbs, Semir and da Cruz's view that Chorisia should be merged with Ceiba, and then to effect all possible recombinations of Chorisa species under Ceiba. No attempt was made to study type material of the species of Chorisia to be recombined, and unsurprisingly, of the seven new combinations effected in this paper, two were superfluous. In addition, two new species were proposed by Ravenna (both rejected in the present revision), together with an unworkable key which purported to identify five of the 10 species considered in his study. Why the key was restricted to just these five taxa was not explained. The paper was produced in the author's own xeroxed series 'Onira Botanical Leaflets' rather than published in a peer-reviewed journal, and so is difficult to access, but since care was taken to ensure that copies were sent to some major botanical institutions, e.g. Royal Botanic Gardens, Kew, effective publication was achieved.

RAVENNA (1988) claimed that GIBBS \& AL. (1988) "believed that Ch. crispiflora HBK, Ch. speciosa St. Hil.. Juss. \& Camb., Ch. ventricosa Nees \& Mart., Ch. integrifolia Ulbr. and $C h$. incana Rob. are referable to $C h$. insignis. The writer's own experience with living material of these and other species in their native habit, cannot allow him to accept Gibbs $\&$ al. opinion". This implies we treated all of these taxa as synonyms of Chorisia insignis, which in this paper we recombined as Ceiba insignis. In fact we commented that these species "form a polymorphic complex or aggregate species... Our detailed studies are not yet complete but it appears that all other species of Chorisia... are referable to it" [i.e. to such a species aggregate]. Mindful of the adage "fools rush in where angels fear to tread", we concluded: "Whether any of these taxa can be maintained at a specific or subspecific level must await the outcome of our analysis of the Ceiba insignis complex." In the event, we recognize here the Ceiba insignis aggregate with seven component species, including a new species $C$. lupuna, and we treat $C h$. integrifolia as a synonym of $C$. insignis s.s., and $C h$. incana as a synonym of C. ventricosa.

GiBBs \& al. (1988) provided a taxonomic history of the genera Ceiba and Chorisia, and a discussion of their alleged differential characters, particularly the nature of the stamen tube, which led us to believe that Chorisia should not be separated from Ceiba. To provide an introduction to this revision, we here include a summary of the views put forward in that earlier publication.

Although used by Plumier (1703: 42), MILLER (1754) provided the first valid publication of the generic name Ceiba, but this was overlooked until DRUCE (1913). As clarified by NiCOLSON (1979), the type species of this genus is Ceiba pentandra (L.) Gaertn. (1791), first published as Bombax pentandrum $\mathrm{L}$. (1753). The generic names Bombax, and subsequently Chorisia, prevailed for this group until Ceiba was re-established by SCHUMANN (1886, 1890). Thus, KuNTH (1822), working with the Humboldt and Bonpland collections, recognised two 'sections' in Bombax: "filamente quinque" for his Bombax aesculifolia, and "filamenta creberrima (Ceiba)" for two other species with multiple stamens. Kunth (1822) also described the genus Chorisia for two species, $C h$. insignis and $C h$. crispiflora, with complete fusion of the functional staminal filaments to give a tube around the style, but he recognized that this was a complex structure: “... tubus staminens duplex; interior tenuis, elongatus, teres, apice antherifer; exterior brevis, interior adnatus, apice decimolobus, lobis patentibus, sterilibus. Antherae 10, sumo tubo externae adnatae...". 
De CANDOLle (1824) retained Bombax for seven species with multiple stamens, and Chorisia for Kunth's two species, but he described the genus Eriodendron (with Ceiba Plum. as a synonym) for species with five free staminal filaments united at their base into a tube, to which he referred Bombax aesculifolium, Bombax erianthos (as E. leiantherum) and Bombax pentandrum (as E. anfractuosum). To these latter genera, NEES \& MARTIUS (1823) added Chorisia ventricosa, MARTIUS \& ZUCCARINI (1826) Eriodendron samauma, and SAINT HILAIRE (1828) described Chorisia speciosa, Eriodendron pubiflora and $E$. jasminodora.

Additional generic names were subsequently proposed by diverse authors but none received widespread acceptance, and the modern view of Ceiba and related genera was cast by SCHuMANN in his treatment of the group for Martius's Flora brasiliensis (1886) and subsequently his monograph in Engler and Prantl's Pflanzenfamilien (1890). In the tribe Adansoniae Benth., Schumann recognized four genera: Adansonia, Bombax, Chorisia and Ceiba. The broadly based Bombax recognized here was subsequently split by various authors, most notably by ROBYNS (1963). Schumann (1890) recognized Ceiba with three sections: sect. Campylanthera with four species from tropical America including $C$. samauma and $C$. pentandra, sect. Eriodendron, with one very different species, $C$. rivieri (now at Spirothera), and sect. Erione, again with a disparate group of taxa including $C$. rosea from $C$ America, and C. pubiflora and $C$. jasminodora from Brazil. Except for recognition of the genus Spirothe$c a$ by ULBRICH (1914), which involved the transfer of Ceiba rivieiri to this new genus, Schumann's view of the genera Ceiba and Chorisia has remained essentially intact until the proposal to unite these genera by GIBBS \& al. (1988).

Our reasons for this proposal are discussed in detail in the paper cited above. Essentially they are based on the fact that the diagnostic character between Chorisia vs. Ceiba, viz. that species of the former have a lower stami- nal tube with a corona-like structure of staminal appendages, and with the upper staminal filaments fused to form a tube, whilst species of Ceiba, lack such appendages and divide to give 5 filaments, in fact breaks down with intermediate conditions. Strictly applied, the distinction between Chorisia and Ceiba leads to such species as Chorisia speciosa and the closely related (and interfertile) Ceiba pubiflora, and similarly, Chorisia glaziovii and the closely related Ceiba erianthos, being placed in separate genera, as DAwson (1944) and SANTOS (1964) noted. We have also produced fertile hybrids between Ceiba erianthos $\times$ Chorisia speciosa and C. erianthos $\times$ Chorisia chodatii. Again as discussed by GIBBS \& al. (1988), pollen morphology divides these taxa not according to Chorisia vs. Ceiba, but a large group of both these genera, with essentially peritreme grains, are distinct from some four or so species with distinctly oblate grains. We used this striking pollen difference to recognize two sections with the united genus Ceiba.

The taxonomy of Ceiba presents some special problems. Most species flower in the leafless condition so that many specimens are either of flowers or leaves. Many Ceibas are large forest trees with flowers of difficult access, so that often specimens have been prepared from old fallen flowers collected on the forest floor. Moreover, since many species have crepuscular or nocturnal anthesis, so that flowers collected after midday the following day are already entering senescence. Add to which most species have fleshy flowers with delicate colour variations which, if not dried carefully, e.g. using aluminum corrugates and heated presses, lose their colour and partially their form. These comments are not made to excuse poor taxonomy, but rather to plead for careful future collecting with this group, and to stress the value of colour photos, and perhaps to justify the rather broad approach we have taken with several species, e.g. $C$. aesculifolia, and $C$. pentandra. It will be surprising if our treatment will represent the last word on these taxa. 


\section{MATERIALS AND METHODS}

This revision is based on herbarium specimens from the following herbaria: $\mathrm{BAB}$, BAF, BHCB, BRAD, CAS, CEN, CEPEC, COL, CPAP, DS, E, EAC, ESA, F, FHO, G, GUA, HUEFS, HXBH, INPA, IPA, K, LIL, LL, MBM, MO, NY, OXF P, R, RB, S, SJRP, SP, SPF, TEX, U, UEC, US, WIS, although we have not necessarily seen all material in any particular herbarium. Where possible we have also studied species either in the field (C. glaziovii, C. jasminodora, C. pubiflora, C. speciosa), or in arboreta (C. erianthos, C. samauma).

\section{MORPHOLOGY}

\section{Growth habit}

All ceibas are trees, commonly 5-20 m but in some species with imposing height, e.g. Ceiba pentandra, at $30-50 \mathrm{~m}$, is a canopy emergent of the varzea forest in Amazonian Brazil and riverine forest in W Africa. This species may also present well developed buttresses. At the other extreme, C. jasminodora is often encountered as a treelet of $1.5-2 \mathrm{~m}$ in upland, rocky campo rupestre habitats in Minas Gerais. Most ceibas present aculeate spines on trunk and branches, and in some species (particularly C. chodatii, C. pubiflora, $C$. speciosa of the $C$. insignis agg.) the trunk may be markedly ventricose (hence the common names barriguda, palo borracho) but individuals of the same species may vary with respect to spines and trunk form.

\section{Leaves}

All species have digitate leaves, commonly 5-7 foliolate, usually with a long, slender petiole and diminuitive petiolules, commonly more or less lanceolate, chartaceous to coriaceous, with margin entire or dentate. Serration of the margin may be variable within species, but is consistent in e.g. the aptly named $C$. aesculifolia, and consistently absent in e.g. C. erianthos, C. jasminodora, $C$. samauma and $C$. schottii. Again, $C$. jas- minodora is distinctive in having 3-foliolate leaves, usually with a distinct mucron. Indumentum, when present, of simple or stellate hairs, sometimes varying between individuals of the same species.

\section{Calyx}

Usually more or less campanulate, robust to fleshy, usually glabrous externally (with few exceptions, particularly some specimens of $C$. aesculifolia, and $C$. soluta) and densely villous within, opening to give 4-5 irregular lobes. Dispersed nectaries are distributed on the inner surface of the calyx.

\section{Corolla}

Commonly with 5 rather fleshy, more or less linear-oblong to spathulate petals which may be held erect to give a funnelform (C. chodatii) or more or less campanulate (C. boliviana) flower, but in most species with petals spreading, and in some e.g. C. jasminodora, C. aesculifolia, markedly reflexed.

Petal colour and markings are important characters in this genus, although usually lost with herbarium specimens (for which, in many cases, the flowers have been collected after having fallen to the ground), and sparingly commented upon by collectors, making colour photographs invaluable for understanding the species. A common feature is for the petal limb, whether white, ivory or pink to magenta in colour, to have distally sparse dark, usually deep carmine, flecks or striations, which may merge below, but with the claw pale yellow. Thus, $C$. boliviana has strikingly profuse and anastamosing carmine striations on a white-pink petal background, whilst $C$. pubiflora is very variable in this respect, ranging from delicate pale pink petals with few flecks, to dense pink-lilac with many dark striations which may merge below. The ivory-pale yellow petals of $C$. chodatii present very few flecks. The white petals of C. glaziovii present variable carmine flecks or striations, whilst the whitish petals of $C$. erianthos have a conspicuous central carmine zone. The petals of our new species $C$. lupuna are a uniformly dense red, with the usual yel- 
low claw, whilst those of the morphologically rather similar $C$. speciosa and C. crispiflora have magenta petals with sparse carmine flecks or striations. In old or badly pressed specimens, Ceiba flowers of diverse species appear yellowish brown with dark brown markings, and the yellow claw becomes white.

In most species, the petals are shortly sericeous pubescent externally and mostly glabrous within, although the distal inner surface may also have hairs, especially towards the margins. In the species of sect. Campylanthera (the $C$. aesculifolia complex, $C$. schottii) this external pubescence has a tan colour, whilst in $C$. erianthos and $C$. boliviana the petals are notably white villous-tomentose externally.

\section{Androecium}

The androecium in Ceiba species provides important characters. Superficially, in most species, seemingly five stamens are united by their filaments to form a lower tube, which surrounds the pistil, and which then splits to give five separate filaments and anthers. The situation is structurally much more complex, and reflects the amazing diversity of stamen filament-anther fission and fusion in the Malvales as partially documented in the study by VAN HEel (1966).

Based on histological sections and cleared tissues (clearing the androecium with concentrated $\mathrm{KOH}$-fuchsin solution, which provides translucent tissues with deeply staining veins, was particularly helpful) our interpretation of the androecium in Ceiba species is as follows. Two whorls with (internally) 5 and (externally) 10 filaments are present. In the lower staminal tube which is present in all species, these are represented by 15 vascular traces in five groups of three. In species of the $C$. insignis agg., which possess a distinct "coronalike" whorl of five bifid, staminal appendages, each appendage receives a curved deviation of the outer two vascular traces, which then rejoin the central traces to ascend the upper staminal tube, and enter the collar of "five" seemingly bithecate anthers. These ac- tually derive from 15 monothecal anthers, each with the interior thecum reduced to connective tissue. In species which have five free stamen filaments above the level of the staminal appendages (or the vestiges of these), each filament presents three fused vascular traces, and an "anther" with two functional thecae, again with the central thecum reduced to connective tissue. In $C$. trischistandra, the triple nature of the staminal filaments is revealed as each "filament" finally divides to furnish three monothecate anthers. In $C$. soluta such fission extends to the level of the staminal "corona" to give 15 staminal filaments, although the actual number seems to be variable in the few specimens available.

In $C$. glaziovii the staminal appendages are not bifid, whilst in $C$. erianthos they are represented merely by a hairy swelling, as SANTOS (1964) noted and illustrated. In other species of sect. Ceiba, the staminal appendages may form a disc-like structure (C. jasminodora), or a truncate ledge (C.pentandra). In species of sect. Campylanthera, the staminal appendages in $C$. aesculifolia and $C$. soluta lack a vascular loop, and are absent (or represented by an "articulation") in C. schottii.

\section{Fruit and seeds}

In all species the fruit is a rotund to ellipsoidal, 5-valvate capsule, with a mostly smooth exterior, and in which the endocarp develops into a white cotton-fibered mass (hence common names "painera", "pochote") which surrounds the many seeds. When the capsule valves fall away, this cottony kapok aids in the wind dispersal of the entangled seeds. Seeds are round to pyriform to reniform, usually largish, $5-10 \mathrm{~mm}$, with testa dark brown to black, with matt to smooth surface.

\section{Cytology}

BAKER \& BAKER (1968) reported chromosome numbers for diverse genera of the Bombacaceae, including Chorisia speciosa $(=\mathrm{Ce} i$ ba speciosa) with $2 n=72$, and 26 counts for 
C. pentandra s.l. of $2 n=72-88$, from provenances in Jamaica, Guyana, W Africa and Indonesia. All counts were with root tip material, either from acetocarmine squash preparations, or haematoxylin stained sections. $\mathrm{Da}$ Cruz (GIBBS \& al., 1988), using aceto-orcein squash preparations of anther material, established chromosome numbers of $n=43$ for Ceiba insignis, C. erianthos, C. glaziovii, C. jasminodora, C. pentandra, $C$. pubiflora and $C$. speciosa. Interestingly, da Cruz noted that root tips of germinating seeds of $C$. speciosa gave counts of $2 n=69-87$ showing that aneusomatic divisions may occur, and perhaps explaining the cytological variation reported by BAKER \& BAKER (1968). These consistent counts of $n=43$ for Ceiba species, contrasted with counts of $n=46$ for Pachira aquatica Aubl., $n=44$ for Bombax longiflorum (Mart. \& Zucc.) K. Schum. and $n=46$ for Spirotheca passifloroides Cuatrec.

\section{REPRODUCTIVE BIOLOGY}

Most Ceiba species have nocturnal anthesis and C. pentandra (GRIBEL \& al., 1999) and $C$. erianthos (observations by $\mathrm{J}$. Semir) are known to be bat-pollinated. This also likely to be the case in $C$. glaziovii, $C$. boliviana, $C$. insignis, C. samauma, $C$. ventricosa, and C. trischistandra, but field observations are lacking. C. erianthos and C. glaziovii have particularly copious nectar. $C$. chodatii also has crepuscular anthesis but with sparse nectar, and is probably pollinated by sphingid moths (we have seen sphingids visiting flowers of cultivated trees in Rosario, Argentina), as may be the case with $C$. jasminodora and $C$. schottii. C. speciosa (and probably C. crispiflora) is pollinated by diurnal butterflies which beat their wings against the anthers or stigma as they probe between the staminal appendages for nectar. Hummingbirds are frequent but ineffective visitors to this species since they do not touch the anthers/ stigma. However, C. pubiflora. with its resupinate anthers and somewhat more copious nectar, seems to be adapted for pollination by humming birds, which are certainly frequent visitors to its flowers. It is notable that the corona-like staminal appendages, when they occur, serve to restrict access to the nectar. Thus they are present in all moth, butterfly or hummingbird pollinated species, but absent or reduced in most, but not all, bat or potentially bat-pollinated species.

The Bombacaceae present a cluster of taxa [see GIBBS \& BIANCHI (1999) for review] with late-acting self-incompatibility (LSI) sensu SEAVEY \& BAWA (1986). In this system, selfed flowers uniformly fail to form fruits although self pollen tubes grow to the ovary and penetrate ovules. In the genus Ceiba, LSI has been studied in the species $C$. chodatii and C. speciosa (GIBBS \& BIANCHI, 1993) and C. pentandra (GRIBEL \& al., 1999).

\section{HabitaT}

Most species of Ceiba are restricted to seasonally dry woodlands, including $C$. erianthos, which occurs in the coastal restinga of SE Brazil, but almost always associated with rocky outcrops, as is $C$. jasminodora in the "campos rupestres" of Minas Gerais. C. pubiflora seems to have a marked but not exclusive preference for calcareous soils in its distribution from Mato Grosso Sul to the caatingas of northern Minas Gerais and Bahia. However, some species, such as $C$. samauma and $C$. speciosa, seem to be able to occupy both dry seasonal forest and humid river valleys, whilst $C$. pentandra shows even greater tolerance, occurring in seasonally flooded lowland forest in Amazonia, but also in mesic habitats in Central America. This same tolerance seems to apply to $C$. pentandra in West Africa, where BAKER (1965) reported it to be rare in evergreen rain forest but very common in moist, semideciduous forests, and commented: "it is a common constituent of the gallery forests which line the river banks as these lead out from the true forest into the savanna woodlands and the true savannas". As far as we are aware. only C. lupuna occurs exlusively in humid forest. 


\section{TAXONOMY}

Ceiba Mill., Gard. Dict. Abr. ed. 4 (1754)

Chorisia Kunth in Humb., Bonpl. \& Kunth, Nov. Gen. Sp. 5: 295 (1822)

Eriodendron DC., Prodr. 1: 479 (1824)

Xylon Kuntze, Revis. Gen. Pl. 1: 74 (1891)

Xylum T. Post \& Kuntze, Lex. Gen. Phan., Prosp. 598 (1903)

Type: Ceiba pentandra (L.) Gaertn. (lectotype, designated by NiCOLSON, 1979).

Trees, in some species of considerable size, and sometimes with a ventricose trunk, both trunk and branches often with stout aculeate spines. Leaves alternate, compound-digitate, with a longish petiole, with 3-5(8) leaflets; leaflets elliptic, lanceolate, or oblanceolate, serrate or entire, usually attenuate, acute to acuminate, rarely obtuse; both surfaces usually glabrous, occasionally sparsely simple or stellate hairy. Inflorescences in few-flowered fascicles or flowers solitary, with very caducous bracts and bracteoles. Flowers 18 $145 \mathrm{~mm}$, with 5 usually spreading or sometimes funnelform or campanulate petals. Pedicels usually stout. Calyx thick-fleshy, campanulate, opening irregularly to give 3-5 lobes, externally usually glabrous, internally densely villous-pubescent, with dispersed nectaries over the internal surface. Petals connate to the staminal tube at the base, usually oblong-spathulate, with entire or undulate margin, usually mostly glabrous internally, sparsely to densely whitish to brownish sericeous externally, white to pinkish to magenta or red, usually with the claw yellowish, limb with inner surface frequently blotched with carmine striations. Staminal filaments fused to form a tube around the ovary, sometimes with a corona-like whorl of staminal appendages. Staminal tube usually dividing to give five free filaments; but in some species these filaments remain fused above the staminal appendages to give an upper staminal tube (insignis agg.), whilst in two species, the five initial filaments split to give three filaments terminating in monothecate anthers: in C. trichistandra this division occurs in the upper part of the common filament, whereas in
C. soluta it occurs just above the staminal appendages. The ovary superior, usually pyriform, five loculate-carpellate, with axile placentation and many ovules. Style usually slender, white and glabrous (hairy in $C$. samauma), terminating in a globose somewhat lobed stigma, which may be white to red. Fruit an elongate capsule with the seeds embedded in dense cotton-downy fibres originating from the endocarp. Seeds large, 5$10 \mathrm{~mm}$, roundish to pyriform to reniform, dark brownish-black.

Three species occur in Mexico and Central America, and 13 species are distributed in South America. $C$. pentandra is the only species which extends outwith South-Central America and the Caribbean Islands, occurring in W Africa, where it is probably native, and also in India, SE Asia and the Pacific, to which areas it was most likely introduced by man.

\section{KeY TO SPECIES OF CEIBA}

1. Flowers with 10-15 free staminal filaments, variously united below

- Flowers with 5 free staminal filaments, united below, or all filaments fused for their entire length (occasionally some fission terminally) to form a tube

2. Calyx crimson, with whitish hairs; short staminal tube giving rise intially to 5 filaments, which further subdivide to give 3 free filaments 12. C. trischistandra

- Calyx greenish brown, with orange-brown hairs; short staminal tube bearing 10-15 slender staminal filaments 17. C. soluta

3. Lower staminal tube lacking appendages ...... 4

- Lower staminal tube with appendages in the form of a disc, or 5 very hairy linear scales, or a corona-like whorl of 5 (usually bifid) short appendages 7

4. Petals less than $50 \mathrm{~mm}$; staminal column 5$14 \mathrm{~mm}$ 13. C. pentandra

- Petals more than 65-220 mm; staminal column $10-100 \mathrm{~mm}$ 5

5. Anthers markedly anfractuose; style densely hairy as it emerges from staminal tube, becoming glabrous above 14. C. samauma

- Anthers sinuous with undulate thecae; style entirely glabrous 
6. Petals $65-90 \times 18-22 \mathrm{~mm}$, broadly spathulate, with dense, white-lanate exterior; lower staminal column 10-20 mm, rather swollen below the 5 free filaments, densely hairy

10. C. erianthos

- Petals 170-190 × $15 \mathrm{~mm}$, narrowly oblong, with short, brownish sericeous hairs exteriorly; lower staminal tube $80-100 \mathrm{~mm}$, slender, sparsely hairy 15. C. schottii

7. Leaves 3-foliolate; petals $18-25 \mathrm{~mm}$; lower staminal column terminating in a disc-like staminal appendage giving rise to 5 free, $8-12 \mathrm{~mm}$ stamen filaments ............ 11. C. jasminodora

- Leaves mostly 5-7 foliolate; petals $50 \mathrm{~mm}$ or more; lower staminal column terminating in scale-like or corona-like staminal appendages, giving rise to an upper staminal tube, or 5 free staminal filaments, of $50 \mathrm{~mm}$ or more .8

8. Flower with fused staminal filaments which form a tube terminating in a collar of 5 anthers (occasionally some terminal fission of this tube) ........ C. insignis agg. (key at page 267)

- Flower with 5 free filaments arising from a 10$50 \mathrm{~mm}$ lower tube

.9

9. Lower staminal tube bearing 5 densely hairy scale-like appendages; petals usually markedly reflexed. 16. C. aesculifolia

- Lower staminal tube bearing 5 short, usually bifid, appendages which close off the lower corolla; petals erect or spreading .10

10. Flower more or less campanulate with petals held erect; petals whitish coloured with dense dark red reticulating striations; stamen filaments deep red, anthers anfractuose; stigma deep red. 8. C. boliviana

- Flower with petals spreading, white or pale pink to pink-lilac, distally with carmine flecks or striations which may fuse below; stamen filaments white, anthers sinuous; stigma white to pale pink 11

11. Petals pale pinkish, or pink-lilac, distally with sparse to marked dark carmine coloured striations which may fuse below; stamens resupinate; with diurnal flowering

7. C. pubiflora

- Petals white distally, dark livid towards the base internally; stamens spreading; with nocturnal flowering 9. C. glaziovii

\section{Ceiba sect. Ceiba}

Ceiba sect. Erione K. Schum. in Engl. \& Prantl (eds.), Nat. Pflanzenfam. 3(6): 63 (1890)
Type: lectotype, here designated, C. pubiflora (A. St.-Hil.) K. Schum.

Pollen peritreme, spherical to oblate-spheroidal with medium to high, simple or branched bacula supporting sinuous muri. Staminal appendages, when present, vascularized.

\section{Ceiba insignis aggregate species}

Trees c. $12 \mathrm{~m}$ or more with sometimes swollen, usually aculeate trunk. Leaves 5-7 foliolate, petiole $35-80 \mathrm{~mm}$ long; leaflets 35 $110 \times 17-50 \mathrm{~mm}$, oblanceolate or elliptical, with apex acuminate, margin entire or variously denticulate, glabrous, petiolules 5$15 \mathrm{~mm}$ long. Inflorescence essentially corymbose but with flowers borne in fascicles, or pairs, or singly towards the ends of young branches. Pedicels 5-20 mm long. Calyx 20$30 \times 17-25 \mathrm{~mm}$, campanulate, lobed, glabrous externally, usually densely villous within. Petals 60-130 × 6-27 mm, narrowly spathulate to narrowly oblong, usually softly hairy externally, glabrous or nearly so internally, whitish or flushed pink, or magenta to deep red distally, often with darker flecks or striations, and yellow towards the base. Stamens with a basal tube which surrounds the ovary, 10-15 mm long, with a 5 lobed staminal appendages which close the 'throat' of the corolla, the lobes bifid, glabrous to densely hairy, and then a staminal tube extending some $40-100 \mathrm{~mm}$, bearing a collar of 5, 2-thecate, sinuous, usually pale yellowish anthers (except $C$. pubiflora which has 5 free filaments). Ovary superior to slightly inferior, subglobose to pyriform, glabrous, with style usually exserted by some $3-5 \mathrm{~mm}$ (occasionally up to $15 \mathrm{~mm}$ ) above the anthers and with a white or reddish, globose stigma. Fruit and ellipsoidal-pyriform capsule, c. 10-15 × 8$10 \mathrm{~cm}$.

We group the following sequence of seven species in an aggregate species sensu HEYwoOD (1963): “... the aggregate is a device employed to group together for convenience a number of species (binomials). The component binomials are in taxonomic terms close- 
ly related and difficult to discriminate. Their distinguishing characters, although less pronounced and perhaps fewer in number than those which serve to distinguish between other species, are, however, constant and the species appear to be effectively isolated from one another". With one exception, the component species of the $C$. insignis agg. are characterized by the presence of an entire staminal tube which terminates in a collar of anthers.

Species of this aggregate extend in a more or less U-shaped arc of semi-deciduous vegetation from NE-SE-SW Brazil, Paraguay, the Argentine piedmont area as far south as Tucumán, Bolivia, and NW Peru to S Ecuador. This kind of distribution parallels that of the "Pleistocenic Arc" of seasonal woodlands as defined by PRADO \& GibBs (1993), PENNINGTON \& al. (2000), but with the complication that whilst most of the species of the $C$. insignis agg., e.g. C. insignis s.s., C. chodatii, $C$. incana and C. pubiflora, and $C$. ventricosa are certainly resticted to seasonally dry habitats, the widely distributed $C$. speciosa and also C. lupuna, can be found in moist riverine forest in Peru and in W Brazil (Acre, Rondônia).

One species referred to this aggregate, C. pubiflora, has free stamens. This species occurs from Paraguay to centre-west-NE Brazil (Mato Grosso, Goiás to Minas Gerais and Bahia), especially on calcareous soils. Ceiba pubiflora shares the prominent coronalike staminal appendages of the $C$. insignis agg. but either immediately, or some $5-10 \mathrm{~mm}$ above the corona, five separate staminal filaments diverge. It is likely that all members of the $C$. insignis aggregate are interfertile. Certainly $C$. speciosa $\times C$. chodatii form fertile hybrids, some of which are commonly cultivated as street trees in Argentina, and C. pubiflora $\times$ C. speciosa can also cross. Moreover, occasional specimens of $C$. speciosa and C. chodatii are encountered with flowers with the upper staminal tube partially split to give five filaments with separate anthers. Howev$\mathrm{er}$, it is notable that the component species diverge in timing of anthesis, and as a consequence, pollinator type.

\section{KEY TO SPECIES OF CEIBA INSIGNIS AGG.}

1. Stamens with 5 free, usually resupinate filaments arising directly from, or some $5-10 \mathrm{~mm}$ above, the staminal appendages 7. C. pubiflora

- Stamens above the staminal appendages united into a tube which has a collar of 5 sinuous, anthers (occasionally this tube with some fission distally and so anthers free)

2. Petals ivory to pale yellow, whitish, or white suffused pink

- Petals deep pink-magenta, or red, at least distally ......

3. Flower rather funnel-form with ivory-pale yellow petals held erect, staminal appendages whitish, glabrous 6. C. chodatii

- Flower rather stellate with the white to whitepinkish petals spreading, staminal appendages usually hairy

4. Petals narrowly spathulate or oblong, with only slightly undulate margin, white to suffused pink distally, yellowish towards the base; staminal tube below the staminal appendages pale and glabrous, staminal appendages white or reddish. glabrous to sparsely hairy $\ldots 1$. C. insignis

- Petals narrowly oblong with markedly undulate-crespate margin, whitish with dark reddish flecks distally, these merging towards the base; lower staminal tube reddish and cinerous sericeous, staminal appendages dark red, densely hairy 5. C. ventricosa

5. Petals uniformly deep red distally, pale yellow at the base 2. C. lupuna

- Petals deep pink-magenta distally, with many dark red striations mid-length, pale yellow towards the base

6. Staminal tube below the staminal appendages glabrous: petals rather spathulate or broadly oblong, usually more than $15 \mathrm{~mm}$ wide, margin only slightly undulate 3. C. speciosa

- Staminal tube below the staminal appendages sericeous; petals narrowly oblong, usually less than $15 \mathrm{~mm}$ wide, with markedly undulate-crespate margin 4. C. crispiflora

1. Ceiba insignis (Kunth) P.E. Gibbs \& Semir, Notes Roy. Bot. Gard. Edinburgh 45: 134 (1988)

Chorisia insignis Kunth in Humb., Bonpl. \& Kunth, Nov. Gen. Sp. 5: 297, tab. 485 fig. 1 (1822), non $C$. insignis auct.

Ind. loc.: "Crescit ad ripam flumis Amazonum prope Tomependa, Chamaya etc." 
Type: Peru? specimen without locality, Humboldt \& Bonpland s.n. (lectotype, here designated, P!)

Chorisia integrifolia Ulbr., Bot. Jahrb. Syst. 54, Beibl. 117: 77 (1916); Ceiba integrifolia (Ulbr.) Ravenna, Onira 3: 46 (1998)

Ind. loc.: "Peru. Cajamarca: near Jaen, in fruticetis et fruticibus peraltis arboribusque parvis compositis in altitudine $900 \mathrm{msm}$ "

Type: Peru. Cajamarca, Jaén, IV-1912, Weberbauer 6195 (lectotype, here designated, US-digital image!)

Trees c. $10 \mathrm{~m}$, usually with aculeate trunk. Leaflets somewhat coriaceous, entire or denticulate. Pedicels $15-25 \mathrm{~mm}$ long. Petals 90 $120 \times 22-25 \mathrm{~mm}$, spathulate to narrowly oblong, with only slightly undulate margin, white sericeous to villous externally, glabrous internally, white to pale pink, sometimes with occasional dark reddish striations, with a yellowish zone from mid-length to the base. Staminal tube glabrous below the appendages; the appendage lobes whitish or orange-red, glabrous to sparsely hairy, upper staminal tube glabrous, flushed pink, sometimes splitting distally to give 5 short filaments. Stigma red. Fruit ellipsoidal or pyriform capsule.

Flowering May-July(October). Dry valleys with semi-deciduous woodland. S Ecuador (Loja) and N Peru (Amazonas, Cajamarca, Piura, and San Martín) (fig. 1).

This species has a problematical history, not least because in 1900 Hicken identified trees of $C$. chodatii cultivated at La Recoleta in Buenos Aires as Chorisia insignis HBK, and largely as a consequence, the name $C$. insignis has been widely given to specimens collected in Argentina, Bolivia and Peru as well as to cultivated trees, giving rise to considerable taxonomic confusion. We here identify $C$. insignis s.s. with a white-pinkish flowered species of dry, deciduous woodland in NW Peru-Ecuador. We base our view on the following considerations.

Rather than cite type material, Kunth (1822) simply gave a terse summary of the distribution of known localities and collections: "Crescit ad ripam flumis Amazonum prope Tomependa, Chamaya etc". Chamaya, $\left(5^{\circ} 44^{\prime} \mathrm{S}, 78^{\circ} 39^{\prime} \mathrm{W}\right)$ in N Peru, is near the junction of the river Chamaya with the river Marañón, somewhat between Jaén and Pucara, the latter both dry woodland areas. Tomependa has never been precisely located, but SANDWITH (1968), in his account of the Humboldt and Bonpland travel itinaries, listed it in their sequence of travels between Passo de Pucara-Las Huertas-Passo de MataraPasso de Cavico-Sonanga-Chamaya-Choros ( $\left.5^{\circ} 52^{\prime} \mathrm{S}, 78^{\circ} 40^{\prime} \mathrm{W}\right)$-Tomependa-Río Chinchipe to Río Marañón.

In the Humboldt and Bonpland collections at $P$ there is only one specimen referable to C. insignis which surprisingly does not have a locality but simply bears (apparently in Kunth's hand by comparison with examples in BURDET, 1976, p. 145) the name "Chorisia insignis". It is very likely that this specimen in Paris, which has the flower dissected with calyx, staminal tube and individual petals displayed, as well as leaves, provided the basis for the illustration of Chorisia insignis of the protologue, and we therefore have no hesitation in choosing it as the lectotype of $C$. insignis. However, from the reference to a fruit in his description, Kunth evidently also had access to either additional specimens, or to Bonpland's notes on this taxon.

Based on specimens from the the Chamaya-Tomependa area, $C$. insignis is a species of semi-deciduous woodlands in dry valleys which has whitish-pink flushed flowers. SChumann (1886), in his description of Chorisia insignis in Martius' Flora Brasiliensis, repeated the Chamaya and Tomependa localities but added a Spruce collection from Tarapoto, some $250 \mathrm{~km}$ to the East, in San Martín province. Since duplicates of this collection were widely distributed, it comprises an important source for $C$. insignis s.s. but cannot of course be considered as type material. Despite its location in the upper valley of the Rio Huallaga, the Tarapoto area is a noted enclave of savanna vegetation where even some Brazilian cerrado species are found (pers. comm., T.R. Pennington) so that it is perhaps not surprising that $C$. insignis, essentially a dry woodland species of the $\mathrm{W}$ side of the 


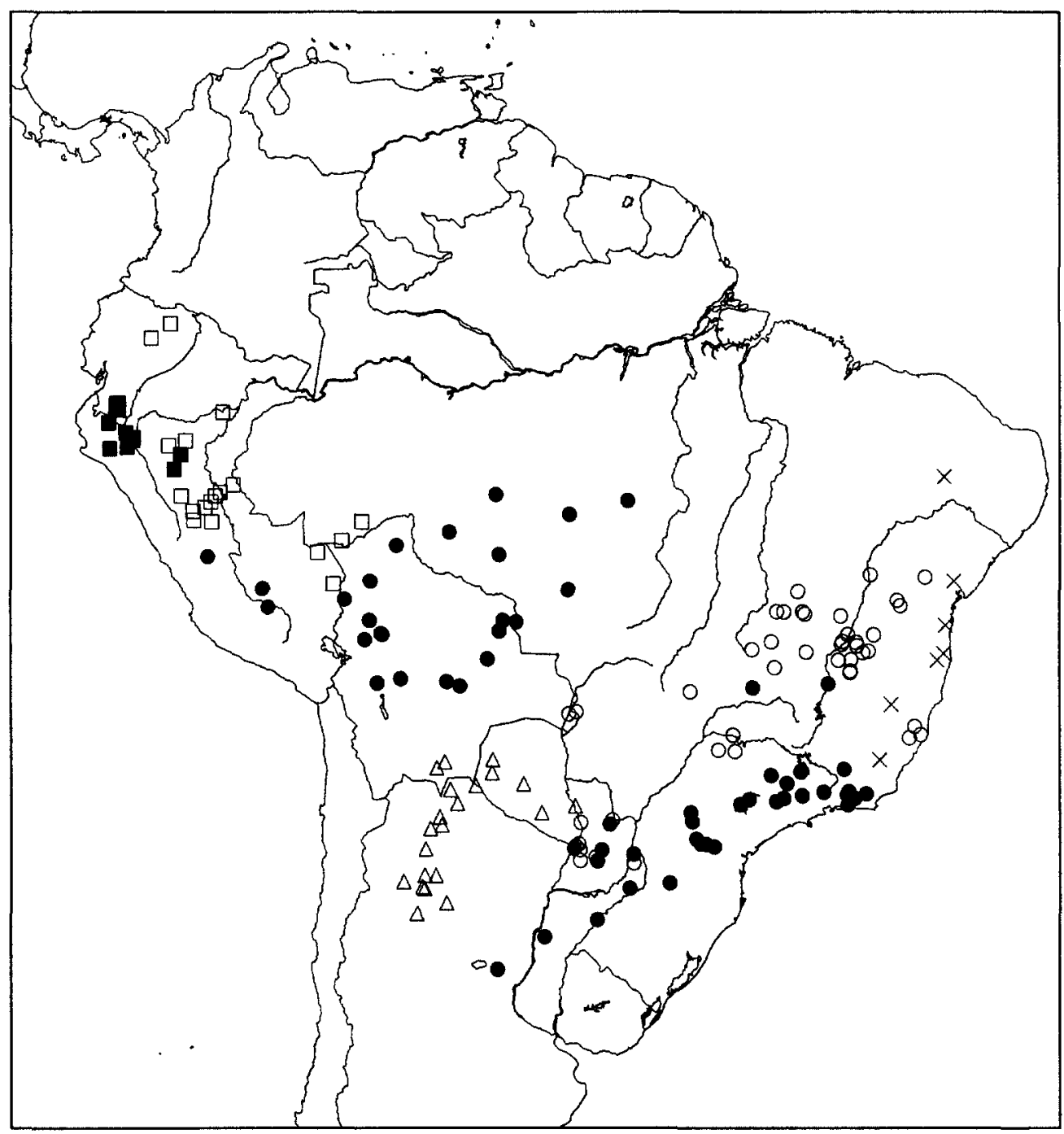

Fig. 1.-Distribution map of Ceiba insignis agg.: $\triangle C$. chodatii, $\square$ C. insignis, $\square$ C. lupuna, $\bigcirc$ C. pubiflora, $\bigcirc$. speciosa, $\times$ C. ventricosa.

Marañón river system, also occurs there. The Spruce 3928 Tarapoto specimen at $\mathrm{K}$ has a more extensive label than most duplicates of this collection, and states "flores rosei" and that the plants occurred in "praeraptis saxosis". Although some labels refer to the flowers of $C$. insignis from Ecuador and Peru as simply 'white', the photos of this species by Lewis (collection Lewis \& al. 3308, near Catamayo, Ecuador), and also that of Gentry (Gentry \& al. 22688 near Pucara, in NW
Peru) show petals with a distinct pinkish tinge. There is no great problem therefore in including the Spruce Tarapoto collection in C. insignis s.s., despite its occurrence at a site well to the $E$ of the Marañon river, and reference to 'pink' flowers.

In RAVENNA's (1998) key to five species of Ceiba, C. insignis was keyed out together with $C$. speciosa as: "Corolla pink to bright purple-pink", and then distinguished from C. speciosa with a series of vegetative charac- 
ters ranging from mature tree height $45 \mathrm{~m}$ (insignis) vs. $25 \mathrm{~m}$ (speciosa), and "thorns not perfectly conical, oblique or curved, 30$55 \mathrm{~mm}$, leaf margins repand, or teeth diminutive, less than $1 \mathrm{~mm}$. Anthers 4-5 mm" (insignis) vs. "thorns perpendicular to bark surface, perfectly conical, 8-15 mm. Leaflets coarsely dentate, teeth oblique 1-3 mm. Anthers 7$8 \mathrm{~mm}$." (speciosa). This interpretation of C. insignis is obviously at variance with that outlined above. However, since no exsiccata were cited it is difficult to understand Ravenna's concept of this species.

Chorisia integrifolia is another problematical taxon. Ulbrich described his species as having 'white flowers', and the type specimen is a Weberbauer collection from near Jaén (Catamarca), which is close to the type locality of $C$. insignis at Chamaya, and other localities of 'white-pinkish flowered' $C$. insignis collections at Pucara by Gentry. Ulbrich's insistence on the diagnostic entire-margined leaves for his $C$. integrifolia is unhelpful since entire to minutely denticulate margined leaves are common in $C$. insignis s.s and other taxa of this aggregate. We therefore refer Chorisia integrifolia to C. insignis s.s.

RavenNa (1998) reported seeing trees of C. integrifolia between Pucara and Jaén but was apparently unaware that this locality is close to the type locality of $C$. insignis, or that this latter species is also characteristic of the "dry montane plains of the province of Jaen" to which he refers $C$. integrifolia. Unfortunately, RavenNa (1998) did not include $C$. integrifolia in his key to species of the $C$. insignis group, so that his interpretation of this species is again uncertain.

Ulbrich also subsequently identified a collection by Raimondi from Junín: Chanchamayo to his $C$. integrifolia. Whilst this specimen certainly has entire-margined leaves, the narrow petals with undulate margins are similar to those of the red-flowered $C$. lupuna (see below), and the locality on the Rio Mantaro is also in accord with this. We therefore refer this Raimondi specimen to $C$. lupuna.

It seems likely that $C$. insignis flowers open at dusk (various photos show pollen dusted on the inner surface of the petals indi- cating pollen liberation before petal opening) and if so with crepuscular or nocturnal pollinators, but no collection details or field observations are available.

\section{Examined specimens}

ECUADOR. LOJA: Catamayo to Puerte Boquerón, 9-X1955, E. Asplund 18089 (G, LL. NY, P, S). Gouzanama to Catamayo, km 23, 15-V-1997, G. Lewis, B. Merino \& P. Lozano 3308 (K). Hacienda Comunidades, S. Vilcabamba, 14-V-1967, B. Sparre s.n. (S). Loja, 5-VI1946, R. Espinosa 523 (NY). Malacatos, $25 \mathrm{~km} \mathrm{~S} \mathrm{of} \mathrm{Loja,}$ 9-VII-1944, W. Camp 124 (NY); ibidem, 10-VII-1959, G. Harling 5784 (NY); c. $12 \mathrm{~km}$ W of Catamayo, 14-VII1989, J. Dorr \& I. Valdespino s.n. (K),; $20 \mathrm{~km} \mathrm{~S} \mathrm{of} \mathrm{La}$ Toma, 21-23-VII-1959, G. Harling 6067 (NY, S).

Peru Amazonas: $5 \mathrm{~km}$ E of Bagua on road to La Peca, Marañon valley, 12-VI-1978, A. Gentry \& al. 22776 (MO). CAJAMARCA: $97 \mathrm{~km}$ E of Olmos on road to Pucará, 11-VII-1986, T. Plowman \& al. 14227 (F). Mandanguia, 3-X-1961, F. Woytkowski 6817 (MO). Outskirts of Pucará, A. Gentry \& al. 22688 (MO). PIURA: Curilcas, valley of Rio Quiróz, V-1912, A. Weberbauer 6349 (F, WIS). SAN MARTfN: Tarapoto, vii.1855, R. Spruce 3928 (E, F, G, K, NY).

2. Ceiba lupuna P.E. Gibbs \& Semir, sp. nov.

Type: Peru. San Martín, Mariscal Cáceres, Uchiza, 28-III-1972, J.V. Schunke 5326 (holotype, MO!; isotypes, F! G!, NY!, P!, WIS!)

Species quoad characteres praecipuos non dissimilis quidem ab speciebus gregis " $\mathrm{Ceiba}$ insignis aggr." -praesertimque speciebus C. crispifolia et $C$. ventricosa, petalis angustissimis atque margine undulatis insuperque tubo inferiore staminali piloso aliquando-, sed ab speciebus omnibus generis Ceiba floribus aperte rubris modo mirabili differens!

Trees up to $50 \mathrm{~m}$, canopy emergents, trunk and branches usually with blackish aculeate spines. Leaflets somewhat coriaceous, margin entire or denticulate. Pedicels $15-25 \mathrm{~mm}$ long, slender. Petals 50-100 $\times 14-18 \mathrm{~mm}$, narrowly oblong, with markedly undulate margin, deep red distally, pale yellow, speckled red towards the base, externally sericous, drying brownish with whitish pubescence. Staminal tube below the appendages 10-14 mm, glabrous or sparsely sericeous, at least along 
the nerves, appendix lobes dark red, densely hairy. Fruit not seen.

Flowering May-June. Humid forest valleys. Gentry (in litt.) indicated that this redflowered taxon is restricted to nutrient poor soils (see below). Central and E Peru, SE Ecuador (Napo), and W Brazil (Acre, Rondônia) (fig. 1).

In an exchange of letters, the late Al Gentry made the following comments concerning the red-flowered Chorisia which we have here described as Ceiba lupuna: "My big problem concerns what name to put on the red-flowered Chorisia that is common around Pucallpa in Amazonian Peru. We have two species of Chorisia growing sympatrically in this area. One has bright magenta flowers with rather sericeous petals and I am assuming this is correctly called $C$. insignis $\mathrm{HBK}[C$. speciosa on our interpretation]. The other has bright red flowers, black spines on the trunk and has petals when dried more wooly-tannish pubescent outside". Another letter commented: "I recall once flying from Puerto Bermudez to Pucallpa and in the area near Puerto Bermudez seeing both red and pink Chorisia. Nearer Pucallpa there was only the red flowered ones". And with regard to ecology of these taxa Gentry noted: "My guess is that the red and pink flowered species sort themselves out according to soil fertility more than precipitation. The pink flowered form grows in rich soil forests and the red flowered form in more highly leached forests on lateritic soils". This species, with deep red flowers, is most likely to have diurnal anthesis but pollinator type unknown.

\section{Examined specimens}

BrazIL. ACRE: Brasiléia, 11-IX-1991, C. Cid Ferreira \& al. 10.234 (NY); ibidem, 2-VI-1991, D. Daly \& al. 6838 (NY). Rio Branco, estrada Qixada km 15, 10-V1980, L. Coêlho \& al. 1713 (MBM); estrada de Serra Madureira km 22, 13-V-1980, L. Coêlho, C. Simão \& A. Rosas 1761 (NY).

ECUADOR. NAPO: Yasuni, $00^{\circ} 28^{\prime} \mathrm{S}, 76^{\circ} 40^{\prime} \mathrm{W}, 26 / 27-$ VIII-1993, M. Aulestia 367 (MO); $8 \mathrm{~km}$ from Puerto Misahualli, 31-III-1985, D. Neill 6186, A. Suárez \& M. Mecolm S.n. (WIS).

Peru. AMazonas: Rio Acre, V-1911, E. Ule 9597 (G, K, U). Huanuco: Carreterra Pucallpa-Lima, 7-V-1975,
G. Hartshorne, R. Lao \& J. Rios 1669 (MO). Km 12 Pucallpa-Tingo Maria, 31-V-1983, A. Gentry \& N. Jaramillo 41357 (MO, US). Leonicio Prado, near Tingo Maria, 18-V-1962, A. Gutiérrez 58 (F, G, NY, WIS); ibidem, 21VI-1962, R. Lao 18 (F, G, NY, WIS). Puerto Inca, 16-V1986, B. Kröll s.n. (K, WIS). Shapajilla, F. Woytkowski s.n. (F). Junín: Chanchamayo, Raimundi s.n. (F). MADRE DE Dios: Tambopata Nature Reserve, A. Gentry \& $N$. Jaramillo 57497 (MO, WIS). SAN MARTIN: Alonso de Alvarado, carretera a Moyabamba, J. Schunke 5922 (NY). Pampayacu, 4-V-1927, M. Sawada 6 (F). Yurimaguas, Poepig 32192 (F). UCAYALI: Road to Tournavista, $5-15 \mathrm{~km} \mathrm{~S}$ of Pucallpa-Aguaytia, 15-VI-1987, A. Gentry \& C. Diaz 58360 (WIS).

3. Ceiba speciosa (A. St.-Hil.) Ravenna, Onira 3: 46 (1998)

Chorisia speciosa A. St.-Hil. in A. St.-Hil., A. Juss. \& Cambess., Pl. Usuel. Bras., tab. 43 (1827)

Ind. loc.: "In sylvis primaevis provinciarum Rio de Janeiro et Minas Gerais haud infrequens, visa quoque in campis juxta urbem Barbacena, nec nunquam etiam prope domos sativa"

Type: Brazil. Province de Minas Gerais, Saint Hilaire s.n. (lectotype, here designated, P!)

Trees 10-20 m, usually with somewhat swollen, aculeate trunk. Leaflets rather chartaceous, usually serrate. Pedicels $10-15 \mathrm{~mm}$ long rather stout. Petals 70-105 $\times 25-35 \mathrm{~mm}$, spathulate to oblong, externally sericeous, internally glabrous, margin somewhat undulate, dark pink-magenta distally, usually with dark striations midlength, base white to yellow. Staminal tube to the appendages glabrous, appendage lobes usually dark reddish, densely cinerous hairy, sometimes pinkish and glabrous; upper staminal tube white flushed pink, sometimes splitting distally to give 5 short filaments. Stigma white or pinkish. Fruit an ellipsoidal to pyriform capsule, c. 12-18 $\times$ $9-12 \mathrm{~cm}$.

Flowering January-May. Dry semi-deciduous woodland and wet forest. An extensive area from NE and SE Brazil and also $W$ Brazil, N Argentina, Paraguay, Bolivia, $S$ and CPeru (fig. 1). This species is also widely cultivated in Argentina and Brazil as an ornamental.

Illustrations. SANTOS (1964: 168 tab. 3), 
BERNARDINI (1984: 37 fig. 11), LORENZI (1992: 61).

Flowers begin to open at sunrise, and in SE Brazil the early arrival of many honey bees often results in the anthers being cleaned out of pollen by around $10 \mathrm{am}$ and so the flowers are rendered sterile. The effective pollinators of $C$. speciosa observed by us in SE Brazil comprise a series of forest papilionid butterflies which alight on the flower and probe between the coronal lobes for the rather sparse nectar available at the base of the petals. Most of these butterflies, e.g. Battus polydamas (Roths. \& Jord.), Papilio anchisiades (Roths. \& Jord.), P. thoas (Roths. \& Jord.), continue to flutter their wings as they probe the flower, such that these contact either the collar of anthers or stigma. C. speciosa flowers are also visited by humming birds, which mostly fail to contact the anthers, and nocturnal visits by large Phyllostomatus hastatus bats have also been reported by TADDEI (1977).

\section{Examined specimens}

Argentina. Chaco: San Fernando, Resistencia, 19III-1928, A. Muniez s.n. (BAB). CoRrIENTES: $35 \mathrm{~km} \mathrm{SW}$ of Santo Tomé, 5-II-1979, A. Schinini, E. Cabrera \& R. Vanni $I 675 I$ (F, SI); $15 \mathrm{~km}$ E of Corrientes por ruta 12, A. Schinini 14730 (F, MO). MISıNES: Entre Concepción de la Sierra y Puerto San Isidro, 11-III-1969, A. Krapovickas \& al. 15.116 (MBM, MO, WIS). Iguasú, 29-III-1945, M. Bertoni 1987 (F); ibidem, T. Meyer s.n. (F). Itaimbé, 1-II-1935, F. Rodríguez 523 (BAF). San Javier, 12-II-1947, G. Schwarz 4107 (NY). Santa Ana, 20-I-1913, E. Hassler s.n. (BAF); ibidem, F. Rodriguez 729 (F). SANTA FE: Castellanos, Sunchales, E. Autran s.n. (cult?) (BAB).

BOLIVIA. BENI: $30 \mathrm{~km}$ S of Riberalta along Rio Beni, 15-V-1982, J. Solomon 7604 (MO, NY, WIS). Cochabamba: Espírito Santo, 1891, M. Bang 1175 (E, MO, NY). La PaZ: Basin Rio Beni/Rio Tuichi, $1.5 \mathrm{~h}$ upstream from Rurrenabaque, 9-V-1990, D. Daly, $N$. Limpias \& $R$. Sastre 6372 (NY). SANTA CRUz: Along trail from Rio Yapacaní, Parque Nacional Amboro, 31 V-1998, M. Nee \& L. Bohs 49505 (NY). Andrés Ibáñez, 17-IV-1985, P. Bettella 83 (MO). Quinta de Santa Cruz, 31-V-1925, J. Steinbach s.n. (F, MO, NY). Santa Cruz, V-1892, O. Kuntze s.n. (F, NY). Santa Cruz-Abapó. $18^{\circ} 01^{\prime} \mathrm{S}, 63^{\circ} 12^{\prime} \mathrm{W}, 2-\mathrm{V}-1998, M$. Nee 49222 (NY, SI). Without precise locality: Guanai, V-1886, H. Rusby 6612 (NY).

BRAZIL. BAHIA: Rui Barbosa, margem BR242, 50 km depois Itaberaba, 10-III-1981, G. Pinto s.n. (HUEFS) cult?; $40 \mathrm{~km} \mathrm{NW}$ of Vitoria de la Conquista, caatinga. $L$ de Queiroz \& Crepaldi 2160 (HUEFS) cult? MaTo
GRosso: Jauru-Araputinga, 6-V-1995, G. Hatschbach \& al. 62447 (ESA). Nova Bandeirantes-Rolândia, 0950'S, $57^{\circ} 48^{\prime}$ W, N.M. Ivanouska \& al. 2040 (ESA). MATO Grosso SuL: Aripuanã, BR 174, 30-V-1979, M. Silva \& C. Rosario 4704 (NY, INPA). MiNAS GERAIS: Alfenas, 1III-1969, J. Carauta 814 (R, RB); $10 \mathrm{~km}$ from Rio Doce at Govenador Valadares, 28-III-1976, G. Davidse, T. Ramamoothy \& D. Vital 11.457A (NY). Barbacena, 21-III1963, E. Pereira 7265 (NY). Caldas Novas, III-1865, A. Regnell s.n. (S): ídem. 10-V-1874. G. Mosén I790(S). Itaú, 30-VIII-1961, M. Emmerich 928 (R). Paraisopolis, 17-IV-1927, F. Hoehne 20218 (SP). PARÁ: Itaituba, estrada Santarém-Cuiaba BR 163, km 794. Serra do Cachimbo, l. Amaral \& al. 920 (INPA). PARANÁ: Apucarama, E of Maringá. 14-III-1966, J. Lindeman \& H. Haas 553 (F, LL, MBM, NY, WIS, U). Capão Grande, 23-II-1910, P. Dusén 9468 (G, S, US). Foz de Iguaçu, 30I-1969, R. Reitz \& R. Klein 12164 (MBM). Ivahy, 25-II1937, G. Tessman 6159 (G). Morungava, 13-II-1915, P. Dusén 16679 (M, S). Săo Sebastião, 25-IV-1932, G. Tessman 159 (RB). Terezinha, 26-I-1911, P. Dusén 11120 (G, NY, S, US). Umuarama, 22-VI-1967, G. Hatschbach \& H. Haas 16640 (MBM). RIO DE JANEIRO: Estrada dos Bandeirantes, near Itapeba, 17:III1963. G. Pabst 25310 (MO). Guanabara, Therezopolis, 30-I-1936, H. Mello Barretto 401 I (F). Itatiaia, 18-I1961, E. Santos 147 (MUS). Mont Corcovado, IV-1839, J. Guillemin 749 (F). Nova Friburgo, X-1842, Claussen s.n. (G). Vassouras-Aliança, 13-V-1980, G.V. Freire \& M.M. Silva 62 (MUS). Organ Mountains, III-1836, G. Gardner s.n. (E, G, NY). Petropolis, 1946, O. Goés 118 (NY, RB JB). Rio de Janeiro, 1839, J. Guillemin 743 (F, NY). Volta do Pião, estrada Nova Rio-Bahia km 50 , 29-I-1980, J. Semir s.n. (NY, UEC). RONDÔNIA: Ariquenes, 17-V-1982, L. Texeira \& al. s.n. (INPA).

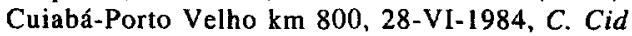
Ferreira \& al. 4868 (INPA). Jiparaná, 18-IV-1983, H. Paulinho Filho \& $M$. Silva s.n. (INPA). Presidente Medici, BR364. Rio Jiparaná, 4-V-1987, C. Cid Ferreria 9024 (NY). SANTA CATARINA: Anchieta, 29-II-1964, R. Klein 5034 (MBM, R). Capecó, 7-II-1951, P.R. Reitz \& L.B. Smith s.n. (MUS). Chapecó, 7-II-1951, R. Reitz 3695 (US). Itapiranga, 25-II-1957, L. Smith \& $R$. Klein 11811 (NY, US). Near Ponta Grossa, 4-III-1904, P. Dusén 4009 (S). Near Xanxerê, 27-II-1964, A. Castellanos 24631 (RB). São PAULO: Amparo, 26-III-1943, M. Kuhlman 385 (SP, US). Botucatu, 14-III-1967, J. \& N. Mattos 14443 (SP). Campinas, A. Heiner s.n. (S); ibidem, C. Morães 1069 (US). Campos de Jordão, 17-I1977. P. Occhioni 8026 (RFA). Galea, Estacão Ecológica dos Caiteus, 23-III-1997, F. Passos 34486 (UEC). Itapetininga, 4-IV-1947, J.L. Lima s.n. (RB). Jacarei, 24II-1994, J. Semir 304600 (UEC).Matão, 1996, A. Rozza 263 (ESA). Mogi das Cruces, 7-I-1994, J. Semir \& al. 30456 (UEC). Piraçicaba, 7-II-1984, E. Catharin 6 (ESA, SP, UEC). Porto Feliz, 1997, L. Bufo \& P. Sabadim 15 (HUEFS). Rodovia Avare-San Manoel, km 50, 15-III1967, J. Mattos s.n. (SP). Santa Rita do Passa Quatro,

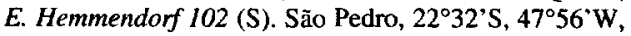
22-II-1996, S. Gandolfi \& al. s.n. (ESA); 5 km NW São Luis de Paratinga, Taubaté-Ubatuba, 8-I-1985, A. Gentry \& E. Zardini 49290 (MO). Serra da Cantareira, Pedra 
Blanca, 10-IV-1933, M. Koscinski 6354 (SP). Serra de Caracol, 10-II-1874, G. Mosén 1123 (S).

Paraguay. Alto Paraná: In regione fluminis, IV1909, K. Fiebrig 6184 (E, G, SI). Puerto Stroessner, 29 III-1983, L. Stuts 1602 (MBM). CaAguazú: Canendiyo, plants of the Aché indians $\left(24^{\circ} 12^{\prime} \mathrm{S}, 55^{\circ} 38^{\prime} \mathrm{W}\right), 22 / 27-\mathrm{V}$ $1980, K$. Hawkes 20 (MO). Cordillera Ybytyruzú (255' S, 56 $15^{\prime} \mathrm{W}$ ), 17-II-1989, E. Zardini \& C. Velasquez $10874(\mathrm{M})$. Guaira, Melgarejo-Antena. 5-VIII1989, E. Zardini 1/323 (MO). Without precise locality, III-1905, E. Hassler 8891 (G, MO, NY, P).

Peru. Cuzco: La Convención, between Hacienda Potrero and Quillabamba, 24-III-1989, P. Nuñez \& C. Cárdenas 10301 (WIS). $23 \mathrm{~km}$ E of Curahuasi, H. Iltis \& C. \& D. Ugent 750 (WIS). JuniN: Hacienda de Francia, Chanchamayo, Raimondi 8646 (photo F. NY). Outskirts of San Ramón, 1-VII-1987, A. Gentry 58674 (WIS). Satipo Reserva Forestal, 3-IV-1963, C. Vasquez I2 (MO). Valley of Rio Tulumayo, $10 \mathrm{~km}$ S of San Ramón, 5-VI-1983, A. Gentry, D. Smith \& N. Jaramillo 41518 (M). San MarTín: Janjuí, Alto Rio Huallaga, IV-1936, G. Klug 4304 (F).

4. Ceiba crispiflora (Kunth) Ravenna, Onira 3: 45 (1998)

Chorisia crispiflora Kunth in Humb., Bonpl. \& Kunth, Nov. Gen. Sp. 5, 297, tab. 485 fig. 2 (1822)

Ind. loc.: "In Brasilia legit Cel. Langsdorffius"

Type: Brazil. Mandioca, Langsdorff s.n. (lectotype, here designated, P! [herb. Humboldt \& Bonpland])

Tree $10 \mathrm{~m}$ or more with sometimes swollen, aculeate trunk. Leaflets denticulate. Pedicels 15-23 mm long. Petals c. $85 \times 6-$ $10 \mathrm{~mm}$, very narrowly oblong, margin markedly undulate-crespate, sericeous externally, glabrous internally, dark pinkish-magenta with few striations distally, yellowish at the base. Staminal column c. $15 \mathrm{~mm}$ to the appendages, cinereous sericeous; appendage lobes hairy, dark red, staminal tube above the appendages glabrous. Stigma white or pink. Fruit an ellipsoidal to pyriform capsule c. $15 \times$ $10 \mathrm{~cm}$.

Flowering February-March. Mata Atlântica and coastal restinga. Brazil (near Rio de Janeiro). Cited further [cf. SANTOS (1967)] south but probably for cultivated material.

Illustrations. SANTOS (1967: 9 fig. 2), SAN$\operatorname{Tos}(1969$, fig. 4):
Very similar to $C$. speciosa in most features, but the narrow, markedly undulate margined petals, and pubescent lower staminal tube, resemble $C$. ventricosa (see below). Apparently restricted to atlantic forest and restinga around Rio de Janeiro and so partially sympatric with $C$. speciosa. DE CANDOLLE (1824: 480) treated $C$. ventricosa (see below) as a synonym of $C$. crispiflora, which is not surprising since both species have narrow, undulate-crespate petals. Indeed, the flowers of C. crispiflora resemble what might be expected in a hybrid between $C$. speciosa $\times C$. ventricosa, but we have absolutely no evidence of such hybrid status.

\section{Examined specimens}

Brazil. Minas Gerais: Carangola, $20^{\circ} 40^{\prime} S$, 42.01W. 14-II-1990, LS. Leoni, E. Santos \& V. Martins s.n. (BRAD). RIO DE JANEIRO: Estrada de Jacarepaguá, 24-II-1959, E. Pereira 4491 (RFA). Estrada do Páu Ferro, Jacarepaguá, 11-III-1959, P. Duarte 4627 (RFA). Itainhangá, II-1962, O. Alves de Silva \& I. Vattimo s.n. (JB). Lagôa Rodrigo de Freitas, 18-III-1936, O.J. de Souza 244 (RB). Near Petropolis, 27-III-1964, L.A. Trinta 549 \& E. Fromm 1625 (MUS). Nova Friburgo, Macáe de Cima, 26-II-1994, C.M. Vieira \& L.C. Gurken 554 (RB). Rio das Flores, entre Abarracamento e Andrade Pinto, 4-III-1980. J.P. Carauta \& al. 3449 (GUA, NY). Serra dos Orgãos km 60, VI-1975, $P$, Occhioni 7456 (RFA).

5. Ceiba ventricosa (Nees \& Mart.) Ravenna, Onira 3 (15): 47 (1998)

Chorisia ventricosa Nees \& Mart., Nova Acta Phys.-Med. Acad. Caes. Leop.-Carol. Nat. Cur. 11: 102, tab. 9 (1823)

Bombax ventricosa Arruda in H. Kost., Trav. Brazil: 489 (1816), nom. nud.

Ind. loc.: "In sylvis, Cascam late cingentibus, inter Rio das Contas et Tiquirica, fluvios prope a loco, quem Cabeça do Boi incolae voeant. Martio mense flores deiecti terram ad arboris radices tegebant. Princeps Maxim Neov."

Type: Brazil. Bahia, inter Rio das Contas et Tiquirica, Maximillian von Wied s.n. (no original material located at BR) [Bahia, Rio Jequitinonha, Itapebi, 17-IV-1971. T.S. dos Santos 1579 (neotype, here designated, NY!; isotypes, CEPEC! UEC!)] 
Chorisia incana Robyns, Ann. Missouri Bot. Gard. 54: 184 (1967); Ceiba incana (Robyns) Ravenna, Onira 3 (15): 47 (1998) Ind. loc.: "Bahia, rodavia Itabuna-Ilheus, beira da estrada"

Type: Brazil. Bahia, Rodavia Itabuna-Ilhéus, IV-1965, Belém \& Magalhães s.n. (holotype, BR; isotype, MO!)

Trees $10 \mathrm{~m}$ or more with swollen, aculeate trunk. Leaflets somewhat chartaceous, glabrous, usually entire, sometimes obscurely denticulate. Pedicels c. 20-30 mm long. Petals c. $60 \times 8-10 \mathrm{~mm}$, narrowly oblong with a markedly undulate-crespate margin, externally sericeous, internally glabrous, white to cream, with sparse dark reddish flecks distally, these merging more uniformly towards the base, becoming chocolate-brown in old flowers and dried specimens. Staminal column densely reddish-sericeous up to and including the 5 staminal appendages which are prominently bifid, then a glabrous, whitish staminal tube to the 5 sinuous anthers. Stigma somewhat 5-lobed, white. Fruit not seen.

Flowering February-April. Dry semi-deciduous woodland. Brazil (Bahia, Espírito Santo, E Minas Gerais, Pernambuco, Paraiba) (fig. 1).

\section{Illustrations. ROBYNS (1967: 185 fig. 1).}

Harley (in litt.) notes that Prince Maximillian von Wied probably travelled upstream from near Jequié, on the Rio de Contas and headed north, spending the night at the locality Cabeça de Boi (which no longer exists) and then another night near where he probably collected Chorisa ventricosa, before reaching Santa Inês on the Rio Jiquirica (= Tiquirica). Although the natural vegetation is much devasted today, this is an area of of deciduous dry forest. Since no specimen of Chorisia ventricosa has been located in the von Wied herbarium at BR, we choose as an epitype for this species dos Santos 1579.

RoBYNS (1967) described his Chorisa incana apparently unaware of the previously described Chorisia ventricosa, perhaps because this latter species was treated as a synonym of $C$. crispiflora by SCHUMANN (1886) in Martius' Flora Brasiliensis. The similarity between these two species is particularly marked in herbarium specimens which have lost flower colour. Given differences in artistic style, the illustration of $C$. incana (ROBYNS, 1967 ) is remarkably similar to that of $C$. ventricosa in NeEs \& MARTIUS (1823, tab. 9).

Presumably with its pallid flowers, $C$. ventricosa is another species with crepuscular anthesis and nocturnal pollinators.

\section{Examined specimens}

Brazil. Bahia: Feira de Sant Ana, Fazenda Boa Vista, L.R. Noblick 3112 (HFSA). Ibicarai, 24-III-1989, L. Queiroz \& I. Crepaldi 2189 (HUEFS). ItajuípeUbaituba, 24-IV-1965, Belém \& Magalhães 868 (CEPLAC, UB, UEC). Pimenta-Mascote, 24-II-1972, T.S. dos Santos 2283 (CEPEC. NY). Rio Jequitinonha, Itapebi, 17-IV-1971, T.S. dos Santos 1579 CEPEC, NY, UEC). Rui Barbosa, margen de BR241 depois de Itaberaba, 10-VIII-1981, G.P. Pinto 75/81 (HUEFS). EsPiRTro SANTO: Vargem Alta, 26-II-1991, V. de Souza 27 (RB). MINAS GERAIS: Entre Itambacuri and Governador Valadares, 26-IV-1964, Z.A. Trinta \& E. Fromm 1917 (NY, R). Pernambuco: Entre Bom Nome e Jati, 14-V-1971, E.P. Heringer \& D. Andrade Lima 755 (RB). PARAIBA: Areia, Escola de Agronomia do Nordeste, cult?, J. Coêlho de Moräes 900 (US).

6. Ceiba chodatii (Hassl.) Ravenna, Onira 3(15): 44 (1998)

Chorisia chodatii Hassl., Bull. Herb. Boissier ser. 2, 7: 174 (1907)

Ind. loc.: "In campis Santa Elisa (Chaco septentrionalis), April"

Type: Paraguay. Chaco septentrionalis, in campis Santa Elisa, Rojas s.n., herb. Hassler 2849 (lectotype, here designated, G!)

Tree c. $12 \mathrm{~m}$ or more with swollen, sometimes aculeate trunk. Leaflets somewhat coriaceous, denticulate. Pedicels 8-20 mm long. Petals $83-130 \times 20-27 \mathrm{~mm}$, usually held erect and so flower more or less funnel-form, spathulate, softly hairy externally, glabrous internally, ivory to pale yellow, occasionally with some crimson flecks. Stamens with a glabrous basal tube, $10-15 \mathrm{~mm}$, staminal appendages pale white-yellow, glabrous, upper staminal tube white with a collar of 5, 2-thecate, sinuous, pale yellowish anthers, occasionally splitting distally to give 5 short filaments and separate anthers. Stigma pinkish- 
red. Fruit an elongate-pyriform capsule 15-18 $\times 8-10 \mathrm{~cm}$.

Flowering February to May. Dry, seasonal woodland. Paraguay, Bolivia and piedmont mountains of W Argentina (fig. 1).

Illustrations: DIGILIO \& LEGNAME (1906: 76, sub C. insignis); BERNARDINI (1984: 35 fig. 10, sub C. insignis).

Cultivated trees in Campinas (Brazil) and Rosario (Argentina), the latter possibly of hybrid origin, open their flowers in the late afternoon, and it is likely that $C$. chodatii, with its erect pallid colored petals is another species with crepuscular-nocturnal pollinators. However, given that the species has a distribution largely outwith that of flower-visiting bats, and the nectar supply is sparse, these are likely to sphingid moths.

As noted above, Hicken in 1900 identified cultivated trees of $C$. chodatii from La Recoleta, Buenos Aires as $C$. insignis Kunth, and this initiated a long period of misidentification of exsiccata of $C$. chodatii from Argentina, Bolivia, Brazil and Paraguay as Chorisia insignis Kunth.

\section{Examined specimens}

Argentina. Buenos Aires: Paseo de La Recoleta, cult., 18-III-1900, C.M. Hicken (SI). CATAMARCA: La Quebrada, 15-II-1945, A. Krapovickas 1792 (CAS). Piedra Blanca, 22-XI-1909, P. L. Spegazzini 33933 (BAB). Santa Rosa, Alijilan, 21-I-1942, S. Pierotti 11549 (NY, U). CHACO: Chaco, P. Jorgenson 1967 (MO). Fontana, V-1938, T. Meyer 710 (F, LIL). JuJuY: El Potrerillo, 6-II-1939, E.K. Balls 5923 (E). Esperanza, 8IX-1901, $R$. Fries 50a (S). Fraile Pintado-Guayacan, 19III-1973, A. Cabrera \& al. 23435 (F). San Pedro, Las Lajitas, 27-II-1971, A. Cabrera \& al. 21656 (F). San Pedro la Mendieta, 15-II-1937, J. West 8358 (MO). Santa Bárbara, camino a Palma Sola, A. Cabrera, A. Chicchi \& P. Hernández 13865 (BAB). LA Rioja: Chilecito, I-1901, A. Giaconelli I00 (BAB); ibidem. 28-II-1941, A. Burkart 12.477 (SI). SALTA: Embarcación, 23-II-1909, S. Venturi 315 (BAF). Hickman, 12-V-1945. S. Pierotti 1387 (NY, S). Santa Cornelia-Santa Bárbara, Schuel 90 (BAB). Tartagal, 24-II-1924, Schreiter 3598 (NY). $10 \mathrm{~km}$ W of Hickman, 2-IV-1977, A. Krapovickas \& A. Schinini 30824 (F). Santiago del Estero: C. Pellegrini, Cerro Remate, 28-II-1928, S. Venturi 6045 (F, MO, SI). TUCUMÁN: Burrayacú, 10-III-1944, A. Varela s.n. (NY). Cañada Alegre near Tucumán, 23-III-1909, T. Stuckert 19971 (G). Capital, Barranco Colorado, 24-IV-1925, S. Venturi $149 c$ (BAB). Famarilla. III-1946, E. Wall \&
B. Sparre 162 (S).Rio Ureña, ruta 34, 23-III-1977, A. Krapovickas \& A. Schinini 30501 (F; SI). Tucumán, X-1957, Olrog s.n. (S). Vipos, 3-III-1924, S. Venturi 3235 (US).

BolIVIA. TARIAA: Tarija, VII/VIII-1846, N.H. Weddell s.n. (P).

Paraguay, BoQuerón: C. del Fortín Teniente Montanía, 18-X-1981, J.A. Fernandez Casas \& J. Molero 4281 (NY). Colonia Fernheim, Filadelfia, VI-1981, $P$. Arenas 1883 (SI). Filadelfia, $22^{\circ} 20^{\prime} 60^{\circ} 05^{\prime} \mathrm{W}, 13-\mathrm{III}-$ 1979, A. Schinini \& E. Bordas 16563 (NY, SI). CHACO: Concepción. VI-1944, C. Sandeman 4843 (K). PresiDENTE HAYES: Km 326 from Asunción, 3-III-1980, Bernardi 20131 (G). Pilcomayo river, IV-V-1888, Morong $1075(\mathrm{NY})$.

7. Ceiba pubiflora (A. St.-Hil.) K. Schum. in Mart. (ed.), Fl. Bras. 12(3): 213 (1886)

Eriodendron pubiflorum A. St.-Hil., Fl. Bras. Merid. 1: 266 (1828); Chorisia pubiflora (A. St.-Hil.) G. Dawson, Revista Argent. Agron. 2 (1): 3 (1944)

Ind. loc.: "Prope praesidiolum vulgo Quartel de Texeira (Minas Novas)"

Type: Brazil. Minas Gerais, prope praesidiolum vulgo Quartel de Texeira, Minas Novas, Saint Hilaire s.n. (lectotype, here designated, P!)

Ceiba fiebrigii Hochr., Annuaire Conserv. Jard. Bot. Genève 10: 23 (1907)

Ind. loc.: "Paraguay, Cordillera de Altos"

Type: Paraguay. Cordillera de Altos, VIII1902, K. Fiebrig 3 (lectotype, here designated E!; isolectotypes, F!, G!, NY photo!, MO! SI!)

Ceiba jaibana Ravenna, Onira 3(15): 48 (1998)

Ind. loc.: "Arboreal caatinga near Jaiba, middle São Francisco river region, northern Minas Gerais"

Type: Brazil. Minas Gerais, Jaíba, 16 May 1985, Pedralli \& al. s.n. (holotype, HXBH!)

Trees with sometimes ventricose, aculeate trunk. Leaflets somewhat chartaceous, usually serrate. Pedicels $5-10 \mathrm{~mm}$ long. Petals 47 $85 \times 20-25 \mathrm{~mm}$, initially somewhat erect, subsequentially spreading, obovate-oblong, margin somewhat undulate, sericeous externally, glabrous internally, uniformly pale pink with sparse dark flecks, or deep pinklilac with conspicuous carmine striations 
which may coalesce midlength. Staminal column glabrous, 10-15 mm long; staminal appendages pink-yellowish, glabrous, with five bifid lobes; above the appendages the column divides either immediately, or at c. 5$10 \mathrm{~mm}$, into 5 usually strongly resupinate, white filaments which have large, sinuous anthers. Stigma white. Fruit a somewhat rotund to ellipsoidal capsule, $10-15 \times 8-10 \mathrm{~cm}$.

Flowering February-May. Semi-deciduous woodlands, particularly on calcareous soils. Argentina (Missiones), Paraguay, CentreWest Brazil from Corumbá to NE Minas Gerais, extending to Bahia and Espírito Santo (fig. 1).

Illustrations. SANTOS (1964: 169 tab. 4), BERNARDINI (1984: 33 fig. 9), LORENZI (1998: 46): the photo on page 42 , labelled $C$. boliviana, depicts a dark pink form of $C$. pubiflo$r a$ (fig. 2).

Flowers rather variable in size, and also include forms ranging from pale pink petal with very few striations, to others flushed dark pink-lilac and with distinct dark, winecoloured striations which tend to coalesce. C. pubiflora has diurnal anthesis. Flowers on trees in Bahia, and also in cultivation in São Paulo, were observed to be frequently visited, and so probably pollinated, by humming birds.

RAVENNA (1998) described his $C$. jabaibana with entire margined leaflets, and pink, $7-8 \mathrm{~cm}$ flowers with petals externally tomentose. The important details of the androecium were described as: "Columna staminum circ. $30 \mathrm{~mm}$ longa, laevis, ad basin $3 \mathrm{~mm}$ lata, apicem versus sensim angustiora. Filamenta oblique patentia, 13-15 mm longa. Antherae oblongae, modice flexuosae, $9-10 \mathrm{~mm}$ longae, $1.5-1.8 \mathrm{~mm}$ latae".

We have studied the type material of $C$. jaibana, and also had the opportunity to study some 11 carefully annotated collections of Ceiba trees recently made at our suggestion in the Montes Claros-Jaíba-Janaúba area of Minas Gerais by E.R. Salviani and J. Dutilh. The holotype consists of a twig with a single, broken flower, with two remaining stamens. The petals are similar to those of $C$. pubiflora, but the basal staminal tube does not have a collar of staminal appendages as occurs in that species, but rather a swelling, thus resembling C. erianthos. The paratype has leaves with an entire margin and an open fruit with kapok. It does not convincingly appear to correspond to the same plant as the holotypus, but could well be a specimen of $C$. pubiflora.

It is curious, and perhaps significant, that RAVENNA (1998), in making his comparisons between $C$. jaibana and diverse Ceiba species, did not comment on the common occurrence of $C$. pubiflora in this caatinga-like area of N Minas Gerais. In view of the (a) general similarity of the fragmentary type material of $C$. jaibana to $C$. pubiflora, with the exception of enigmatic lack of staminal appendages in the solitary flower available; (b) also taking in to account that flower size in C. pubiflora can be variable-it is notable that flowers of the collection of this species by $P i$ rani \& al. 4276 from Porteirinha, a locality only some $30 \mathrm{~km}$ from the Jaiba area, are particularly small in size, but otherwise in accord with $C$. pubiflora, and (c) the general prevalence of $C$. pubiflora in the Jaiba area, we conclude that $C$. jaibana is in fact a synonym of C. pubiflora.

\section{Examined specimens}

ARgentina. Misiones: Bonpland, II-1910, P. J $\phi r-$ gensen 729 (BAB, MO, NY).

Brazil. BAHIA: Abaira, estrada para Catolés, c. $5 \mathrm{~km}$ do entronamento com a estrada Boninal-Abaira, 18-IV1998, L. de Queiroz s.n. (HUEFS); ibidem, estrada Catolés-Ouro Verde, c. 2 km Ouro Verde, 15-V-1998, E. Miranda Silva 501 \& al. (HUEFS). Aurora-Umburanas, 25-IV-1999, R. Forzza, A. Amorim \& S. Sant'ana 1365 (SPF). Campo Alegre de Lourdes, Morro de Carlota, 21-V-2000, L de Queroz \& al. 6246 (HUEFS). Estação de Picus, 16-VII-1959, E. Santos 87 (MUS). Ibotirama-Barreiras, $\mathrm{km} 46,12^{\circ} 12^{\prime} \mathrm{S}, 43^{\circ} 34^{\prime} \mathrm{W}, L$. Coradin \& al. 560 (K. MBM). Irecê, 18-VI-1994, $L$ de Queiroz \& N. Nascimento 3994 (HUEFS). Rio de Contas, Fazenda Veredas, $7 \mathrm{~km}$ from Jussiapé, 14-VI-2000, R. Harley \& A.M. Giulietti s.n. (HUEFS). Sta. Maria de Vitoria, 17-II$2000, L$ de Queiroz \& al. 6121 (HUEFS). Tucano, 7 $12 \mathrm{~km} \mathrm{~N}$ of Cipó, 23-IX-1996, L. de Queiroz \& N. Nascimento 4564 (HUEFS). $10 \mathrm{~km} \mathrm{~W}$ of Cocos, 17-V-2001, F. Franca 3630, E. Melo \& B. Marques da Silva (HUEFS). $10 \mathrm{~km}$ João Dourado on road to Irecê, 28-V2000, R. Harley \& A.M. Giulietti s.n. (HUEFS). DistRITo FEDERAL: Area da Barragem de São Bartolmeu, 14-V- 


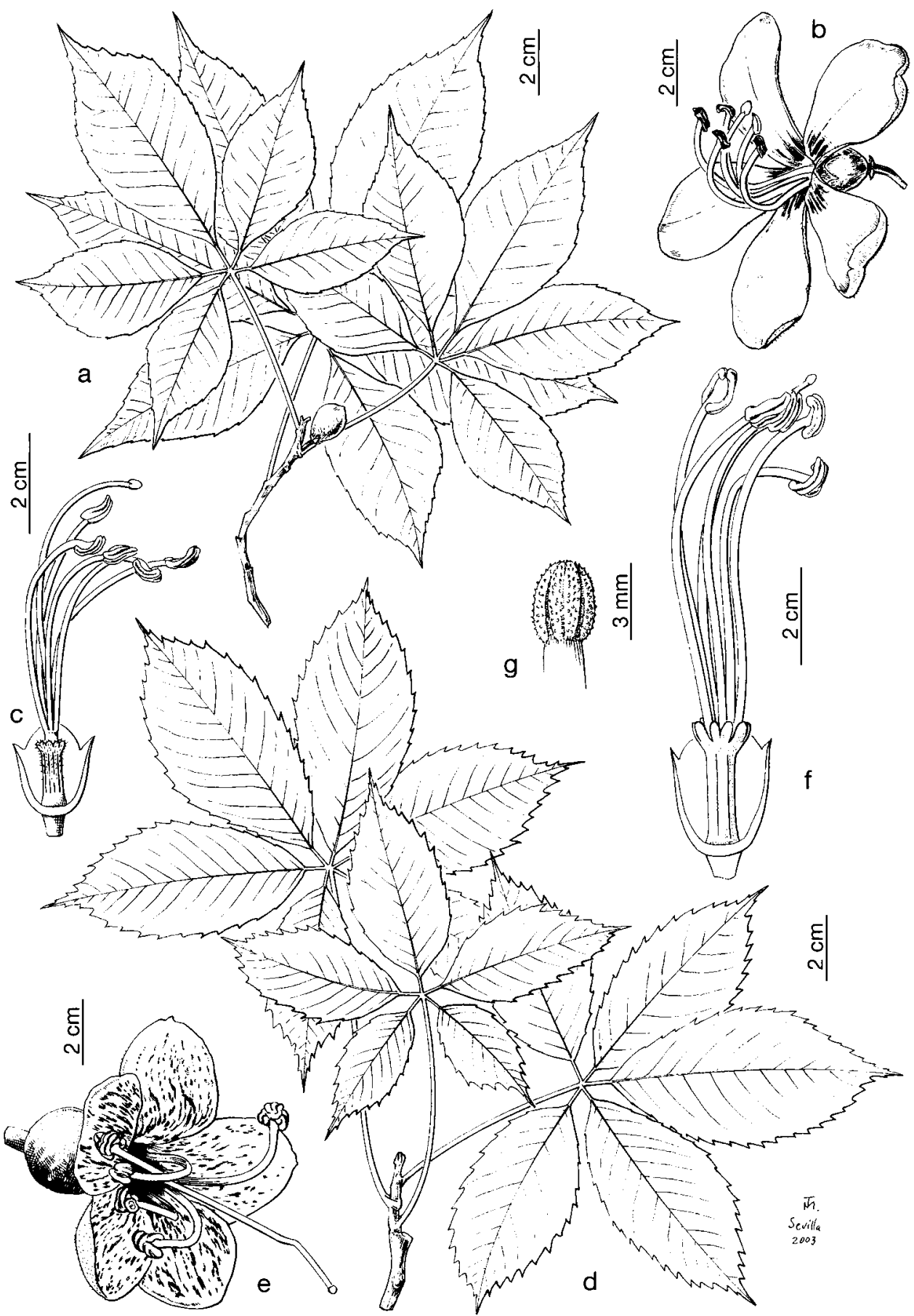

Fig. 2.-Ceiba pubiflora (Pott, Cunha \& Tavares 2799, E): a) branch with leaves and floral bud; b) flower at anthesis; c) androecium. Ceiba boliviana (Nee 34329, E): d) branch with leaves; e) flower at anthesis; f) androecium; g) stigma. 
1980, E.P. Heringer \& al. 4760 (MO). Bacia do Rio São Bartolomeu, 28-V-1980, E. Heringer \& al. 4950 (MBM). Côrrego Landim, $20 \mathrm{~km}$ NE Brasília, 7-V-1966, H.S. Irwin \& J.W. Grear, R. Souza \& R. Reis dos Santos 15694 (F, MO, NY, US). Limestone rocks near Fercal, 11-X1963, B. Maguire \& al. 57037 (MO, NY). Near Rio Salinas ( $15^{\circ} 31^{\prime} S, 47^{\circ} 57^{\prime} \mathrm{W}$ ), 24-IV-1981, J. Kirkbride 4354 (SP). ESPíRTro SANTO: Estrada do Patrimonio, perto de Colatina, 16-V-1934. E.G. Kuhlman 342 (F, NY, RB). Reserva CVRD, Linhares, 19-V-1980, D.A. Folli 227 (MO, MUS). Golás: Chapada dos Veadeiros, road to Nova Roma, S. Bridgewater, J. Fonseca \& J. Ferreira Paixão S203 (K). Corumbá de Goiás, 20-VI-1973, E.P. Heringer 12150 (NY, UEC). Cristalina, 7-VII-1963, C.T. Rizzini \& A. Mattos 32 (RFA); ibidem, 20-IV-1976, Mattos, E.P. Heringer \& J. Murça Pires 321 (RB. UNB). Ipamiri, 20-IX-1996, T.B. Cavalcanti \& al. 20.63 (CEN). Paraiso-Cavalcante, L.E. de Mello 4302 (MUS). Monte Alegre (13 $\left.09^{\prime} \mathrm{S}, 46^{\circ} 39^{\circ} \mathrm{W}\right), 14-\mathrm{VI}-2000$, F.C.A. Oliveira, \& al. s.n. (MUS). Posse ( $\left.14^{\circ} 10^{\prime} \mathrm{S}, 46^{\circ} 15^{\prime} \mathrm{W}\right)$, 28-IV-1996, B.A.S. Pereira \& D. Alvaringa 3006 (MUS, UEC). Serra do Caipó, $50 \mathrm{~km}$ S of Caiapônia, 28-VI1966, W.S. Inwin, R. Souza, J.W. Grear \& R. Reis dos Santos 17951 (F, MO, NY. RB. US). Uruaçu, Serra da Mesa, 5-V-1998, B.M.T. Walther \& al. 41.12 (CEN). Mato Grosso: Jauru-Araputanga, 6-V-1995, G. Hatschbach \& al. 52447 (ESA). MATO GROsso SUL: Corumbá, 20-VI-1979, G.T. Prance 26254 (CEN, NY); ibidem, Estrada para Forte Coimbra, proximo a Fazenda Coqueiro, 2-VI-1989, V.J. Pott \& al. 834 (CPAP); ibidem, Estrada de Tamarindeiro, 23-V-1987, A. Pott \& al. 2799 (CPAP); ibidem, Moro do Jacadigo, 25-VI-1993, G.A. Damasceno Jr. s.n. (UEC); ibidem, Moro do Urucum, 3-VI-1993, G.A. Damasceno Jr. 29980 (UEC). MINAS GERAIS: Aracuás-Virgem da Lapa, 2-VI-1967, A.P. Duarte 10451 (RB). Arinos-Unái, 15 $30^{\prime}-16^{\circ} 10^{\prime}$ 's, $46^{\circ} 10^{\circ}-47^{\circ} 30^{\circ} \mathrm{W}, 2-\mathrm{V}-1996$, B.A.S. Pereira \& D. Alvarenga 3057 (RB, MUS). Barra, 13-VII-1979, G. Hatsbach 42330 (MBM). Belo Horizonte-Conceição do Mato Dentro, 4-V-1986, K. Kubitzki \& J. Rower CFSC 9808 (SPF). Espinosa, BR-122, 19-IV-1983, G. Hatschbach 46574 (MBM). Estrada Serraria-Jaíba, 10 km, 19-V2002, E.R. Salviani 2259 \& J. Dutilh (UEC). Granjas Reunidas, Ramal Montes Claros, 2-V-1963, A.P. Duarte 7807 (F, RB). Itacarambí-Januária, Fazenda Olhos d'Agua, 20-V-2002, E.R. Salviani 2264 \& J. Dutilh (UEC). Jaíba, estrada para Varzelândia, 19-V-2002, E.R. Salviani 2256 \& J. Dutilh (UEC). Januaria, 24-VI1932, Campos Porto 2519 (RB). Januária-Montes Claros, km 354, E.R. Salviani 2267 \& J. Dutilh (UEC). Janaúba, 18-V-2002, E.R. Salviani 2251 \& J. Dutilh (UEC). Janaúba-Jaíba, $10 \mathrm{~km}$ antes de Jaíba, 18-V-2002, E.R. Salviani 2253 \& J. Dutilh (UEC). Montes Claros, $16^{\circ} 09^{\prime} \mathrm{S}, 43^{\circ} 52^{\prime} \mathrm{W}$, E. Almeida 58 (RB). Porteirinha, 12V-1998, J.R. Pirani \& al. 4276 (SPF). Rodovia (BR 122) para Mato Verde, $10 \mathrm{~km}$ N. PARANÁ: Londrina (cult.?), 5V-1994, F. Chagas e Silva \& L.H. Soares-Silva 1685 (ESA). SÃo PAULO: Estação Biologica de Paulo de Faria, $19^{\circ} 55^{\prime} \mathrm{S}, 49^{\circ} 31^{\prime} \mathrm{W}, 26-\mathrm{IV}-1994$, V. Stranghetti 303 (UEC); ibidem, $19^{\circ} 58^{\prime} \mathrm{S}, 49^{\circ} 31^{\prime} \mathrm{W}, 20$-IV-2001, J. Tomasetto 157 \& A.A. Resende (SJRP, UEC). Estrada margens do Rio Paraná, 4-VI-1972, P. Occhioni 1918
(JB). Lins, 16-IV-1995, J. Semir 33615 (UEC). Magda, Fazenda CFM, 17-V-1995, Bernacci \& al. 1887 (SPS). Pindorama, 18-V-1939, O. Mendes 264 (RB); ibidem, Fazenda Elidio Ribeiro, 18-V-1939, O.T. Mendes 264 (SP). São José do Rio Preto-Penápolis (BR 153), 4-V2002, F. Tomasetto 287 (SJRP, UEC).

Paraguay. Cerro Acahay, Carapegua-Ybcui, D.R. Brunner 1141 (NY). CORDILLERA: Asunción, 15-V-1889, T. Morong 725 (NY). Cerro Palacios, 8-VI-1988, E. Zardini 4633 (MO). $5 \mathrm{~km}$ SE of Emboscada, 9-VI-1990, E. Zardini \& E. Velasquez 21248 (MO). Pr. Sapucay, IX-1913, E. Hassler 12954 (E, MO). San Bernardino, VI-1900, E. Hassler $7150 d$ (G). Yparacaray, V-1913, E. Hassler 11724 (BAF, E, G, MO, NY). GuaIRA: Villarica, III-1913, P. Jorgensen 3933 (MO, NY, US). SAN PEDRO: Colonia Primavera, 23-VI-1956, A. Woolston 691 (P, SI).

8. Ceiba boliviana Britten \& Baker f., J. Bot. 34: 175 (1896)

Ind. loc.: "Hab. Bolivia"

Type: Bolivia. Vil. Cochabamba, 1891, A.M.

Bang 1154 (lectotype, here designated, BM!; isolectotypes, E!, G!, MO!, NY!, S!, US!, W!)

C. mandoni Britten \& Baker f., J. Bot. 34: 175 (1896)

Ind. loc.: "Hab. Vicinnis Sorata ad radicam collis Catarguata in scopulis. Prov. Larecaja, Bolivia, G. Mandon 825; alt 2550 m." Type: Bolivia. Larecaja, vic. Sorata, Catarguata, 3-VI-1860, Mandon 825 (lectotype, here designated, NY!; isolectotypes, G!, P!, F photo!, MO!)

Xylon tunariensis Kuntze, Rev. Gen. Pl. 3(2): 23 (1898); Ceiba tunariensis (Kuntze) K. Schum., Just's Bot. Jahresber. 26: 343 (1900)

Ind. loc.: "Bolivia: Tunarigebirge $1300 \mathrm{~m}$ " Type: Bolivia. Tunari, O. Kuntze s.n. (lectotype, here designated, NY digital image!) Chorisia grandiflora Rusby, nom. nud.

Trees c. $10 \mathrm{~m}$ with usually with swollen, aculeate trunk. Leaves 5-7 foliolate, petioles 35-135 mm; leaflets $95-110 \times 35-50 \mathrm{~mm}$, oblanceolate, denticulate, glabrous, with petiolules 5-10 mm long. Flowers axillary, borne singly or in fascicles. Pedicels c. $12 \mathrm{~mm}$ long, stout. Calyx $32-40 \times 20-23 \mathrm{~mm}$, broadly campanulate, lobed. Petals $75-110 \times 25-35 \mathrm{~mm}$, held erect and so flower rather campanulate, broadly spathulate, externally densely sericeous-villous, internally glabrous, white- 
pinkish, with many conspicuous dark red striations. Staminal column $20-40 \mathrm{~mm}$ up to appendages which have 5 glabrous bifid lobes, the column then continuing for some 3$15 \mathrm{~mm}$ before dividing to 5 red filaments which bear versatile, anfractuose anthers. Ovary pyriform, with slender style bearing the red globose stigma well beyond the anthers. Fruit an ellipsoidal to pyriform capsule, $15-18 \times 10-15 \mathrm{~cm}$.

Flowering (January)March-April. Woodlands in dry valleys. Bolivia and S Peru (fig. 3).

\section{Illustrations. Fig. 2.}

BRITTEN \& BAKER (1896) distinguished C. mandoni from C. boliviana with the former having more leaflets (6-7 vs. $3-4)$ which are slightly more long petiolulate and with more marked serrations, and the staminal appendages much nearer the apex of the staminal tube rather than near the centre as in C. boliviana. However, in material seen by us these characters are variable, sometimes between flowers of the same specimen, and so are unreliable to delimit species. The description of

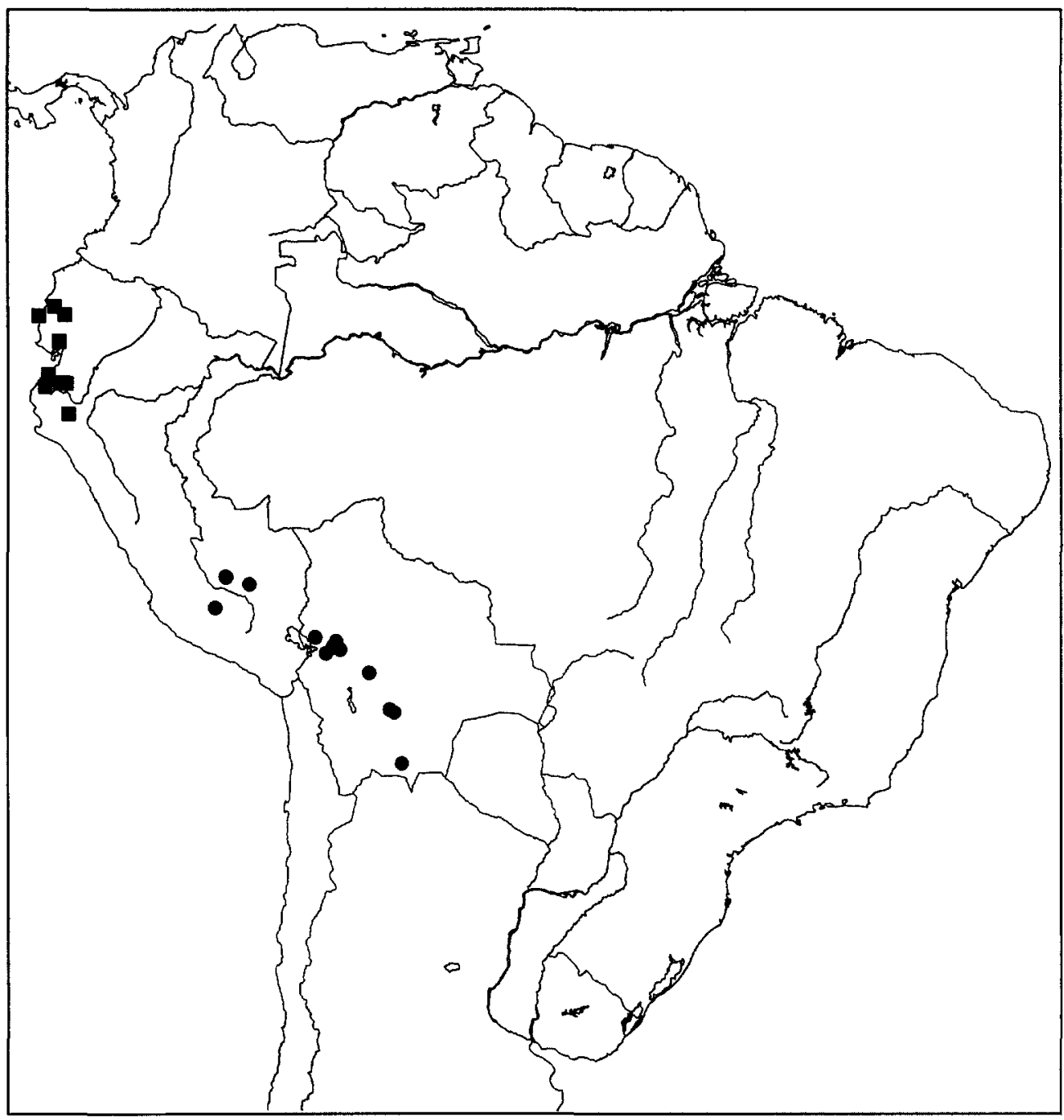

Fig. 3.-Distribution map of Ceiba boliviana and $C$. trischistandra. 
KUNTZE's (1898) Xylon tunariensis, particularly the anfractuose anthers and Bolivian provenance, accord with $C$. boliviana.

$C$. boliviana resembles species of the $C$. insignis aggregate, but the usually large, robust, campanulate flowers, with densely whitehairy, whitish-pinkish coloured petals that have prominent anastomosing dark reddish striations, and the red stamen filaments with anfractuose anthers are very distinctive. MACBRIDE (1956) in his Flora of Peru, identified specimens of $C$. boliviana: Weberbauer 5874 and Vargas 7195, as Ceiba pubiflora.

Field observations by Nee \& Solomon 36519 note that "at $12.35 \mathrm{pm}$ flowers open but old and falling, with an unpleasant smell, probably bat-pollinated".

\section{Examined specimens}

Bolivia. Chuquisaca: Tarabuco-Zudanez, J.R. Wood 8007 (K). Vila-Vila, Sucre, IV-1933, Cardenas 543 (NY). CochaвAmba: Chulumani, 28-VI-1961, L.G. Holliday 20 (K). Comarapa, Sorata, Fries 1924 (S). Km 186 on Cochabamba-Sta. Cruz highway, 20-IV-1963, D. \& V. Ugent 5106 (WIS). LA PAZ: Coroico, $10 \mathrm{~km}$ hacia Caranavi, S. Beck 1771 (MO). $10 \mathrm{~km} \mathrm{SW}$ of Yolosa, on road to Chuspipata, J. Solomon \& M. Wehling 122244 (MO, WIS). La Paz-Chuspipata, 21-I-1984, A. Gentry \& J. Solomon 44391 (MO). La Paz-Coroico, 31-III-1977, J.D. Boeke 1414 (NY). Puente Villa, 22-IX-1979, S. Beck 2257 (MO). Santa Cruz: Andrés Ibáñez, Santa Cruz, $170^{\circ} 47^{\circ}-63^{\circ} 11^{\prime} \mathrm{W}, 30-\mathrm{I}-1989, M$. Nee 36519 (NY, SI). Cochabamba-Sta. Cruz, km 367, III-1961, M. Cardenas 5920 (WIS). Gorge of Rio Achira on road Sta. CruzSamaipata, 8-III-1988, $M$. Nee \& J. Solomon 36519 (NY, SI). TARIJA: Chiquiata, 8-III-1904, K. Fiebrig 2707 (S, U). $60 \mathrm{~km}$ S of Tarija, 17-III-1965, Badcock 630 (K).

PERU. APURIMAC: Apurimac, 12-VI-1911, A. Weberbauer 5874 (F). Cuzco: Convención, Sta. Rosa, C. Vargas 7195 (F). Hacienda Sta. Rosa, V-1937, J. Soukup 513 (F). La Convención, Quillabamba, T.D. Pennington, J. León \& M. Cavero 15060 (K); ibidem, $12^{\circ} 53^{\prime} \mathrm{S}$, $72^{\circ} 44^{\prime}$ W, P. Nuñez \& J. Arque y Flavio 8262 (WIS).

9. Ceiba glaziovii (Kuntze) K. Schum., Just's Bot. Jahresber. 26: 343 (1900)

Xylon glaziovii Kuntze, Rev. Gen. Pl. 3(2): 23 (1898); Chorisia glaziovii (Kuntze) E. Santos, Sellowia 16: 164 (1964)

Ind. loc.: "Brasilia no. 17467 ; 18145a Glaziou"

Type: Brazil. Rio de Janeiro, São Cristovão, Glaziou 18145a (lectotype, here designated P!; G! isolectotype)
Trees usually $10-15 \mathrm{~m}$, with swollen, aculeate trunk. Leaves 4-7 foliolate, petioles 60 $90 \mathrm{~mm}$ long; leaflets 50-130 $\times 30-60 \mathrm{~mm}$, chartaceous, elliptic-oblanceolate, denticulate, especially distally, acuminate, glabrous, with petiolules 2-4 mm long. Flowers in fascicles of three or solitary. Pedicels 6-10 mm long. Calyx 20-28 mm, campanulate, glabrous, with 3-5 lobes. Petals c. $65 \times 25 \mathrm{~mm}$, spathulate, spreading, white, externally villous, internally glabrous basally, hairy distally, sometimes with magenta striations towards the base. Staminal tube $10-50 \mathrm{~mm}, 5$ entire appendages, all covered with dense hairs; tube continuing above the appendages for $3-20 \mathrm{~mm}$ and then dividing into 5 spreading, white filaments which terminate in yellow, sinuous anthers. Ovary subglobose, with the slender style terminating in a white globose stigma a little above the anthers. Fruit elongate to ellipsoidal capsule, c. 8$12 \times 5-9 \mathrm{~cm}$.

Flowering July-September. Dry woodlands (Caatinga). NE Brazil (Bahia, Pernambuco, Paraíba, Ceará) (fig. 4).

Illustrations. SANTOS (1964: 170 fig. 5), LORENZI (1998: 45).

The specimen Glaziou 18145a, cited by Kuntze for his Xylon glaziovii, was collected from a tree cultivated in Rio de Janeiro, which, acording to the label, apparently originated from a tree cultivated in Ipiranga, São Paulo. Confusingly, Glaziou (1913) cited his $18145 a$ for both C. glaziovii and C. erianthos.

Ceiba glaziovii has a crepuscular-nocturnal anthesis and the flowers possess copious nectar, such that bat pollination is likely, although observations are lacking.

\section{Examined specimens}

Brazil. Bahia: Curaça, Fazenda Mina, $9^{\circ} 13^{\prime} S$, 39'55'W, 10-VIII-1983, S. da Silva \& G. Pinto 274 (GUA, MBM). Estrada Campo Formosa-Delfino, 13VIII-1999, E. Melo 2788 (HUEFS). Jacobina, 25-VI1999, F. França (HUEFS, UEC); ibidem, Barracão de Cima, 6-VII-1996. R. Harley \& al. 3444 (K, SPF). Paratú $12 \mathrm{~km}$ to Serrinha, VIII-1961, C.L. Pabst (HB). Retrolândia, $9 \mathrm{~km}$ from the city, 16-IX-1999, $R$. Oliveira 258 (HUEFS). Rodovia Lomanto Jr., km 71, Capim GrossoJuazeiro, 20-VIII-1979, R. Monteiro, R. Martins \& K. Yamamoto 10182 (E, UEC). CEARÁ: Crato, 13-VIII-1948, 


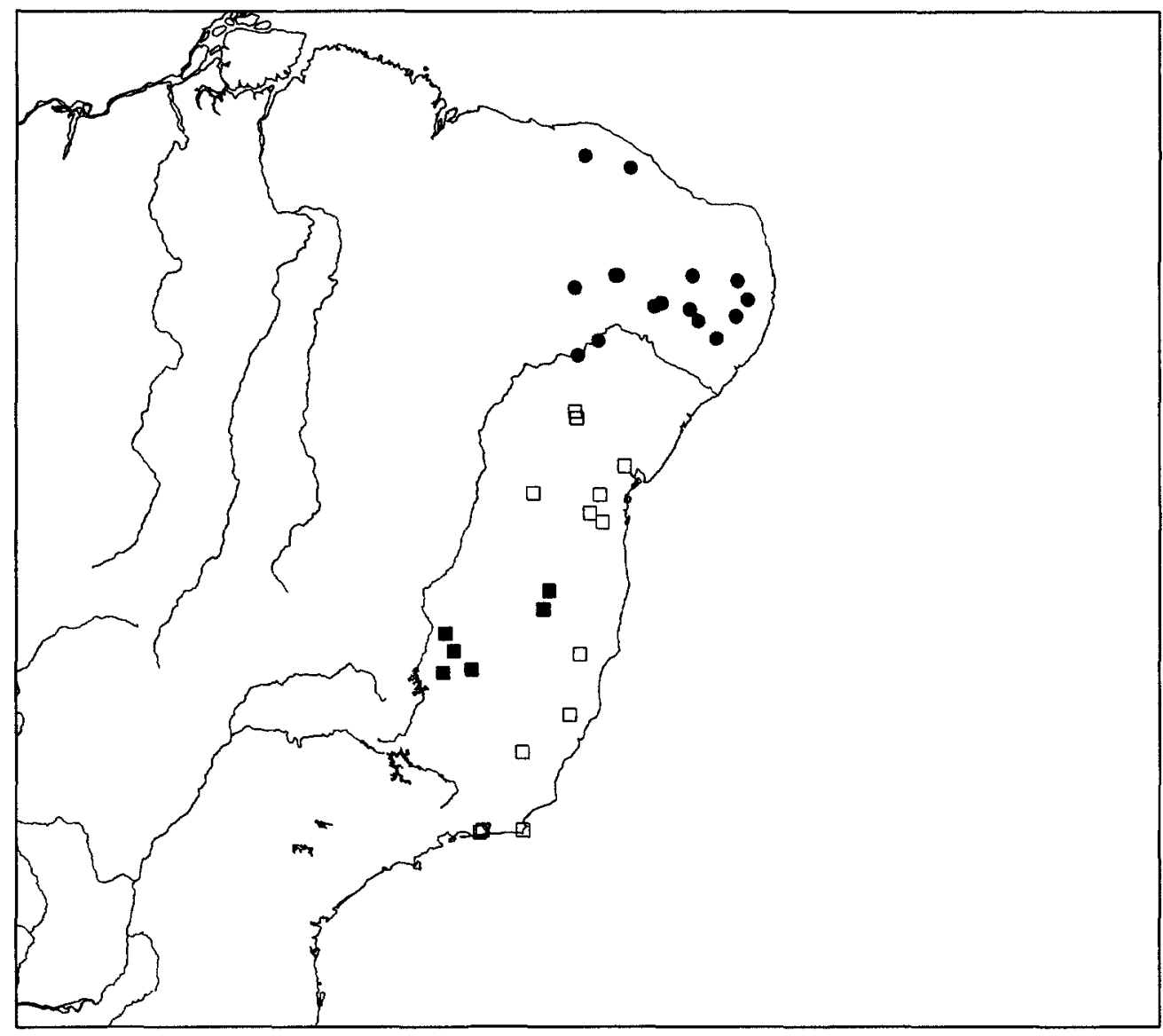

Fig. 4.-Distribution map of $\square$ Ceiba erianthos, C. glaziovii and $\square$ C. jasminodora.

Duarte \& Ivone 1455 (RB). Entre Barbalho e Crato, 21VII-1964, A. Castellanos 25198 (RB, MUS). Serra de Meruoca, NW of Sobral, VIII-1988, A. Fernández, $P$. Gibbs \& J. Mattes (EAC). Serra do Baturité, Pacoti, VIII-1957. T. Guédes s.n. (IPA, RB). Serra dos Bezouros, 30-VIII-1957, T. Guédes 607 (RB, UB). Paraiba: Texeira. $7 \mathrm{~km}$ estrada PB238 to Desterro, 15-IX-1984, W. da Fonseca \& M. Santos 429 (RB, SPF). PERNAMBUCO: Arcoverde, 16-VII-1955, D. Andrade-Lima 55-2093 (IPA). Alagoinha, 16-IX-1991, A. Bocage 198 (IPA). Araripa. 27-VII-1993, A. Bocage 257 (IPA). Bom Jardim, 12-XII1983, D. Andrade-Lima \& R. Barreto P26 (IPA). Brejino, 17-IX-1991, A. Bocage 203 (IPA). Carurú. 19-IX1991, A. Bocage 226 (IPA). Custódia, 11-VII-1990, A. Bocage 14 (IPA). Flores-Sta. Clara, Serra de Baixa Verde, 30-VII-1993, A. Bocage 260 (IPA). Guaranhums, II-1929, B. Pickel 2166 (IPA, NY, WIS). Jataúba, 21-X1991, A. Bocage 233 (IPA). Oreira, Mata de Pau Ferro, 15-X-1980, M. Fevereiro 63 (IPA). Recife, granja de Dois Irmãos, 22-IX-1949, D. Andrade-Lima 309 (IPA). São José de Belmonte, 30-VII-1993, A. Bocage 259 (IPA). Serra Talhada, 29-VII-1993, A. Bocage 254 (IPA).
Sertânia, 18-IX-1991, A. Bocage 218 (IPA). TexeiraDesterro, 15-IX-1984, W.N. da Fonseca \& M. Santos 429 (RB). Triunfo, $07^{\circ} 55^{\prime} \mathrm{S}, 38^{\circ} 04^{\prime} \mathrm{W}, 2-\mathrm{X}-1980$, O.A. Salgado 138 (IPA, RB). Venturosa, 18-IX-1991, A. Bocage 223 (IPA).

10. Ceiba erianthos (Cav.) K. Schum. in Mart. (ed.), Fl. Bras. 12(3): 211 (1886)

Bombax erianthos Cav., Diss. 5: 294, tab. 152

fig. 1 (1788); Xylon erianthos (Cav.) Kuntze, Revis. Gen. Pl. 1: 75 (1891); Eriodendron leiantherum DC., Prodr. 1: 479 (1824), nom. illeg.

Ind. loc.: "Habitat in Brasilia prope S. Sebastianum. Commersonius reperit. V. S. unicum exemplar apud D. de Jussieu"

Type: Brazil. Prope S. Sebastianum, Commerson s.n. (lectotype, here designated, P-Juss.!) 
Trees around $10 \mathrm{~m}$ with aculeate trunk and branches including young flowering branches which bear dense, small, aculeate spines. Leaves 5-7 foliolate, petioles $45-120 \mathrm{~mm}$ long; leaflets $34-85 \times 16-40 \mathrm{~mm}$, chartaceous, oblanceolate, apex acute, mucronate, glabrous petiolules c. $5 \mathrm{~mm}$ long. Flowers axillary, borne singly or in fascicles. Pedicels c. 20-25 mm long, stout. Calyx 20-30 × 11$14 \mathrm{~mm}$, broadly campanulate, glabrous externally. Petals $65-90 \times 18-22 \mathrm{~mm}$, more or less spathulate, white, densely lanate-villous externally, glabrous internally, with sparse carmine striations distally, becoming uniformly carmine towards the base. Lower staminal tube c. $10 \mathrm{~mm}$, densely hairy and with a swelling but no staminal appendages, continuing united for c. $15 \mathrm{~mm}$ and then dividing into 5 filaments which bear elongate sinuate anthers. Ovary subglobose, with slender glabrous style bearing a globose, pinkish stigma c. $10 \mathrm{~mm}$ or more above level of anthers. Fruit rather narrowly elongate- ellipsoidal capsule, c. $14 \times 5 \mathrm{~cm}$.

Flowering March-July. Restinga and dry coastal forest, usually on rocky outcrops. SE and E Brazil (Rio de Janeiro, E Minas Gerais, Espírito Santo and Bahia) (fig. 4).

Illustrations. SANTOS (1969, fig. 5; LORENZI (1998: 43).

Crepuscular anthesis with bat pollination. The densely tomentose petals of this species are distinctive although some care is needed with herbarium material to distinguish from specimens of $C$. glaziovii.

\section{Examined specimens}

BRAZIL. BAHIA: Abaíra, 7-VII-1992, W. Ganev 624 (K, HUEFS, SPF); ibidem, 15-V-2000, E. Miranda Silva 503 \& al. (HUEFS); B. Bomomeira, Vale dos Rios Paraguaçu e Jacuipe, X-1980, P. de Cavalo 808 (IPA). Ipiaú-Jequié, 9-III-1967, R.P. Belém \& R.S. Pinheiros 3397 (CEPLAC, US). Ipirá, Fazenda Recreio, 4-X-1986, $L$ de Queiroz \& al. 963 (HUEFS). Itatim, Morto das Tocas, 31 -VIII-1996, F. Franca \& al. 1783 (HUEFS); ibidem, Morro do Agenor, 29-VIII-1996, E. de Melo, $F$. Franca \& C. Correia 1627 (HUEFS). Jequié, 8-VII1971, R.S. Pinheiro 1459 (CEPEC). Jussiape-Campinho, near Jussiape, 10-VIII-1997, A.M. Giulietti 1305 \& R. Harley (HUEFS). Manuel Vitorino, BR 116 Riberão

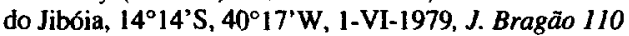

(JB). Montagne de la Jacobine (Serra Jacobina), 1836, Blanchet 2617 (F). NE of Bananeiras, II-1981, P. de Cavalo 1081 (HUEFS). Mucugê, near João Corrêa, 14-VI$2000, R$. Harley \& A.M. Giulietti (HUEFS). $10 \mathrm{~km}$ from Capoeira, 7-VII-19762, R.S. Pinheiro 1875 (CEPLAC, NY, UEC). EsPIRITo SANTO: Colatina-Vitória, 9-VI1968, R.P. Belém 3825 (CEPEC, NY). MinAs GERAIS:

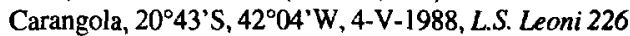
(BRAD, MUS). Nanuque, 30-VI-1968, R.P. Belém 3792 (CEPLAC, NY). Parque Estadual do Rio Doce, Marliéria, 20-V-1999, R. Bortoluzzi 657 (BHCB). Rio Branco, road to São Geraldo, 25-XI-1930, I. Mexia 5354 (F, G, NY, U). Varzelândia, caatinga entre Rio Verde e Brezo de Metambal, 19-VII-1968, D. Andrade-Lima 5436 (IPA). RIO DE JANEIRO: Barra de Tijuca, 27-V-1961, G.F. Pabst 5606 (MBM); ibidem. Morro do Focinho de Cavalo, 18-IV-2001, C.A. de Oliveira s.n. (GUA). Botafogo, 9-V-1869, A. Glaziou 3769 (P). Cabo Frio, restinga praia Tucuns, 15-V-1993, J. Pirani 2881 \& R. Mello Silva (SPF). Estrada Jacarepaguá-Pedra Blanca, 11-V-1963, Lanna 629 \& Castellanos (F). Guanabara, 3V-1974, R.F de Oliveira s.n. (NY). Ilha Bonita, Bahia Sepetiba, V-1974, J. F. Silva s.n. (RB). Ilha de Paquetá, 17-VII-1915, J.N. Rose \& P.G. Russell 20296 (NY). Itaipu, Morro das Andorinhas, 14-V-1980, D. Araujo 3758 (GUA). Pedra da Itauna, 29-VII-1971, D. Sucre 7578 (RB). Rio de Janeiro, C. Gaudichaud 955 (F, G). São Cristovão, 12-V-1893, A. Glaziou 239a (P). Tijuca, VI-1924, J.G. Kuhlman 7732 (F).

11. Ceiba jasminodora (A. St.-Hil.) K. Schum. in Mart. (ed.), Fl. Bras. 12: 213 (1886)

Eriodendron jasminodorum A. St.-Hil., Fl. Bras. Merid. 1: 265, tab. 52 (1828)

Ind. loc.: "Minas Gerais: Quartel de San Miguel (Minas Novas)"

Type: Brazil. Minas Gerais, Quartel de San Miguel, Minas Novas. Saint Hilaire s.n. (lectotype, here designated, P!)

Ceiba sipolisii K. Schum. \& Schwacke, Bot. Jahrb. Syst. 25, Beibl. 60: 16 (1898)

Ind. loc.: "In Brasiliae civit. Minas Gerais ad Biribiry prope Diamantina, ab Abbé Sipolis detecta. Schwacke 8324; Glaziou 18893 et 20206."

Type: Brazil. Minas Gerais, Glaziou 18893 (lectotype, here designated, P!)

Usually small trees 1-2 $\mathrm{m}$, but around $4 \mathrm{~m}$ in cultivation, with aculeate branches. Leaves 3foliolate, petioles $20-45 \mathrm{~mm}$ long; leaflets 55 $120 \times 36-60 \mathrm{~mm}$, ovate to broadly lanceolate, entire, coriaceous, acute or somewhat rounded, with very slender mucron c. $3 \mathrm{~mm}$, glabrous, with petiolules $3-5 \mathrm{~mm}$ long. Flowers borne 


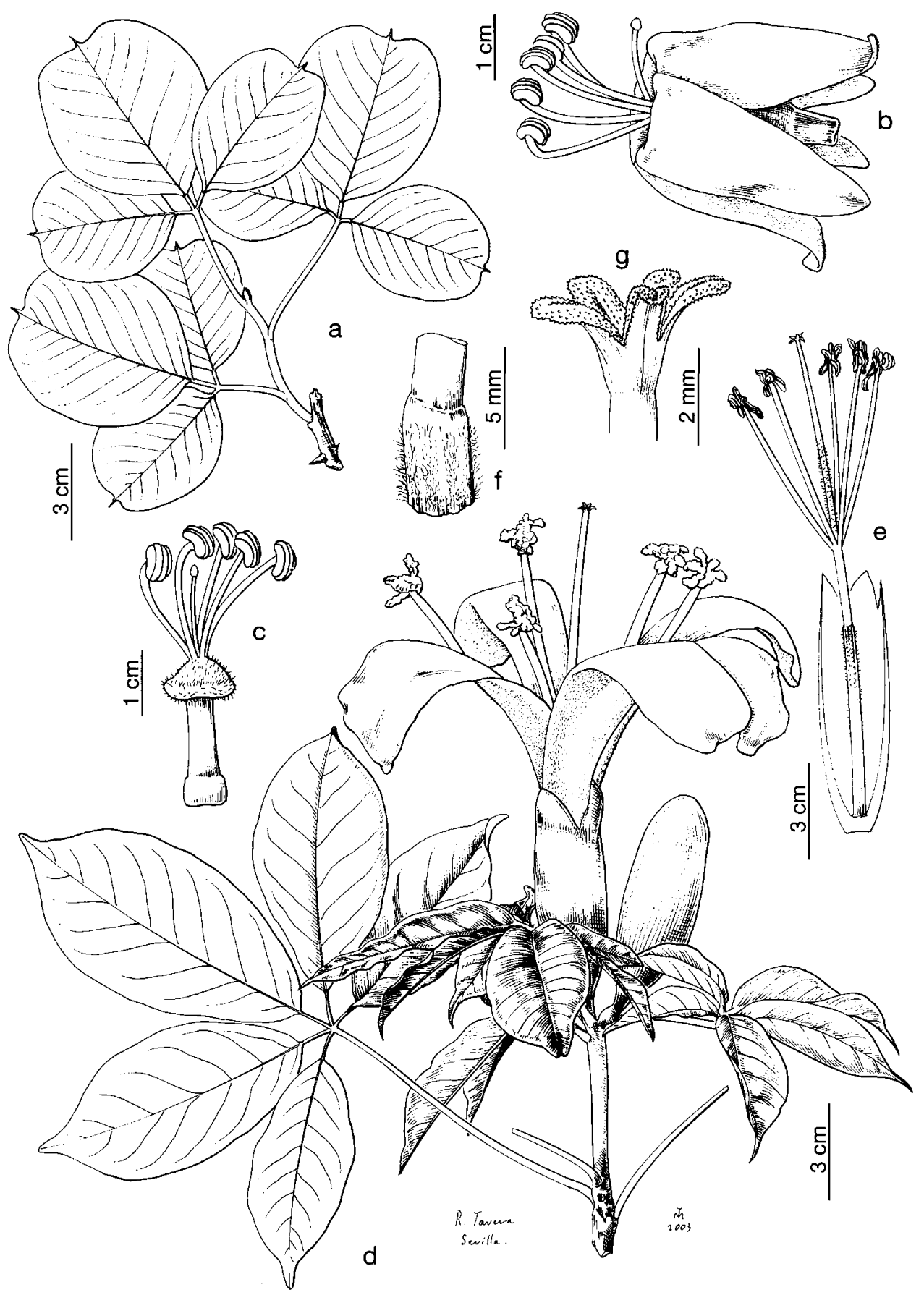

Fig. 5.-Ceiba jasminodora (Semir 10929, UEC): a) branch with leaves; b) flower at anthesis; c) androecium. C. samauma (Nee 33868, E): d) branch with leaves; e) androecium; f) detail of median zone of staminal tube; g) stigma. 
singly in the axils of leaves. Pedicels $10 \mathrm{~mm}$ long, slender. Calyx c. $8 \times 6 \mathrm{~mm}$, campanulate, glabrous-puberulent externally. Petals 18-25x $7 \mathrm{~mm}$, cream, markedly reflexed. Staminal column 6-7 mm, glabrous, with appendages in the form of a sparsely hairy disc which is bordered by dense fringe of hairs; 5 free staminal filaments c. $8-12 \mathrm{~mm}$, bearing small (c. $2.5 \mathrm{~mm}$ ), anfractuose anthers. Ovary pyriform, with a slender style bearing a white globose stigma at the level of the anthers. Fruit an ellipsoidal capsule c. $8 \times 5 \mathrm{~cm}$.

Flowering April-July. Campo rupestre (rocky upland vegetation). Brazil, endemic to the southern Serra de Espinhaço and associated uplands in Minas Gerais (fig. 4).

Illustrations. SANTOS (1964, p. 171, Fig. 6, sub C. sipolisii) (fig. 5).

The small cream flowers of this species may open at dusk, and so probably with moth pollination.

\section{Examined specimens}

Brazil. Minas Gerais: Aracaí, 15548, C.M. Magalhães (RB). Conselheiro Mata, V1-1934, B. Brade 496 (RB); ibidem, 4-VI-1985, F. de Barros 1084 (SP). Diamantina, 20-26 km WSW of city, 18-V-1990, M. Arbo \& al. 4363 (SPF); ibidem, Glaziou 2026 (K, P). Diamantina para Couto Magalhães, 18-VI-2000, F. Costa \& P. Fiaschi 194 (SPF). Grão Mogol, vale Rio Itacambiruçu, 14V-1998, J. Pirani 4320 \& al. (SPF). Itaobim, vale de Jequitinhonha, 2-IV-1979, C.T. Rizzini \& A. Mattes 1120 (RB). Itaobim-Arocuás, 2-IV-1959, C.M. Magalhaes 15548 (RB, UB). Itinga, 12-X-1984, C.T. Rizzini s.n. (RB). Joaquim Felício, Balneário Varedas, 19-V-2001. M. Groppo Jr. 804, M. Maracatoa \& P. Soffiiato (SPF); ibidem, estrada para Serra do Cabral, 8-VII-200I, Fiaschi 876. A. Lobão \& F. Costa (SPF). Medina. 1995, A. Brina s.n. (BHCB). Pedra Azul-André Fernandes, BR km 38, 29-I-1980, J. Semir 10929 (UEC). Presidente Kubitschek, rodovia Datas-Serro, 1-III-1998. J. Pirani 4078 \& al. s.n. (SPF). Serra do Cabral, 28-VII-1976, P.E. Gibbs \& al. 2508 (E, UEC); ibidem, $5 \mathrm{~km} \mathrm{~N}$ of Corinto near Buenopólis, 15-V-1977, P.E. Gibbs. R.J. Abbott \& J.B. Andrade 5149 (UEC). Serra do Espinhaço, 3.5 km SW of Rio Jequití and Medanha, 14-IV-1973, H.R. Anderson 8899 (NY, MO, UEC).

12. Ceiba trischistandra (A. Gray) Bakh., Bull. Jard. Bot. Buitenzorg ser. 3, 6: 196 (1924)

Eriodendron trischistandrum A. Gray, U.S.

Expl. Exped., Phan. 1: 182 (1854)
Ind loc.: "Peru. Garden at Lima (Wilkes Expedition)"

Type: Peru. Cultivated tree in Lima, Wilkes s.n. (lectotype, here designated, US digital image!)

Trees 15-30 $\mathrm{m}$ with aculeate trunk. Leaves 5-7 foliolate, petioles $100-180 \mathrm{~mm}$ long; leaflets $55-125 \times 30-55 \mathrm{~mm}$, coriaceous, broadly oblanceolate to obovate, entire or obscurely denticulate, acute, glabrous or with sparse appressed hairs along midrib extending to the lamina, with petiolules $2-3 \mathrm{~mm}$ long. Flowers axillary, solitary or fascicles of 2-3. Pedicels $10-30 \mathrm{~mm}$ long. Calyx $23-30 \times 20$ $26 \mathrm{~mm}$, broadly campanulate, four lobed, glabrous or finely velutinous, crimson. Petals c. $45-60 \times 23 \mathrm{~mm}$, narrowly obovate to spathulate, densely tomentose externally except at the margins, internally mostly glabrous, white, externally tinged green, somewhat reflexed at anthesis. Stamens arising from a short c. $5 \mathrm{~mm}$ hairy collar, initially as 5 filaments, but each splitting for the distal $15 \mathrm{~mm}$ into 3 short filaments which terminate in versatile, monothecate, anfractuose anthers. Ovary pyriform, with style bearing the stigma usually above the level of the anthers. Fruit elongate-ellipsoidal capsule c. $12 \times 8 \mathrm{~cm}$.

Flowering April-July. Dry valleys of Pacific coast. S Ecuador and N Peru (fig. 3).

A very striking species with its red calyx, densely white tomentose petals, and further fission of the five stamen filaments. Curiously the original collection of this species was from a cultivated tree in Lima city, and its transference to Ceiba by BAKHUIZEN VAN DEN BRINK (1924) was also based on flowers from cultivated trees in Java (Indonesia). The species was still unknown in its natural habitat when MACBRIDE (1956), in the Flora of Peru, noted: "Type from a garden in Lima; also in Java, country of origin unknown." C. trischistandra is another species presumably with crepuscular anthesis and bat pollination.

\section{Examined specimens}

ECUador. Guayas: Capara, $21 \mathrm{~km}$ Guayaquil to Dante. C.H. \& P.M. Dodson 11322 (MO). Esterosalado. near bridge on highway to Salinas, 12-VI-1955, E. As- 
plund 16607 (G, K, NY, S), Guayaquil, 13-VI-1943, E.L. Little Jr. 6594 (K). Guayaquil-Salinas, $2^{\circ} 25^{\prime} \mathrm{S}, 80^{\circ} 22^{\prime} \mathrm{W}$, 17-VII-1989, L.J. Dorr \& I. Valdespino s.n. (NY). Guayas-Guayquil, IX-1963, Valverde 326 (MO). LoJA: Pupacos, nr. Zapotepamba. W. of Catacocha, 30-IV1996, G.P. Lewis \& al. 2270 (K). Valle Seco de playas, 19-IV-1944, M. Acosta Solís 7976(F). MANABí: Bahia de Caraquez, E. Asplund 16562 (NY.S). $10 \mathrm{~km} \mathrm{NW}$ of Puerto Viejo, 30-VII-1977, C.H. \& H.C. Dodson 6789 (MO). $11 \mathrm{~km}$ W of Puertoviejo, 28-X-1974, A. Gentry, F. OrtizCrespot \& R. Narváez 12201 (MO, S).

PeRu. Tumbes: Ca. $10 \mathrm{~km}$ S of Canchaque, 26-V1957, H. Ellenberg 1612 (U). N of Tumbes, 13-VI-1957, H. Ellenberg 1382 (U).

13. Ceiba pentandra (L.) Gaertn., Fruct. Sem. Pl. 2: 244, t. 133 fig. 1 (1791)

Bombax pentandrum L., Sp. Pl.: 511 (1753); Eriodendron anfractuosum DC., Prodr. 1: 479 (1824), nom. illeg.; Bombax occidentalis Spreng., Syst. 3: 124 (1826), nom. illeg., Ceiba occidentalis (Spreng.) Burkill, Kew Bull. 1935: 317 (1935) nom. illeg., Ceiba anfractuosa M. Gómez, Fl. Habanera: 141 (1897), nom. illeg.

Ind. loc.: "Habitat in Indiis"

Type: lectotype, designated by Nicolson (1979), in Rheede, Hort. Malab. 3, tab. 50 (1682)

Bombax mompoxense Kunth in Humb., Bonpl. \& Kunth, Nov. Gen. Sp. 5: 300 (1822)

Ind. loc.: "Crescit ad ripam fluminis Magdalenae, prope Mompax, Nova granatensium, alt. 70 hex."

Type: Colombia. without locality, Humboldt \& Bonpland s.n. (lectotype, here designated, P!)

Bombax cumanense Kunth in Humb., Bonpl. \& Kunth, Nov. Gen. Sp. 5: 300 (1822)

Ind. loc.: "Crescit prope Cumana (Nova Andalusia)"

Type: Venezuela. Cumaná [added later by another hand], Humboldt \& Bonpland s.n. (lectotype, here designated, $\mathrm{P}$ !)

Tall emergent trees up to $50 \mathrm{~m}$ or more, trunk usually aculeate, sometimes with prominent buttresses. Leaves 5-8 foliolate, petiole c. 120-150 mm long; leaflets 110-200 $\times 25-50 \mathrm{~mm}$, narrowly elliptical to oblanceolate, base cuneate to somewhat truncate, apex acuminate, margin entire or obscurely dentic- ulate, glabrous, petiolule $5-30 \mathrm{~mm}$ long. Flowers fasciculate on the stems. Pedicel c. $20 \mathrm{~mm}$ long. Calyx 12-15 $\times 11-13 \mathrm{~mm}$, campanulate, glabrous. Petals $22-46 \times 6-$ $13 \mathrm{~mm}$, white or pinkish, externally densely sericeous sometimes with brownish hairs, sparsely so at the overlapping margins. Staminal tube variable: either c. $3.5 \mathrm{~mm}$, with an abrupt, truncate termination, and then with 5 free white or markedly pinkish filaments arising directly or nearly so, or tube tapering for $5-14 \mathrm{~mm}$ before splitting into 5 filaments, with no staminodial appendages; anthers small, markedly anfractuose. Ovary pyriform with stigma usually exserted above the anthers. Fruit ellipsoidal to pyriform capsule 15$18 \times 8-10 \mathrm{~cm}$.

Flowering August to September. Distribution effectively pan-tropical but almost certainly introduced in Asia and the Pacific, although probably native, at least in part, in W Africa (cf. BAKER, 1965). We have not attempted to study this species in any detail outwith the Americas (fig. 6).

Illustrations. ADAMS (1972: 151, fig. 56); LORENZI (1992: 60).

NiCOLSON (1979) provided an extensive commentary on the typification of the genera Bombax, Ceiba and Cochlospermum. He concluded that Bombax pentandrum L., which was based on a mixture of (mostly) asiatic but also some New World elements, must be typified by one of the illustrations in Rheede Hort. Malab., and lectotypified this species with figure 50 in this work. The illustration proposed by NICOLSON (1979) clearly depicts flowers of $C$. pentandra, and a plant with narrowly elliptical leaflets, but most leaves have eight (or more) leaflets instead of the 5-7 common in this species.

BAKHUIZEN (1924) provided a detailed synonymy for Ceiba pentandra (L.) Gaertn., and he distinguished two varieties, var. caribaea (DC) Bakh., which included the New World and African forms, and var. indi$c a$ (DC) Bakh. (= var. pentandra) for the asiatic plants. However, BAKER (1965) pointed out that most authors who recognize infra- 
specific, or even specific, variants for $C$. pentandra, distinguish between the New World and African forms. Both BAKHUIZEN (1924) and BAKER (1965), on the basis of their detailed studies of this taxon, concluded that $C$. pentandra should be recognized as a single rather polymorphic species, a view which we adopt here.

In Amazonian Brazil, $C$. pentandra often occurs as a tall emergent tree of varzea vegetation, although it also thrives (sometimes al- most certainly as planted specimens) in seasonally dry areas in Central America. This ability to grow both in riverine flood plain conditions and also in mesic, seasonally dry areas is found in some other species of diverse families, e.g. Triplaris gardneriana Wedd. (Polygonaceae), Pachira aquatica (Bombaceae) [J. Ratter, pers. comm.].

Even as represented in the in the New World, $C$. pentandra is another very variable Ceiba species, possibly with distinct infraspe-

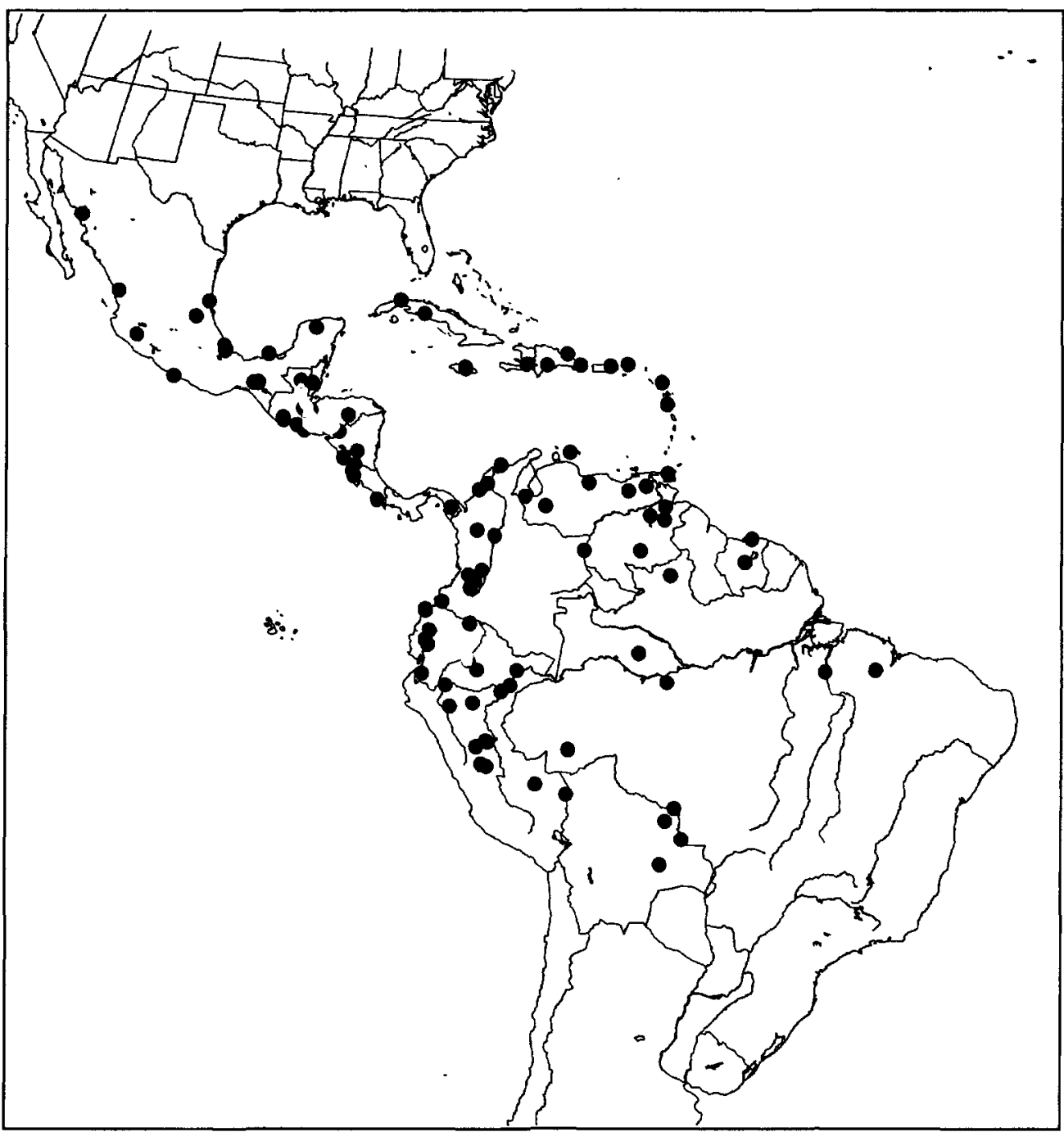

Fig. 6.-Distribution map of Ceiba pentandra (New World only). 
cific taxa. Plants with 'typical' leaves, i.e. narrowly oblong to narrowly elliptical, with distinct petiolules c. $10 \mathrm{~mm}$, which correspond to Bombax cumanense (represented by a sterile specimen in the Humboldt \& Bonpland herbarium at P), and which occur in Venezuela, and the Caribbean (e.g. Zanoni \& al. 10817 from the Dominican Republic) look rather different from others with oblanceolate leaves which taper to short, $2-5 \mathrm{~mm}$ petiolules, and which correspond to Bombax mompoxense (again represented by a sterile Humboldt \& Bonpland specimen at P) and characterised by, e.g. Gentry \& Rentería 24534 from the Chocó in Colombia.

And there are also striking differences in petal size and colour (white to distinctly pink), and the size and form of the staminal tube, and whether the free filaments are white or markedly pink. Two kinds of lower staminal tube are found: one has the tube around $6 \mathrm{~mm}$ and tapering to the level where the 5 free filaments arise. Examples occur in both $S$ America and the Caribbean, e.g. Little 9431 (Colombia) and Bodim 8005 (Puerto Rico). The other has a much shorter tube, around 2$3 \mathrm{~mm}$ which terminates abruptly to give a truncate ledge from which the free filaments arise. This form is mainly restricted to $S$ America, e.g. Froes 1997 (Maranhão, Brazil) and Krukoff 5646 (Acre, Brazil). However, some specimens, e.g. Zanoni 10817 (Dominican Republic) and Hermans 700 (Cuba) combine these features with a short truncate tube from which arises a short tapering tube which then gives rise to the 5 free stamens.

Given the general lack of specimens with both leaves and flowers, and the apparent absence of consistent geographical correlation with e.g. flower size and length of staminal tube, and also recognizing the long anthropomorphic interaction with this species, which has certainly influenced its distribution and possibly some morphological attributes, we prefer at this time to maintain a single variable species.

Ceiba pentandra is a species with nocturnal anthesis, copious nectar, and bat pollination. In the Manaus area of central Amazonian Brazil some four species of bats were ob- served to visit this species (see GrIBEL \& al., 1999). In this area, flowers also have diverse diurnal morning visitors (birds, monkeys) seeking residual nectar, but since the styles abscise by $10 \mathrm{am}$, it is the nocturnal pollinators which produce fruits. BAKER \& HARRIS (1964) also reported bat pollination for $C$. pentandra in W Africa. The nocturnal anthesis, and the imposing height of the trees, means that most herbarium specimens consist of old flowers that have fallen to the ground.

\section{Examined specimens}

\section{Central America}

BeLIZE. Rio Grande, 9-II-1934, W.A. Schipp 1235 (G, NY, S). 1 mile S of Belmapan, 27-VII-1970, D. Speltman \& W. Newey 1899 (E).

Costa RICA. Guanacaste, Paso Temisque, 8-VIII1932, H.E. Stork 4011 (NY).

EL SALVADOR. La Libertad, coast road W of [illegible], 28-I-1959, P.H. Allen 7203 (LL).

GuATEMALA. Escuintla, $8 \mathrm{~km}$ E Sta. Lucía, 8-V-1975, Ellis \& Dunn 1154 (NY). Gualan, along Motagua River, 8-I, B.L. Robinson 219 (NY). Jalapa, near Guastatori, 6-I1908. W.A. Kellerman 7976 (NY). Peten, Uaxactum, 1IV-1931, H. Bartlett 12432 (NY, S).

Mexico. ChiAPAS: Alcala-Pugiltik, 20-II-1968, A.S. Ton 3754 (LL). Chiapilla-San Lucas, R. Laughlin 2858 (CAS). Terán, $4 \mathrm{~km}$ N of Juan Crispín, 17-XII-1972, D.E. Breedlove \& R.F. Thorne 30388 (NY). $3 \mathrm{~km} \mathrm{E}$ of Chiapa de Corzo, 8-I-1972, D.E. Breedlove 23574 (LL). 13$15 \mathrm{~km} \mathrm{~S}$ of Ocozocoautla, 4-I-1972, D.E. Breedlove \& E. McClintock 23460 (CAS). GUERRERO: Acapulco de Juárez, X/III-1894/5, E. Palmer 603 (NY). JALISCO: Acaponeta, II-1895, F.H. Lamb 525 (NY). Tuxpan, 6-XI1926, Y. Mexia 1068 (CAS, G, NY). SAN LuIS Potosf: Tamazunchale, 28-VII-1937, M.T. Edwards 688 (TEX). SONORA: Esperanza, 21-I-1949, E. Matuda s.n. (CAS). Hermosilla, 4-III-1919, J.N. Rose 12372 (NY). TAMAULIPAS: Tampico, 1/31-I-1910, E. Palmer 103 (CAS). VeracruZ: Jalapa, 9-III-1968, T.D. Pennington \& J. Sarukhan 9527 (NY). Medellín-Los Robles, 22-II1984, M. Nee \& K. Taylor 29623 (NY). Veracruz-Nautla, 20-X-1967, T.D. Pennington \& J. Sarukhan 9250 (NY). YUCATAN: Without precise locality, 1917-21, G. Gaumer 24207 (E, G).

Panama. "Plants of Panama" sin loc., 1892, S. Hayes s.n. (E).

\section{CARIBBEAN IsLandS}

Cuba. Havanna-Santiago de las Vegas, 8-III-1905, H.A. Herman 700 (NY). Manicaragua, near Soledad, A. Gonzales 501 (NY, S). Río San Juan, Sta. Clara, 24-III1910, N.L Britton. F.S. Earle \& P. Wilson 5961 (NY). Sevilla Este, near Santiago, 31-VIII-1906, N. Taylor 134 (NY). Soledad, Cienfuegos, 1-II-1927, J.G. Jack 4782 (NY, S).

CuRAÇAo. Groot St. Martha, 9-1I-1955, M. Amaldo $1966(\mathrm{U})$ 
DOMINICAN REPUBLIC. $15 \mathrm{~km}$ from La Romana, 5 - II1981, T. Zanoni, M. Mejia \& C. Ramírez 10817 (NY). Península Samaná, 20-III-1984, T. Zanoni, J. Pimental \& R. García 29306 (NY). Santo Domingo, Azua, 20-III1913, J.N. Rose, W.R. Fitch \& P.G. Russell 407I (NY).

HaITI. Dessalines, 14-III-1925, E. Ekman s.n. (S). Massif de la Sedlle, Petionville, V-1925, E. Ekman 5421 (S). St. Marc, 30-III-1920, E.C. Leonard s.n. (NY).

JAMAICA. Moneague, 13-III-1850, R.C.Alexanders.n. (NY). St. Andrews parish near Cross Roads, 14-III-1969, G. Proctor 29999 (U). St Catherine parish, N Watermount, 17-III-1972, G. Proctor 32859 (U). St. Elizabeth, 5-II-1961, G.R. Proctor \& W. Mullingo 21973 (NY).

LEEWARd ISLANDS. ANTIGUA. St. Mary's, 10-II-1913, J.N. Rose, W.R. Fitch \& P.G. Russell 3400 (NY). DoMINICA. Woodlands on N River watershed, 22-VI-1969, W. H. Hodge 543 (NY). SaINT Martin. St. Martin island, 19-VIII-1908, I. Boldingh 1751 (U). VIRGIN ISLANDS. Virgin Gorda, 22-VI-1969, E.L. Little 23853 (NY).

Puerto Rico. Coamo Springs, 7-II-1922, N.L Britton. E.G. Britton \& M.E. Brown 5916 (NY). Coco Beach. $18^{\circ} 22^{\prime}$ N. $65^{\circ} 48^{\prime}$ W, 14-I-1988, M. Boom 8005 (NY). Lajas, 20-II-1932, N.L. Britton \& E.G. Britton 9916 (NY).

SOUTH AMERICA

Bolivia. Santa CruZ: $3 \mathrm{~km}$ NW of Ascensión de Guarayos, 13-VII-1991, M. Nee \& G. Coimbra 41688 (NY).

Brazll. ACrE: Basin of Rio Purus, $9^{\circ} 21^{\prime}$ 'S, $69^{\circ} 00^{\prime} \mathrm{W}$, 25-VIII-1933, B. Krukoff 5648 (F. MO, NY, S, U). MARANHÃO: Estrada Santarem-Cuibá BR165. km 190, 28-X-1975, W. Rodrigues \& D. Coelho 6365 (INPA). Rio Maracassumé, 20-XI-1932, R. Froes 1997 (G, MO, S, U). PARÁ: Tucuri. Rio Tocantins, 9-XI-1980, P. Lisboa \& al. 1541 (NY). RoRaIma: Margens do Rio Uraricoeira, 22-V-1987, B.W. Nedlson \& P.S. Mera 1556 (INPA).

Colombia. Antioquia: Río León, S.A Cain 4 (COL). Río Cauca at Puerto Valdivia, 1942, J. Cuatrecasas 30037 \& R.D. Metcalf (NY, MO). BolívaR: Entre Juan Arias y Magangué, R. Romero Castañeda 9830 (COL). Magangué, 18/19-I-1919, F.W. Pennell 3942 (NY). Chocó: $50 \mathrm{~km}$ E Quibdo, 20-I-1979, A. Gentry \& E. Renteria 24534 (MO). $8 \mathrm{~km}$ de Solano, Río Caqueta, E.L. Little 9761 (COL). CundinamarCA: $28 \mathrm{~km} \mathrm{NW}$ Guadas, 5-III-1977, A. Gentry \& al. 18066 (COL, MO, NY). HulLA: Cordillera Oriental, 9-II-1945, E.L. Littlejohn 9431 (COL, NY). El Gigante, E. Pérez Arbeláez 2472 (COL). El Valle: Cali, J. Cuatrecasas 15255 (COL). Piendamor-Popayán, 11-IV-1939, A.H. Alston 7964 (NY). Río Cajambre, Costa de Pacífico, 5/15-V1944, J. Cuatrecasas 17598 (F). MaGdalena: Gamarra, 26-XI-1926, E.P. Killip \& A.C. Smth 14726 (NY). Santa Marta, 1898-99, H.H. Smith 1887 (E, MO, S). Valle de Magdalena, 1866, S. Triana s.n. (G). TolimA: El Boquerón, 14-VI-1966, J.W. Walker 258 (NY).

ECUADOR. El ORO: Hualtaco-Arenillas, LA. de Escobar 916 (TEX). Pinas-Sta. Rosa, 7-X-1979, C. Dodson, A. Gentry \& G. Shupp 8900 (MO). $15 \mathrm{~km} \mathrm{~S}$ of Piedras, 21-VI-1943. E. Lirtle 6676 (F). EsmERALDAs: Río Hoja Blanca con Río Hualpi. 14-IX-1957, E.L. Little, \& R.G. Dixon 21063 (NY). Timbre, 30-V-1955, E. Asplund 1655 (S). Los Rios: Pichilingue, 22-V-1943, E. Little 6949 (F). Río Palenque, 7-X-1976, C. Dodson \& A.H. Gentry 6508
(MO). Morona: Santiago, E. Little 69l (COL). PASTaZA: Napo-Pastaza, 4-IV-1956, E. Asplund 20523 (S). TunGURaHUA: Río Ulva below Baños, 10-III-1939, C.W. Penland \& R. Summers 9 (F).

Peru. Huanuco: Tingo María, Huanuco-Pucallpa, 25-IX-1945, J. Burgos 44 (F). LORETO: Andoas, 16-VIII1980, A. H. Gentry, R. Vasquez \& N. Jaramillo 29846 (MO). PASCO: Villa Rica-Puerto Bermúdez, 4-III-1982, A.H. Gentry \& D. Smith 36070 (MO).

Surinam. Brownsberg, 23-IX-1916, M. Jansen-Jacobs 2426 (U). Coppername, 6-V-1950, P. Van Royen 1050 (U). W of Paramarimbo, 22-XII-1948, A.M. Mennewga 224 (U).

VENEZUElA. ANZOÁtegul: Along Río Maravilla, E of Bergantín, 23-III-1945, J.A. Steyermark 61707 (F). ARagua: Parque Nacional de Henry Pittier, 8-I1-1973, T. Croat 21351 (MO. NY). BolfvaR: La Guaina, 1917 , H. Curran \& M. Harman 987 (F, NY). $15 \mathrm{~km} \mathrm{SE} \mathrm{of}$ El Callao, E. Little 157537 (MO). $30 \mathrm{~km}$ S of El Manteco, 8-VIII-1960, J.A. Steyermark 86943 (NY). MÉRIDA: Border between estado Bolívar and Territorio Delta Amacuro, $80^{\circ} 14^{\prime} \mathrm{N}, 61^{\circ} 44^{\prime} \mathrm{W}, 8$-IV-1967, J. Bruija 1668 (F, G, MO, S). Monagas: E of La Ormega, 24-IX-1955, J. Wurdack \& J.W. Monachino 39437 (NY). Río Amana, $6 \mathrm{~km}$ W of Sta. Bárbara, 2-IV-1945, J.A. Steyermark $61774(\mathrm{~F})$.

II. Ceiba sect. Campylanthera (Schott \& Endl.) K. Schum. in Mart. (ed.), Fl. Bras. 12(3): 207 (1886)

Campylanthera Schott \& Endl., Melet. Bot.: 35 (1832)

Type: Lectotype, here designated, C. samauma (Mart. \& Zucc.) K. Schum.

Pollen grains distinctly oblate with distinctly protruding equatorial caps and either pili/clavae or with striate muri. Staminal appendages usually absent, when present, not vascularized.

14. Ceiba samauma (Mart.) $\mathrm{K}$. Schum. in Mart. (ed.), Fl. Bras. 12(3): 210 (1886)

Eriodendron samauma Mart., Nov. Gen. Sp. PI. 1: 89, tab. 98 (1826)

Ind. loc.: "Habitat in sylvis primaevis densissimus udis sempiterno rore humentibus fluvios Japará, Madeira et Solimöens"

Type: Brazil. Amazonas, Rio Negro, ad margines Japuri, prope São João de Principe, Martius 3048 (lectotype, here designated, $\mathrm{M}$; isotypes, F-photo! MO-photo! NYphoto! P-photo!)

Ceiba burchelli K. Schum. in Mart. (ed.), Fl. Bras. 12(3): 211 (1886) 


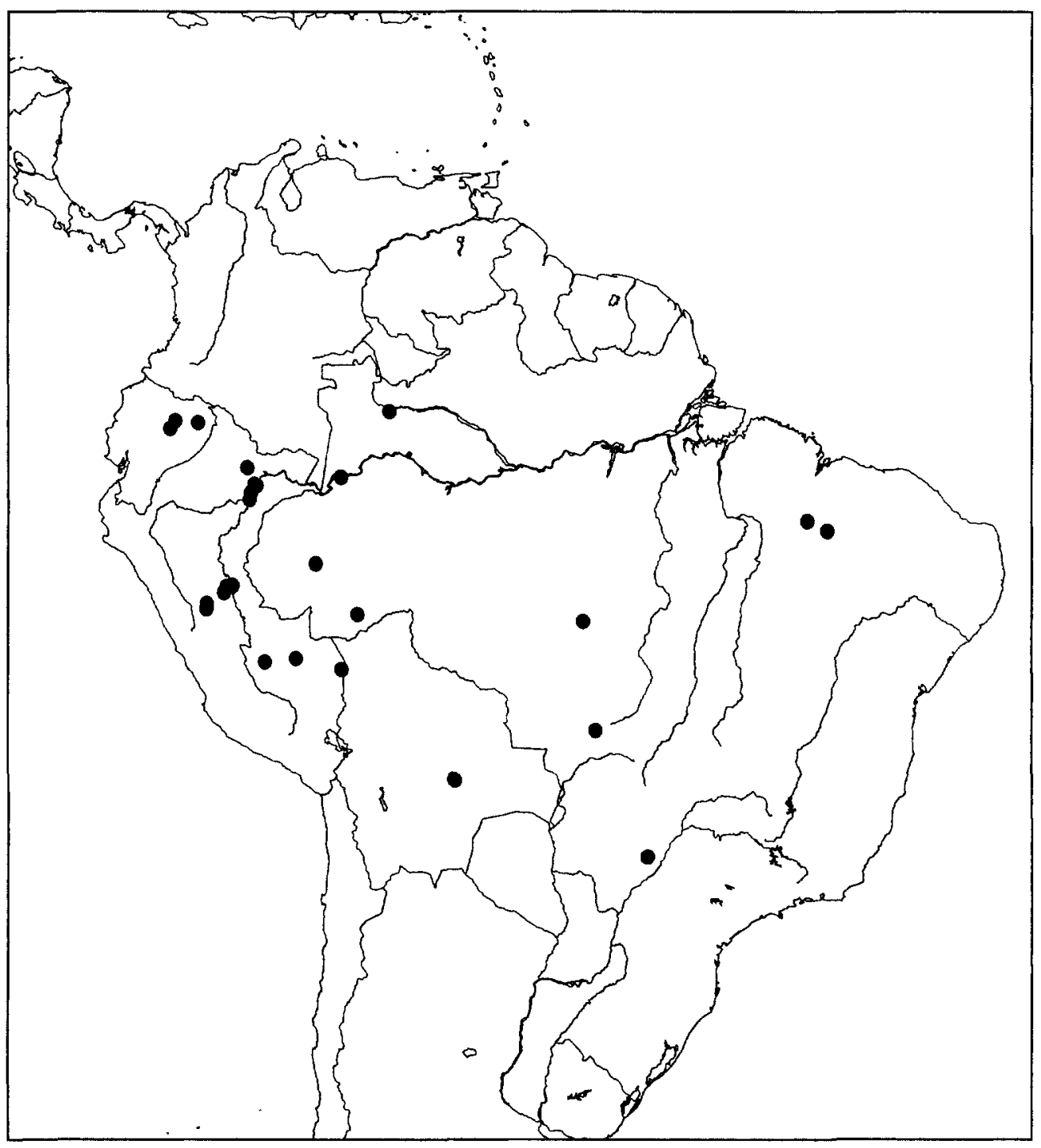

Fig. 7.-Distribution map of Ceiba samauma.

Ind. loc.: "Habitat in provincia Brasiliae Goyaz ad Porto Imperial."

Type: Brazil. Goyaz, Porto Imperial, Burchell 8514 (lectotype, here designated, NY! Fphoto!)

Trees $15 \mathrm{~m}$ or more, branches with broadbased spines but usually relatively few on trunk which may be buttressed at the base. Leaves 5 foliolate, petiole c. $50-95 \mathrm{~mm}$ long; leaflets $33-120 \times 28-55 \mathrm{~mm}$, ellipticaloblanceolate. apex acuminate, base cuneate, margin entire, glabrous, petiolule $5-7 \mathrm{~mm}$ long. Flowers axillary, borne singly or in fascicles, rather funnelform. Pedicel c. $15 \mathrm{~mm}$ long, stout. Calyx 43-67 × 17-25 mm, cylindrical-funnelform, with 5 conspicuous teeth up to $9 \mathrm{~mm}$, glabrous externally, densely villous within. Petals $100-220 \times 17-22 \mathrm{~mm}$, oblong-spathulate, whitish but with dense 
golden brown long sericeous-villous indumentum externally, internally uniformly short sericeous. Staminal tube basally $35-80 \mathrm{~mm}$, dividing without the presence of staminodial appendages or swelling to give 5 filaments 45-90 mm, bearing short setae but appearing glabrous, with large, up to $18 \mathrm{~mm}$ orange, anfractuose anthers. Ovary subglobose, with a long slender style which is densely hairy as it emerges from the staminal tube, becoming glabrous distally, stigma shortly 5-lobed. borne at same level or somewhat above anthers. Fruit ellipsoidal-pyriform capsule 15$18 \times 8 \mathrm{~cm}$.

Flowering December-March(May). Humid and riverine forest. Extending from Bolivia and Peru to Amazonian Brazil (fig. 7).

Illustrations. LORENZI (1998: 44) (fig. 5).

This is a widely distributed and probably under collected species. Flowers have crepuscular anthesis and presumably bat pollinators.

\section{Examined specimens}

Bolivia. LA PAZ: Near Calisaya, basin of Río Bopi, I22-VII-1939, B. Krukoff 10067 (F, G, MO, S). SANTA CRUz: Sta. Cruz, Fries 1349 (S). W side of Sta. Cruz (cult?). 29-I-1987, M. Nee 33868 (NY).

BrazIL. Amazonas: Bom Futuro, Rio Solimões, 4-II1937, A. Ducke 35401 (INPA, S, U). Near mouth of Rio Embira, B. Krukoff 4839 (F, G, MO, NY, S, U). MARANHẢO: Cocal Grande, $35 \mathrm{~km}$ NE Barrea do Corda. Rio Mearim. G. Schatz \& al. 873 (NY). Fortuna. along Rio Itapecuru. 22-II-1983, G. Schatz \& al. 724 (NY). Mato Grosso: Corumbá, 15-VI-1994, G.A. Damasceno \& M. Bartolotto 32168 (CPAP). Poconé. 12-1I-1990, A. Pott 5502 (CPAP), $50 \mathrm{~km} \mathrm{~N}$ of Xavantina. 9-X-1964. G. Prance \& M. Silva 59311 (NY, U). Mato Grosso SuL: Fazenda Urubu, 26-XI-1993, V.J. Pott 2132 (CPAP, UEC). João do Couto, Chapada dos Veiadeiros (cult?), 18-II-1894, Lindman 3521 (F). Poconé, 12-II-1990, A. Pott 5502 (CPAP). Ladário, prox. Transpantaneira, Fazenda Jofre, 12-VI-1979, G. Prance \& G. Schaller 26169 (NY).

ECUADOR. NAPO: Añangu. near outlet to Río Napo, 30-VI/9.VII-1982, SEF 10027 (NY, WIS). Jatun Sacha, 3-VIII-1985, D. Neill (MO). Yasuni, 15-I-1994. M. Aulestia \& I. Ima 1568 (MO).

PERU. Cuzco: Convención, Quiteni, 6-I-1976, R. Alfaro 3390 (MO): ibidem, Rosario Mayo, 24-I-1969. R. Alfaro 351 (MO). Hú́Nuco: Tingo Maria, Leonicio Prado, 24-IV-1962, A. Gutiérrez 36 (F, G, NYB, WIS). Tournavista, 28-XII-1962, R. Lao 43 (F, G, NY, WIS). JUnfN: La Merced, 10-24-VIII-1923, J. MacBride 5481 (F). Yaupe, Woytkowski 6403 (K). LoRETo: Iquitos, May- nas, Río Tahuayo, 11-1-1962, V. Arostegui 22 (F, G, WIS). Iquitos-Nauta km 60, J. Ruiz $I I 82$ (K). Mishuyacu, near Iquitos, II/III-1930, G. Klug 949 (F, NY). Nauta, R. Vasquez \& N. Jaramillo 8613 (WIS). Nueva Esperanza, Río Itaya, 17-XII-1976, J. Revilla 36 (F, MO). Puerto Almendras. Río Nanay, 2-XII-1977, A. Gentry \& al. 21043 (F, MO). Quebrada Sasa, 20-VII-1974, R. Kayap 1236 (MO). Requena, Jenaro Herrera, 5-Il2001, T.D. Pennington, A. Daza \& E. López 17121 (K). Río Itaya, above Iquitos, 14-VIII-1972, J. Croat 19167 (MO). MADRE DE Dios: Cusco Amazónica, 6-XI-1991, M. Timaná \& N. Jaramillo 3027 (MO). Manu Parque Nacional, Cocha Cashu Station, $R$. Foster \& B. d'Achille 12068 (K). PAsco: Cerro de Pasco, Palcaju Valley, G. Hartshorn, J. Quijano \& A. Sebastián 2884 (WIS). SAN Martín: Juanjui. Alto Río Huallaga, II-1936, G. Klug 4244 (F, K, MO, S, U). Mariscal Cáceres, NE of Tocache, 6-V-1975, J. Schunke 8402 (F, MO). Nuevo Progresso, Uchiza, 25-VI-1969, J. Schunke 3238 (F, G). UCAYal: Coronel Potillo. Bosque Nacional Von Humboldt. Pucallpa-Tingo María road. 13-XII-1979, N. Begazo 67 (MO). Nueva Requena, J. Diaz 395 (K). Pucallpa, S of Puerto Alegre. 28-VII-1962, M. Mathias \& D. Taylor 6051 (F). Pucallpa-Tingo María, 21-I-2001, T.D. Pennington, A. Díaz \& E. Ceijas I7055 (K).

\section{Ceiba schottii Britten \& Baker f., J. Bot.} 34: 173 (1896)

Ind. loc.: "Hab. Merida, Yucatan, Schott"

Type: Mexico. Yucatán, Mérida, Schott s.n.

(lectotype, here designated, BM!)

Trees c. $8 \mathrm{~m}$ with aculeate trunk and branches, spines on younger branches c. $0.5 \mathrm{~mm}$, black, only slightly curved. Leaves 3-7 foliolate, petiole c. $60 \mathrm{~mm}$ long; leaflets 50-100 $\times$ 19-30 mm, entire, coriaceous, oblanceolate to elliptical, acute, with a small mucron, glabrous, with petiolules $6-10 \mathrm{~mm}$ long. Flowers axillary, borne singly or in fascicles. Pedicels $4 \mathrm{~mm}$ long or less, stout. Calyx $25-40 \times 8$ $10 \mathrm{~mm}$, rather cylindrical (c. $3 \times$ longer than broad), glabrous. Petals $170-190 \times$ c. $15 \mathrm{~mm}$, narrowly oblong, white, densely short hispidhairy externally, scabrous-glabrous internally. Staminal tube $80-100 \mathrm{~mm}$, long and slender, bearing white silky hairs which are prominent in fresh flowers but less evident in dried material, with no appendages and scarcely inflated below division into 5 , c. $70 \mathrm{~mm}$ filaments, which bear versatile, non-anfractuose anthers. Ovary pyriform with slender glabrous, style bearing globose stigma at about same level as anthers. Fruit elongate to ellipsoidal capsule c. $10 \times 5 \mathrm{~cm}$. 
Flowering (June)August-February. Dry woodlands. SW Mexico, Guatemala (fig. 8).

Illustrations. Fig. 9.

A striking species with distinctive entire, mucronate leaflets and cylindrical calyx. Again crepuscular or nocturnal anthesis is likely, and since the petals are held erect, rather than reflexed as in $C$. aesculifolia, perhaps sphingids are the pollinators.

\section{Examined specimens}

Guatemala. Dos Lagunas: Ixcanvio trail, 29-X1960, E. Contreras s.n. (LL, TEX, S). ProGreso: Jalapa, El Rancho, 6-I-1906, W.A. Kellerman 5661 (LL, TEX). 3 km E El Rancho, 2-II-1993, C.E. Hughes 1756 (K, OXF). PETEN: La Libertad, 2-VI-1933, C. Lundell 3569 (S); ibidem, 10-VIII-1934, M. Aguilar 266 (SD). Tikal. 8IX-1960, E. Contreras 1492 (LL).

MEXICO. CAMPECHE: Calakmul, Ejido Narciso Mendoza, $18^{\circ} 14^{\prime} \mathrm{N}, 89^{\circ} 27^{\prime} \mathrm{W}, 25$-VIII-1997, D. Álvarez M. 327 (MBM). Xpujil, 26-II-1973, J.D. Shepherd s.n. (WIS). ChIAPAS: 5 km E Berriozábal, Highway 190, 11 X-1971, D.E. Breedlove 2039 (CAS). Quintana Roo; Carrillo Puerto-Vigía, 12-X-1984, R. Duran \& I. Olmstead s.n. (NY). Othon P. Blanco, $20 \mathrm{~km}$ W Majhual, 29VIII-1983, R. Durán \& I. Olmstead 444 (NY). 3 km N Xelah, 11-X-1980, O. Téllez \& L Rico 3545 (NY). YU-
CATÁN: Chichansanal (?), G.F. Gaumer 1921 (F, NY). Izamal, G.F. Gaumer 694 (CAS, G, S, WIS). Piste, VVIII-1938, C.L. \& A.A. Lundell 7539 (LL, DS). San Pedro, VI-1916, G.F. Gaumer 23368 (G, NY).

16. Ceiba aesculifolia (Kunth) Britten \& Baker. J. Bot. 34: 175 (1896)

Bombax aesculifolium Kunth in Humb., Bonpl. \& Kunth, Nov. Gen. Sp. 5: 298 (1822)

Eriodendron aesculifolium (Kunth) DC., Prodr.: 479 (1824)

Bombax axillare Moç. \& Sessé ex DC., Prodr.: 479 (1824), nom. nud.

Ind. loc.: "Crescit prope Campeche, ad litus Nova Hispaniae"

Type: Mexico. Campeche, Humboldt \& Bonpland s.n. (lectotype, here designated, P!)

Tree 8-10 m with aculeate trunk. Leaves 57 foliolate, petiole $20-120 \mathrm{~mm}$ long; leaflets $30-100 \times 18-40 \mathrm{~mm}$, elliptical to narrowly oblanceolate or obovate, apex acuminate, margin denticulate to serrate, glabrescent or uniformly finely hairy with stellate and simple hairs, or hairs restricted to nerves, petiolule 3-12 mm long. Flowers usually borne

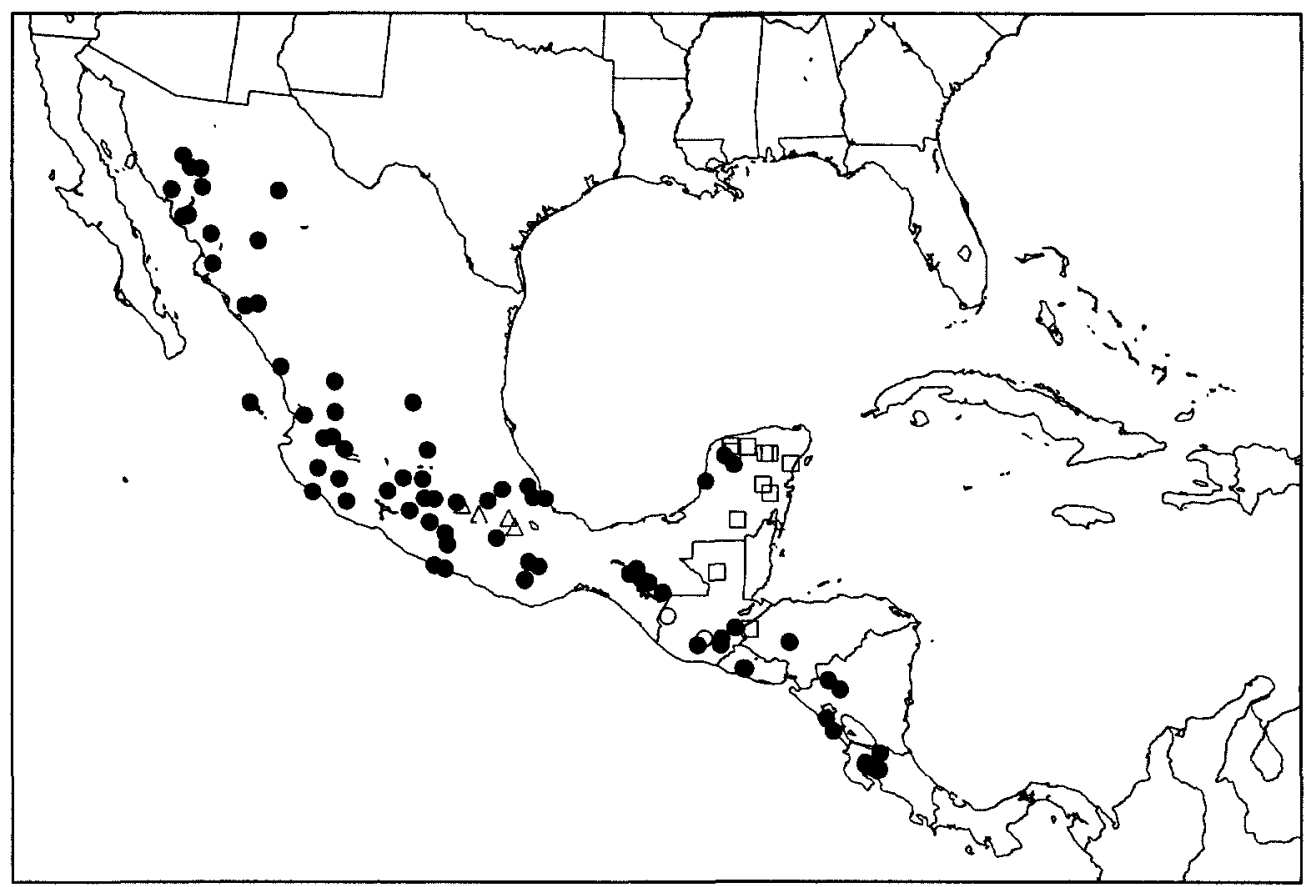

Fig. 8.-Distribution map of Ceiba aesculifolia, $\square$ C. schotrii and $\triangle C$. soluta. 
singly, petals markedly reflexed. Pedicels 10 $20 \mathrm{~mm}$ long, stout. Calyx 17-45 $\times 15-30 \mathrm{~mm}$, funnelform to broadly campanulate, $4-5$ lobed, glabrous or with fine hairs. Petals $100-$ $130 \times 14-25 \mathrm{~mm}$, narrowly oblong, obovate or somewhat acute, sericeous to coarsely villous externally, glabrous within, white tinged green in colour but hairs may have a tan colour. Lower staminal tube $15-25 \mathrm{~mm}$, hairy, with 5 densely hairy scale-like appendages, giving rise to 5 free filaments which stand erect between the 5 reflexed petals, anthers markedly anfractuose. Fruit ellipsoidal to pyriform capsule, c. $15 \times 8 \mathrm{~cm}$.

Flowering March to July (see comments below). Dry hillsides, semi-deciduous woodland. Northern Mexico southwards to Central America (fig. 8).

As recognized here, $C$. aesculifolia is a very variable species which is widely distributed from Campeche to Sonora in Mexico, and Central America. There is wide variation in e.g. calyx size, length of the stamens in comparison with the petals, pubescence, and even flowering time (most examples seen flower between March to July but some August to January flowering specimens have been seen) and one would anticipate that some of the numerous species names which have been published for this group (see synonymy below) may comprise valid taxa. There are certainly striking differences in petal size and shape (particularly whether the apex is rounded or acute), and degree of exsertion of the stamens, and also pubescence (used to delimit $C$. tomentosa but note that e.g. Hinton 13878 has young leaves with simple and stellate hairs, but older leaves only with sparse hairs on the midrib). However, we have been unable to correlate any character differences consistently with distribution patterns.

Again the fact that $C$. aesculifolia usually flowers in a leafless state, with nocturnal anthesis (Bullock 1583 comments anthesis at $20.15 \mathrm{~h}$ ) and bat pollination (BAKER \& al., 1971), means that most flowers are collected the following day as they are wilting. As a consequence, the quality of some of the herbarium material available is of limited value. This is a group where field studies, or the collection of carefully annotated leaf and flowering specimens, with photographs, may yet reveal variation within $C$. aesculifolia s.l. which merits recognition at species level.

1. Leaflets $30-100 \times 18-40 \mathrm{~mm}$, acuminate a. subsp. aesculifolia

- Leaflets 20-40 × 13-18 mm, obscurely mucronate b. subsp. parvifolia

\section{a. subsp. aesculifolia}

Eriodendron acuminatum S. Watson, Proc. Amer. Acad. Arts 21: 418 (1886); Ceiba acuminata (S. Watson) Rose, Contr. U.S. Natl. Herb. 8: 320 (1905)

Ind. loc.: "Hacienda San Miguel (F). Perhaps the same that was collected by Moçino \& Sessé (Icon t. 94), referred by De Candolle to Eriodendron aesculifolium a species from the coast of Campeche"

Type: Mexico. Chihuaha, Hacienda San Miguel, 1885, E. Palmer s.n. (lectotype, here designated, US!)

Eriodendron tomentosum B.L. Rob., Proc. Amer. Acad. Arts 29: 314 (1894); Ceiba tomentosa (B.L. Rob.) Britten \& Baker f., J. Bot. 34: 175 (1896)

Ind. loc.: "Collected on a barranca near Guadalajara. June 1892 (no. 5300)"

Type: Mexico. Jalisco, near Guadalajara, VI1892 , Pringle 5300 (no original material located)

Ceiba grandiflora Rose, Contr. U.S. Natl. Herb. 1: 308 (1895); Eriodendron grandiflorum (Rose) Conz., Gen. Veg. Mexic.: 125 (1903)

Ind. loc.: "In rich valleys and in the mountains about Manzanillo, December 1-31, 1890, Rose 1050"

Type: Mexico. Colima. Around Manzanillo, 1/31-XII-1890, Palmer 1050 (lectotype, here designated, US-digital image!)

Ceiba pallida Rose, Contr. U.S. Natl. Herb. 8: 320 (1905)

Ind. loc.: "Collected by J.N. Rose and Walter Hough near Cuernavaca, May 27 to 30, 1899 (no. 4337 type) and by C.G. Pringle from the same tree, May 311899 (no. 8212)" 


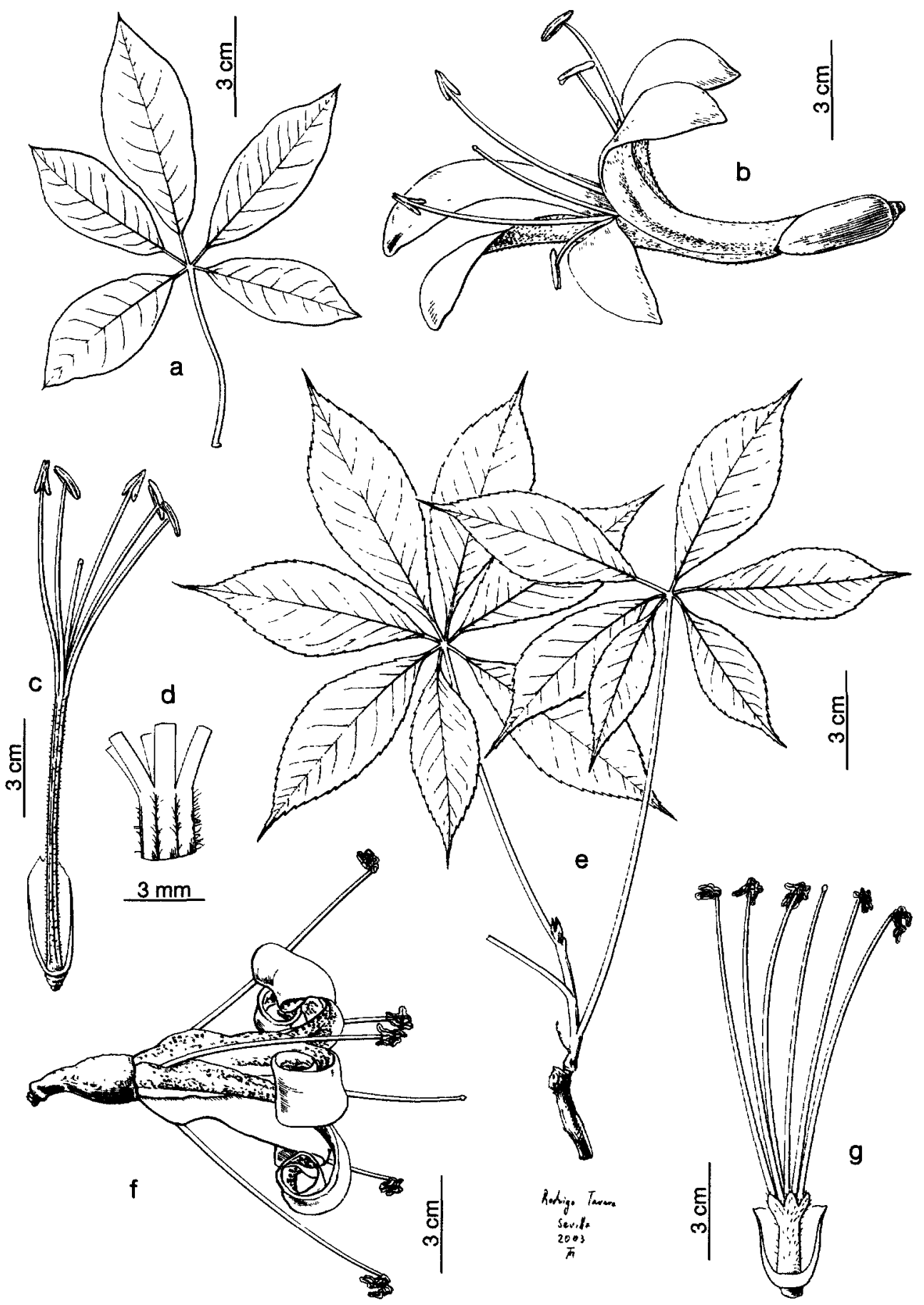

Fig. 9.-Ceiba schotii (Gaumer, Plantae Yucatanae 694, E): a) leaf; b) flower at anthesis; c) androecium; d) detail of terminal part of staminal tube. C. aesculifolia (Pringle. Plantae Mexicanae s.n., E): e) branch with leaves; f) flower at anthesis: $\mathrm{g}$ ) androecium. 
Type: Mexico. Morelos, Near Cuernavaca, 27/30-V-1899, Rose \& Hough 4337 (holotype, US!)

Leaflets 30-100 $\times 18-40 \mathrm{~mm}$, acuminate elliptical to narrowly oblanceolate, with denticulate to serrate margin and acute apex, usually glabrous or with sparse simple or stellate hairs.

Flowering March to July [but occasional specimens from diverse localities, e.g. Puebla (Dunn \& Dunn 18741), Michoacan (Iltis \& Doebley 45) flowering September to January). Dry valleys and hillsides. Widespread in Mexico and extending southwards to Belize and Guatemala.

\section{Illustrations. Fig. 9.}

Although Pringle 5300, the type of E. tomentosum, has not been located, it is likely to be similar to other collections from this locality, e.g. Pringle 4733 and Pringle 9685 , both of which we refer to $C$. aesculifolia. Eriodendron acuminatum was described from a fruiting specimen, and flowering characters were derived from Sessé \& Moçiño, icon 94 (cf. WHITE \& al., 1998). RoSE (1905), on making the transfer as Ceiba acuminata commented: "Type locality: Hacienda San Miguel, Chihuahua, collected by Dr. E. Palmer. This species known only from the type collection and has never been collected in flower. It must be near $C$. tomentosum and with this material in hand it is difficult to separate them. The flowers may well show good specific differences".

ROSE (1905) also noted that Pringle 8212 was collected from the same tree as Rose \& Hough 4337, the type of Ceiba pallida.

\section{Examined specimens}

Bellze. Comayagua: Agua Salada, 18-IV-1951, P.H. Allen 6228 (CAS, F).

Costa Rica. Finca La Pacífica, 2 miles $\mathrm{N}$ of Las Cañas, 8-VI-1971, A. Gentry 861 (LL). Puntarenas: Near junction Rio Guacimal and R. San Luis, 11-XII1989, D. \& H.H. Iltis \& W. Haber 30342 (WIS).

EL Salvador. Hacienda El Ángel, X-1923, S. Calderón $1888(\mathrm{NY})$.

Guatemala. Jalapa: El Rancho, 5-I-1908, W.A. Kellerman 4862 (NY). Zacapa, 22-I-1905, B.L Robinson $163(\mathrm{NY})$.
Mexico. Chiapas: Berriozábal, 11-X-1971, D.E. Breedlove 20392 (DS). Highway 190, Terán, 4-I-1972, D.E. Breedlove \& E. McClintock 23455 (DS). $3 \mathrm{~km} \mathrm{~N}$ Ocozocoautla de Espinosa, 19-XI-1972, D.E. Breedlove \& R.L Dressler 29686 (DS). $6 \mathrm{~km}$ SE Acala-Venustiano Carranza. 26-II-1966, $R$. Laughlin 328 (DS). CHIHUAHUA: Barranco de Cobre, 5-IV-1940, I. Knochbloch 7032 (US). Santa Rosa, 30-V-1960, T.R. Pennington 266 (TEX). Colima: Manzanillo, 26-XI-1925, $R$. Ferris 6087 (DS). DURANGO: $8 \mathrm{~km}$ W Remedios, 15-IV-1943, H.S. Gentry 6821 (NY). GUERRERO: Alcapuco-San Marcus, J.S. Miller \& P. Tenorio 546 (WIS). 2 mis E of Acapulco. 9-I-1944, F.A. Barkley 14088 (TEX). 48 km N Chilpancingo, D.J. Macqueen \& al. 429 (K, OXF). JALISCO: Barranco de Guadalajara, 18-VII-1902, C.G. Pringle 9685 (LL, TEX). Bolaños, 10-19-IX-1897, J.N. Rose 2934 (US). Etzatlán, 2-X-1903, J.W. Rose \& J.H. Painter 7539 (NY), Guadalajara, 9-VII-1899, J.N. Rose \& W. Hough 4812 (NY, US); ibidem, 4-VIII-1990. M. Cázaro, J.J. Guerrero \& S. Carvajal 6273 (WIS). Guadalajara-Bolaños, 22-IX-1897, J.N. Rose 3096 (US). La Huerta, S.H. Bullock (K). Near Guadalajara, 3-V/10-VII-1894, C.G. Pringle 4733 (E, G, NYB, W). Near Tequila, 5-VI-/VII-1899, J.N. Rose \& W. Hough 4742 (US). 8 km N El Grullo, 16-VIII-1990. L. Hernández \& A. Vázquez 50 (WIS). $10 \mathrm{~km}$ W Zamora. F.A. Barkley, J. Paxson \& C. Rowell 7668 (TEX). MICHOACÁN: Coalcoman de Matamoros, 7-IV-1939. G. Hinton 13878 (LL). Morelia, 18-XI-1910, G. Arsène 5273 (G). Tecpan, 11-I-1899, E. Langlassé 739 bis (P). $2 \mathrm{ml} \mathrm{N}$ Río Tuxan, 13-VII-1940, C.L. Hitchcock \& L.R. Stanford 7137 (DS). $10 \mathrm{~km} \mathrm{~W}$ of Tuxpan, 15-IX-1977, H.H. Iltis \& J.F. Doebley 45 (WIS). MoRelos: Cuenevaca, 31-V1899. C.G. Pringle $82 / 2$ (E, NY, P, W). NAYARIT: $4 \mathrm{ml}$ San Blas-Tepic, 15-X-1925, R.S. Ferris 5535 (DS). Near Ixtlán, 23-IX-1926, Y. Mexia 728 (CAS, DS, G, NY). OAXACA: Hacienda Guadalupe, 11-III-1937. C. Conazati 5252 (NY). $20 \mathrm{~km}$ NW of Miahuatlan, S.L. Solheim \& B.F. Berg 1185 (WIS). PUEBLA: Huajuapan de León to Izúcar de Matamoros, 2-1I-1970, C.\& W.R. Anderson 5652 (DS). Near Querétaro, 20/23-VIIl-1906, J.N. \& J.S. Rose 11158 (NY). Tlacuilotepec, VII-1909, C.A. Purpus 4009 (NY). 2 km E of Zapotitlán, A. Salinas \& al. F3749 (WIS). QuerÉTARo: El Batán, 23-VI-1978, Argüelles 1093 (CAS). SinaloA: Culiacán, 8-XI-1990, F.S. Brandegee s.n. (DS, US). La Calera, San Ignacio, 31-V-1919. M. Narvael Montes \& A.E. Salazar 854 (US). Labradas, 19-IX-1925, R.S. Ferris \& Y. Mexia 5172 (CAS, DS). Near Coloma, Sierra Madre, 16-VII-1897, J.N. Rose 1705 (NY). Quebrado de Mansana, 10/14-IX-1941, H.S. Gentry 6578 (DS, NY, US). Rosario, 14-IV-1910, J.N. Rose, P.C. Standley \& P.G. Russell 14541 (US). San Blas, 29III-1910, J.N. Rose, P.C. Standley \& P.G. Russell 13629 (US). San Ignacio, 31-V-1919, A.E. Salazar 854 (US). Tepic, J.G. Ortega 4908 (K. NY, US). SONORA: Los Durazillos, 18-V-1892, T.S. Brandegee s.n. (DS). Near Navajoa, 1933, J. Manson s.n. (DS). Onavas, 14-VII1969, C.W. Pennington 322 (TEX). San Bernardo, 27-VI1935, H.S. Gentry 1451 (US, WIS). $9 \mathrm{mls} \mathrm{N}$ of Ures, 20 IX-1934, l. Wiggins 7341 (DS). $10 \mathrm{mls}$ NE of MátapeBatuc, 9-IX-1941, I. Wiggins \& R.C. Rollins 449 (DS, NY, US). $10 \mathrm{mls}$ N of Alamos, 19-VI-1964. J. Henrickson I600 (E). 19 miles SE Alamos, 31-VII-1969, J.R. Mason, 
C.T. Jones \& P. Shaw 2929 (CAS). $10 \mathrm{mls}$ E of Moctezuma, 3-VI-1971, H.S. Gentry \& Argüelles 22934 (US). Tres Marias ISLANDS: Maria Madre, 25-X-1925, R.S. Ferris 6260 (DS).VERACRUz: Pachuchilla, 24-IV-1971, F. Ventura 3493 (DS). Remulatero, IV-1922. C.A. Purpus 8770 (NY). Rinconada, 1894, C.L. Smith 1567 (NYB). $6 \mathrm{~km}$ ESE of San Antonio Paso del Toro, 14-I-1984, $M$. Nee \& K. Taylor 28815 (F, K). YUCATÁN: Suitun, V-1916, G.F. Gaumer 23312 (G). S of Kankabronot, V-1917, G.F. Gaumer 23879 (G). ZACATECAS: San Juan CapistranoHuejuquilla, 23-VIII-1897, J.N. Rose 2494 (NY).

b. subsp. parvifolia (Rose) P.E. Gibbs \& Semir. comb. \& stat. nov.

Ceiba parvifolia Rose, Contr. U.S. Natl. Herb. 8: 320 (1905)

Ind. loc.: "Collected by the writer on the dry hills near the little town of Matamoros, Puebla"

Type: Mexico. Puebla, Matamoros, 26-VI1899, Rose \& W. Hough, 4701 (lectotype, here designated, US!) A sterile specimen.

Leaves 5-7 foliolate. Petioles 25-35 mm, petiolules, leaflets $20-40 \times 13-18 \mathrm{~mm}$, broadly elliptical to obovate, apex obscurely mucronate, with sparse stellate hairs to glabrescent.

Flowering December-January? Dry valleys. Mexico, apparently restricted to states of Morelos, Puebla and Oaxaca within the general distribution of the larger leaved form.

Many specimens of $C$. aesculifolia are leafless, and it is not possible to distinguish beween the two subspecies on flower alone. The following specimens of $C$. parvifolia all bear leaves.

\section{Examined specimens}

MeXico. Morelos: Near Yautepec, 27-VIII-1903, J.W. Rose \& J. Painter 6564 (US). OAXACA: Lower Tehuacan Valley-2 km S of San Juan de los Cues (18 $03^{\prime}$ N. 97 $94^{\circ}$ 'W), 17-XI-1993, C.E. Hughes 1806 (E, FHO, K, MEXU, NY). Tomellin Cañón. 23-VI-1899, J.W. Rose \& W. Hough 4670 (US). 3 km ENE of Teotilán, 16-IX-1977, $M$. Sousa 8077 (CAS, SD). PuEbla: Near Chila de las Flores, $42 \mathrm{~km}$ WNW Huajapan $\left(17^{\circ} 57^{\prime} \mathrm{N}\right.$, 97'52' W), 19-XI-1993, C.E. Hughes 1814 (E, F, K). Near Coxcatlan, VII-1961, C.E. Smith. F. Peterseu \& N. Tejeda 3639 (G). Near Tehuacán, IX-1906, J.N. \& J.S. Rose, 11407 (US). $6 \mathrm{~km}$ SSW of Axusco, 4-X-1986, A. Salinas \& P. Solis F3582 (WIS).

The following specimens have flowers and no leaves, but since they are from Oaxaca and Puebla, and in flower in December to January, they may be examples of subsp. parvifolia.
OAXACA: Between Oaxaca and Tehuantepec, 20-XII1875, A.A. Reznicek \& D.R. Gregory 307 (NY). Near Pueblo Nuevo, 3-I-1945, E.J. Alexander 245 (NY). 49 miles SE of Oaxaca along road to Tehuantepec, 23-I1964, R.J. Barr 64.63 \& C.T. Mason 2367 (DS). $4 \mathrm{~km}$ $\mathrm{N}$ of Tecomavaca, $17^{\circ} 43^{\prime} \mathrm{N}, 97^{\circ} 01^{\prime} \mathrm{W}, 5-\mathrm{XII}-1987$, A. Campos 682 (MBM). PuEbla: $5 \mathrm{ml}$ W of Matamoros, 3-I-1972, D. \& D.B. Dunn 18741 (NY).

\section{Ceiba soluta (Donn. Sm.) Ravenna, Oni-} ra 3: 47 (1998)

Chorisia soluta Donn. Sm., Bot. Gaz. 16: 1 (1891)

Ind. loc.: "Shores of Lake Amatitlan, Dept. Amatitlan, alt. 3,900 feet, Feb., 1890, J.D.S."

Type: Guatemala. Amatitlan, shores of Lake Amatitlan. II-1890, Donnell Smith s.n. (lectotype, here designated, BM!; isolectotype, K!)

Tall trees with aculeate trunk and flattish, spreading crown. Leaves described as digitate, but not seen by us. Pedicel very stout, $10 \mathrm{~mm}$ long. Calyx also very robust, c. $30 \times$ $30 \mathrm{~mm}$, orange-brown hairy without, very densely villous pubescent within. Petals c. $140 \times 35 \mathrm{~mm}$, spathulate, with a white inner surface, and golden brown hairy externally, reflexed and curling back. Staminal tube c. $20 \mathrm{~mm}$, with a corona of five, bifid. densely hairy scales, with (10)15 slender, free filaments, c. $105 \mathrm{~mm}$, each bearing a c. $7 \mathrm{~mm}$ anfractuose monthecate anther. Ovary c. $8 \mathrm{~mm}$, pyriform, with a long, slender style which exceeds the level of the anthers by $10 \mathrm{~mm}$ or so, but the form of the stigma unknown. Fruit not seen.

Flowering February. Dry woodland. Apparently endemic to Guatemala (fig. 8).

Until the recent collection by $H$ ughes \& al. 1690 , this remarkable species was only known from the type collection which consists of fallen flowers. The description above is derived partly from that of Donnell Smith, but floral details are mostly from the Hughes specimen. These latter flowers, although evidently larger than the Donnell Smith collection, agree in most respects with type description except in one intriguing detail: the original description for this species refers to 
10-12 filiform staminal filaments, and Donnell Smith further emphasises this point in his additional comments, noting that freshly fallen flowers were the only ones accessible, and that the staminal column "partite to the annulus into double the number of branches is exceptional for the genus". The type specimen at $\mathrm{BM}$ and a duplicate collection at $\mathrm{K}$ both have floral fragments with 10 staminal filaments, whereas both flowers of the Hughes \& al. 1690 collection seen by us have 15 filaments.

Given the close resemblance of the type specimens of Chorisia soluta to the very variable $C$. aesculifolia, which also extends to Guatemala, and given the fact that $C$. aesculifolia also has some very large flowered specimens with a robust calyx, we were initially inclined to treat the type specimen of $C$. soluta simply as an odd double-filamented variant of C. aesculifolia, especially since it was based on a single tree. This was also the interpretation of STANDLEY \& STEYERMARK (1949) who treated Chorisia soluta as a synonym of Ceiba aesculifolia. However, the Hughes \& al. 1690 collection shows that other specimens occur with a similarly multi-filamented androecium comparable to the Donnell-Smith collection, although the number of free filaments seems to rather variable. In these circumstances, despite its evident affinity with $C$. aesculifolia, we maintain Ceiba soluta as a species.

\section{Examined specimens}

Guatemala. Huehuetenango: Close to track running WSW from Colotenango and Ixtahuacan towards the small village of San Miguel, $15^{\circ} 24^{\prime} \mathrm{N}, 91^{\circ} 50^{\circ} \mathrm{W}$, 28-II-1992, C. Hughes 1690, S. Harris \& R. Atkinson (E, FHO, K).

\section{EXCLUDED OR DOUBTFUL NAMES}

Ceiba sect. Eriodendron K. Schum. in Engl. \& Prantl (eds.), Nat. Pflanzenfam. 3(6): 63 (1890). Type: Ceiba rivieri (Decne.) K. Schum.

Ceiba allenii Woodson, Ann. Missouri Bot. Gard. 29: 359 (1942) Spirotheca allenii (Woodson) Cuatrec., Revista Acad. Colomb. Ci. Exact. 9: 167 (1954)
Ceiba caribaea (DC.) A. Chev., Rev. Int. Bot. Appl. Agric. Trop. 17: 266 (1937) [Eriodendron anfractuosum var. cari- : baeum DC.] = Ceiba pentandra according to BAKHUIZEN VAN DEN BRINK (1924) and BAKER (1965)

Ceiba casearia Medik., Malvenfam.: 16 $(1787)=$ Eriodendron orientale Kurz, which according to BAKER (1965) is Ceiba pentandra

Ceiba guineensis (Thonn.) A. Chev., Rev. Int. Bot. Appl. Agric. Trop. 17: 261 (1937) [Bombax guineense Thonn.] is Ceiba pentandra according ROBYNS (1963) and BAKER (1965)

Ceiba jasminiflora (A. St. Hil.) K. Schum. in Engl. \& Prantl (eds.), Nat. Pflanzenfam. 3(6): 63 (1890). Presumably an orthographic error for C. jasminodora (A. St. Hil.) K. Schum.

Ceiba microphylla K. Schum. in Mart. (ed.), Fl. Bras. 12(3): 213 (1886). Based on a flowerless specimen. Leaf morphology similar to Spirotheca rivieri (K. Schum.) Ulbr., but the reference to "yellow kapok" may indicate Eriotheca candolleana (K. Schum.) Robyns

Ceiba mythica Ravenna, Onira 3(15): 47 (1998)

Ind. loc.: "On hilly areas of the Piura department, Peru, e.g. on the way to Huancabamba $240-2600 \mathrm{~m}$ "

Type: Peru. Piura, in montanibus ad viam Huancabamba, III-1979, Ravenna 2507 (holotype, herb. Ravenna)

Described briefly and rather cryptically from a single specimen as: "Arbor 6-10 m, saepe varie contorta. Truncus distincte ventricosus, inermis, olivaceus vel opace viridis, 1-1.5 m crassus. Rami ample patentes. aculeis conicis $10-20 \mathrm{~mm}$ longis, armati. Flores albi. Capsulae et semina ut in C. speciosa". RAvENNA (1998) further commented: "Trees of this species display rather strange forms, resembling fantastic figures. The short description was taken from the writer's field notes. Poorness of the type specimen do not help as to its completion. However, the tree habit is so unusual that the species cannot be mistaken for any other". 
There is obviously insufficient data here to determine whether this description is indeed a new taxon of Ceiba. Some comment as to whether the staminal tube is entire or with five free filaments would have been helpful. We have not seen the apparently fragmentary type specimen. Pending further collections, we assume, from the locality and description of white flowers, that this material represents rather malformed trees of $C$. insignis, which also occurs in Piura.

Ceiba phaeosantha K. Schum. in Mart. (ed.), Fl. Bras. 12(3): 214 (1886). Schumann commented "species mihi non visi" and based this species on Eriodendron phaeosantha Decne., J. Soc. Hort. Paris 4: 90-94 (1870), described from a tree cultivated in Algeria. Description indicates this may be Ceiba samauma

Ceiba rivieri (Decne.) K. Schum. in Mart. (ed.), Fl. Bras. 12(3): 212 (1886) [Eriodendron rivieri Decne., Fl. Serres Jard. Eur. ser. 2, 12: 167 (1877)]. Based on a tree cultivated in Algeria [Spirotheca rivieri (Decne.) Ulbr., Notizbl. Königl. Bot. Gart. Berlin 6: 162 (1914)]

Ceiba rosea (Seem.) K. Schum. in Engl. \& Prantl Nat. Pflanzenfam. 3(6): 63 (1890) [Chorisia rosea Seem., Bot. Voy. Herald: 84 (1853)]. To be transferred to the genus Spirotheca.

Ceiba salmonea (Ulbr.) Bakh., Bull. Jard. Bot. Buitenzorg ser. 3, 6: 198 (1924) [Spirotheca salmonea Ulbr., Notizbl. Bot. Gart. Berlin 6: 160 (1914)]

Ceiba thonningii A. Chev., Rev. Int. Bot. Appl. Agric. Trop. 17: $249(1937)=$ Ceiba pentandra according to BAKER (1965)

Chorisia josephinae Bertoni, Anales Ci. Parag. ser. 2, 2: 139 (1918) According to BERNARDI (1984) $=$ Ceiba chodatii

\section{ACKNOWLEDGEMENTS}

We thank the Directors and Curators who have loaned specimens or permitted visits to their herbaria. The first author is especially grateful to the curators of F, MO and NY for showing endless patience and courtesy with loans retained over far too many years. Our late dear friend and colleague
Neusa Diniz da Cruz was involved in early cytological and reproductive biology studies with ChorisiaCeiba species. Neusa always avoided the taxonomic part, but she understood the taxonomic process and her common sense opinions from the sidelines were much missed as this work progressed. The late $\mathrm{Al}$ Gentry provided photographs and comments in letters which gave us important insights into $C$. insignis, $C$. lupuna and $C$. boliviana. Julie Dutilh was always ready to provide the second author with field transport. or to include the search for ceibas in her own field expeditions. Also to Dr Piet Stoffelen for checking for the presence of a Von Wied collection of $C$. ventricosa at BR. We thank Dr Salvador Talavera for a critical reading of the draft mss., and also the editor and anonymous referees for numerous textual improvements, and Rodrigo Tavera for preparation of the illustrations. Finally, the first author is indebted to Kirsten Llamas, who by repeatedly sending him photos of ceibas cultivated in Florida to identify, made him feel that his knowledge of these taxa was actually of some use, and stimulated the final push to complete this revision. Also to Dick Brummitt and Gwilym Lewis at RBG Kew, for patiently supplying bibliographic information, and to the Brazilian Conselho Nacional de Desenvolvimento Científico e Tecnológico for the award of a visiting research fellowship which allowed final stages of this study to be completed.

\section{REFERENCES}

ADAMS, C.D. (1972). Flowering plants of Jamaica. University of the West Indies, Mona, Jamaica.

BAKER, H.G. (1965). The evolution of the cultivated kapok tree: a probable West African product. $l n$ : D. Broken-Sha (ed.), Ecology and economic development in tropical Africa. Institute of International Studies, Univ. California, Berkeley, pp. 185-216.

BAKER. H.G. \& B.J. HARRIS (1964). Bat pollination of the kapok tree, Ceiba pentandra (L.) Gaertn. (Bombacaceae). J. W. African Sci. Assoc. 5: 1-9.

BAKER, H.G. \& I. BAKER (1968). Chromosome numbers in the Bombaceae. Bot. Gaz. 129: 294-296.

BakeR, H.G., R.W. Cruden \& I. Baker (1971). Minor parasitism in pollination biology and its community function: the case of Ceiba acuminata. Bioscience 21: 1127-1129.

BaKhuizen VAN DEN BRink, R.C.B. (1924). Revisio Bombacacearum. Bull. Jard. Bot. Buitenzorg ser. 3, 6: $161-240$.

BernaRdini, L. (1984). Contribución a la dendrología paraguayana. Boissiera 35: 30-50.

BritTen, J. \& E.G. BAKER (1896). Notes on Ceiba. J. Bot. 34: 173-176.

BurdeT, H.M. (1976). Cartulae ad botanicorum graphicum VIII. Candollea 31: 127-158. 
Dawson, G. (1944). Las especies del género "Chorisia" cultivadas para adorno en la República Argentina. Revista Argent. Agron. 11: 1-10.

De Candolle, A.P. (1824). Bombacaceae in Prodromus systematis naturalis regni vegetabilis... 1: 475-480. Paris.

Digilio, A.P.L. \& P.R. Legname (1906). Los árboles indígenas de la provincia de Tucumán. Opera Lilloana 15: 1-107.

DRUCE, G. (1913). The abridgement of Miller's Gardners Dictionary of 1754. Bot. Exch. Club Soc. Brit. Isles 3: 426-436.

GibBs, P.E. \& M.B. Bianchi (1993). Post-pollination events in species of Chorisa (Bombacaceae) and Tabebuia (Bignoniaceae) with late-acting self-incompatibility. Bot. Acta 106: 64-71.

GiBBS, P.E. \& M.B. BIANCHI (1999). Does Late-acting Self-incompatibility (LSI) Show Family Clustering? Two More Species of Bignoniaceae with LSI: Dolichandra cynanchoides and Tabebuia nodosa. Ann. Bot. (London) 84: 449-457.

GiBBS, P.E., J. SEMIR \& N.D. DA CRUZ (1988). A proposal to unite the genera Chorisia Knuth with Ceiba Miller (Bombacaceae). Notes Roy. Bot. Gard. Edinburgh 45: 125-136.

GlazioU, A.F. (1913). Plantae Brasiliae centralis a Glaziou lectae. Bull. Soc. Bot. France, Mém. 3: 1-112.

Gribel, R. \& P.E. GiBBs (2002). High outbreeding as a consequence of selfed ovule mortality and single vector bat pollination in the Amazonian tree Pseudobombax munguba (Bombacaceae). Int. J. Pl. Sci.163: 1035-1043.

GriBEL, R., P.E. GiBbs \& A.L. QueIroz (1999). Flowering phenology and pollination biology of Ceiba pentandra (Bombacaceae) in Central Amazonia. J. Trop. Ecol. 15: 247-263.

HeYwood, V.H. (1963). The species aggregate in theory and practice. Regnum Veg. 27: 26-37.

Kunth, C. (1822). Chorisia. In: F. Humboldt, A. Bonpland \& C. Kunth (eds.), Nova genera et species plantarum 5: 295-298. Paris.

LORENZI. H. (1992). Árvores Brasileiras. Editora Plantarum Ltda., Nova Odessa.

LORENZI, H. (1998). Árwores Brasileiras 2. Instituto Plantarum de Estudos da Flora Ltda., Nova Odessa.

MACBRIdE, J.F. (1956). Flora of Peru. Field Mus. Nat. Hist., Bot. Ser. 13, 3A(2): 601-605 [Ceiba].

MARTIUS, C.F. \& J.G. ZuCCARINI (1823-26). Nova genera et species plantarum... vol. 1. Typis Lindaueri, Monachii.

Miller, P.H. (1754). The gardeners dictionary... Abridged... ed. 4. London.

NeEs, C.G. \& C.F. MarTius (1823). Goethea novum plantarum genus... Nova Acta Phys.-Med. Acad. Caes, Leop.-Carol. Nat. Cur. 11:89-102.

Nicolson, D.H. (1979). Nomenclature of Bombax, Ceiba (Bombacaceae) and Cochlospermum (Cochlospermaceae) and their type species. Taxon 28: 367-373.

Pennington, R.T., D.E. Prado \& C.A. Pendry (2000). Neotropical seasonally dry forests and Quaternary vegetation changes. J. Biogeogr. 27: 261-273.

PLUMIER, C. (1703). Nova plantarum americanarum genera... Paris.
Prado, D.E. \& P.E. GibBs (1993). Patterns of species distributions in the dry seasonal forests of South America. Ann. Missouri Bot. Gard. 80: 902-927.

Pringle, C.G. (1894). Notes on Mexican travel VII. Gard. \& Forest 7: 153-154.

RAVENNA, P. (1998). On the identity, validity, and actual placement in Ceiba of several Chorisia species (Bombacaceae), and description of two new South American species. Onira 3(15): 42-51.

Robyns, A. (1963). Essai de Monographie du genre Bombax s.l. (Bombacaeae). Bull. Jard. Bot. Etat. 33: 1-316.

ROBYNS, A. (1967). Bombaceae neotropicae novae 1. New species of Chorisia and Quararibea. Ann. Missouri Bot. Gard. 54: 184-187.

Rose, J.N. (1905). Studies of Mexican and Central American Plants no. 4. Contr. U.S. Natl. Herb. 8: 281-339.

SAINT HilaIRE, A. (1824-33). Flora brasiliae meridionalis... Paris.

SANDWITH, N.Y. (1968). Humboldt and Bonpland's itinerary in Ecuador and Peru. In: W.T. Stearn (ed.), Humboldt, Bonpland, Kunth and Tropical Botany: 87-89. J. Cramer, Lehre.

SANTOS, E. (1964). Nova combinação no gênero Chorisia HBK. Sellowia 16: 163-172.

SANTOS, E. (1967). Chorisia. In: R. Reitz (ed.), Flora ilustrada catarinense, Bombacáceas. Blumenau. Brazil.

SANTOS, E. (1969). Flora ecológica de restingas do sudeste do Brasil. VIII. Bombacaceae. Museu Nacional. Rio de Janeiro.

SCHUMANN, K.M. (1886). Bombacaceae. In: C.F. Martius (ed.), Flora Brasilinesis 12(3): 201-250. München, Wien, Leipzig.

SChUMANN, K.M. (1890). Bombacaceae. In: A. Engler \& K. Prantl (eds.), Die Natürlichen Pflanzenfamilien... 3(6): 53-68. Leipzig.

SeaveY, S.R. \& K.S. BaWA (1986). Late-acting selfincompatibility. Bot. Rev. 52: 196-217.

StANDLEy, P.C. \& J.A. Steyermark (1949). Flora of Guatemala. Fieldiana, Bot. 24(6): 389-393 [Ceiba].

TAdDEI, V.A. (1977). Phyllostomidae da região norteoccidental do estado de São Paulo. Doctoral thesis, Universidade Estadual de São José do Rio Preto.

UlbRICH, O.E. (1914). Spirotheca Ulbr. Notizbl. Königl. Bot. Gart. Berlin 6: 159-162.

VAN HEEL, W.A. (1966). Morphology of the androecium in Malvales. Blumea 13(2): 177-394.

White, J.J. R. MCVAugh \& R.W. Kiger (1998). The Torner collection of Sessé \& Moçiño biological illustrations. CD-ROM published by the Carnegie Mellon CD Press.

\section{COLLECTION INDEX}

(The species is indicated by a number in parenthesis corresponding to the number in the revision)

Acosta Solis 7976 (12); Aguilar 266 (15); Alexander 245 (16b?); Alfaro 351 (14), 3390 (14); Allen 6228 (16a), 7203 (13); Almeida 58 (7); Alston 7964 (13); Álvarez M. 
327 (15); Amaral \& al. 920 (3); Anderson \& al. 8899 (11); Anderson 5652 (16a); Anderson 8899 (11); Andrade-Lima \& al. P26 (9), 309 (9), 5436 (10), 55-2093 (9); Araujo 3758 (10); Arbo \& al. 4363 (11); Argüelles 1093 (16a); Amaldo 1966 (13); Arostegui 22 (14); Arsène 5273 (16a); Asplund 1655 (13), 16562 (12), 16607 (12), 18089 (1), 20523 (13); Aulestia 367 (2); Aulestia \& al. 1568 (14).

Badcock 630 (8); Balls 5923 (6); Bang 1154 (8), 1175 (3); Barkley 14088 (16a); Barr 6463 (16b?); Barr \& al. 2367 (16a); Barros 1084 (11); Bartlett 12432 (13); Beck 1771 (8), 2257 (8); Begazo 64 (14); Belém \& al. 868 (5): Belém \& al. 3397 (10); Belém 3792 (10). 3825 (10); Bernacci \& al. 1887 (7); Bertoni 1987 (3); Bettella 83 (3); Blanchet 2617 (10); Bocage 14 (9), 198 (9), 203 (9); 218 (9), 223 (9), 254 (9), 257 (9). 259 (9), 260 (9); Boeke 1414 (8); Boldingh 1751 (13); Boom 8005 (13); Bortoluzzi 657 (10); Brade 496 (11); Bragão 110 (10); Breedlove \& al. 23455 (16a), 23460 (13), 29686 (16a), 30388 (13); Breedlove 2039 (15), 20392 (16a), 23574 (13); Bridgewater \& al. S203 (7); Britton \& al. 5916 (13), 9916 (13), 5961 (13); Bruija 1668 (13); Brunner 1141 (7); Bufo \& al. 15 (3); Burgos 44 (13).

Cabrera \& al. 13865 (6), 21656 (6), 23435 (6); Cain 4 (13): Calderón 1888 (16a); Camp 124 (1); Campos 682 (16b?); Campos Porto 2519 (7); Carauta \& al. 3449 (4); Carauta 814 (3); Cardenas 543 (8), 5920 (8); Castellanos 24631 (3), 25198 (9); Catharin 6 (3); Cavalcanti \& al. 20.63 (7); Cavalo 808 (10), 1081 (10); Cázaro \& al. 6273 (16a); Chagas e Silva \& al. 1685 (7); Cid Ferreira \& al. 4868 (3), 9024 (3), 10234 (2); Coêlho \& al. 1713 (2), 1761 (2); Cốlho de Morães 900 (5); Conazatti 5252 (16a); Contreras 1492 (15); Coradin \& al. 560 (7); Costa \& al. 194 (11); Croat 19167 (14), 21351 (13); Cuatrecasas \& al. 30037 (13); Cuatrecasas 15255 (13), 17598 (13); Curran \& al. 987 (13).

Daly \& al. 6372 (3), 6838 (2); Damasceno \& al. 32168 (14); Damasceno Jr. 29980 (7); Davidse \& al. 11.457 (3); Díaz 395 (14); Dodson \& al. 6508 (13), 8900 (13); Dodson 6789 (12), I1322 (12); Donnell Smith (17): Duarte \& al. 1455 (9); Duarte 10451 (7); Duarte 4627 (4), 7807 (7); Ducke 35401 (14); Dunn 18741 (16b?); Duran \& al. 444 (15); Dusén 11120 (3); Dusén 4009 (3), $16679(3)$.

Edwards 688 (13); Ekman 5421 (13); Ellenberg 1382 (12), 1612 (12); Ellis \& al. 1154 (13); Emmerich 928 (3); Escobar 916 (13); Espinosa 523 (1).

Fermández Casas \& al. 4281 (6); Ferris \& al. 5172 (16a); Ferris 5535 (16a), 6087 (16a), 6260 (16a); Fevereiro 63 (9); Fiaschi \& al. 876 (11); Fiebrig 2707 (8), 6184 (3); Folli 227 (7); Fonseca \& al. 429 (9); Forzza \& al. 1365 (7); Foster \& al. 12068(14); Franca \& al. 1783(10); França (9); Franca \& al. 3630 (7); Freire \& al. 62 (3); Fries 50a (6). 1349 (14), 1924 (8); Froes 1997 (13).

Ganev 624 (10); Gaudichaud 955 (10); Gaumer 694 (15), 1921 (15); 23312 (16a), 23368 (15), 23879 (16a), 24207 (13); Gentry \& al. 8646 (3), I220I (12), 18066 (13), 21043 (14), 22688 (1), 22776 (1), 22934 (16a), 24534 (13), 29846 (13), 41357 (2), 44391 (8), 49290 (3), 57497 (2), 58360 (2); Gentry 861 (16a), 1451 (16a), 6578 (16a), 6821 (16a), 58674 (3); Giaconelli $100(6)$; Gibbs \& al. 2508 (11), 5149 (11); Giulietti \& al. 1305 (10);
Glaziou 239a (10), 2026 (11), 3769 (10), 18145a (9), 18893 (11); Goés 118 (3); Gonzales 501 (13); Groppo jr. \& al. 804 (11); Guédes 607 (9); Guillemin 743 (3), 749 (3); Gutiérrez 36 (14), 58 (2).

Harley \& al. 3444 (9); Harling 5784 (1), 6067 (1); Hartshoren \& al. 2884 (14); Hartshorne \& al. 1669 (2); Hassler $7150 d(7), 8891$ (3), 11724 (7), 12954 (7); Hatsbach 42330 (7), 46574 (7); Hatschbach \& al. 16640 (3), 52447 (7), 62447 (3); Hawkes 20 (3); Hemmendorf 102 (3); Henrickson 1600 (16a); Heringer \& al. 4760 (7), 4950 (7), 755 (5); Heringer 12150 (7); Herman 700 (13); Hernández \& al. 50 (16a); Hinton 13878 (16a); Hitchcock \& al. 7137 (16a); Hodge 543 (13); Hoehne 20218 (3); Holliday 20 (8); Hughes 1756 (15), 1806 (16b), 1814 (16b).

lltis \& al. 750 (3). 30342 (16a); Irwin \& al. 15694 (7), I795I (7); Ivanouska \& al. 2040 (3).

Jack 4782 (13); Jansen-Jacobs 2426 (13); Jørgensen 729 (7), 3933 (7); Jorgenson 1967 (6).

Kayap 1236 (14); Kellerman 4862 (16a), 5661 (15), 7976 (13); Killip \& al. 14726 (13); Kirkbride 4354 (7); Klein 5034 (3); Klug 949 (14), 4244 (14), 4304 (3); Knochbloch 7032 (16a); Koscinski 6354 (3); Krapovickas \& al. 30501 (6), 30824 (6); Krapovickas I792 (6); Krukoff 4839 (14), 5648 (13), 10067 (14); Kubitzki \& al. 9808 (7); Kuhlman 342 (7), 385 (3), 7732 (10).

Lamb 525 (13): Langlassé 739bis (16a); Lanna 629 \& Castellanos (10); Lao 18 (2), 43 (14); Laughlin 328 (16a), 2858 (13); Leoni 226 (10); Lewis \& al. 2270 (12), 3308 (1); Lindeman \& al. 553 (3); Lindman 3521 (14); Lisboa \& al. 1541 (13); Little 691 (13), 6676 (13). 6949 (13), 9761 (13), 23853 (13), 157537 (13); Little Jr. 6594 (12); Little \& al. 21063 (13); Littlejohn 9431 (13); Lundell 3569 (15), 7539 (15).

MacBride 548I (14): Macqueen \& al. 429 (16a); Magalhaes 15548 (11); Maguire \& al. 57037 (7); Mandon 825 (8); Mason \& al. 2929 (16a); Martius 3048 (14); Mathias \& al. 6051 (14); Mattos \& al. 321 (7); Mello 4302 (7); Mello \& al. 1627 (10); Mello Barretto 4011 (3); Melo 2788 (9); Mendes 264 (7); Mennewga 224 (13); Mexia 728 (16a), 1068 (13), 5354 (10); Meyer 710 (6); Miller \& al. 546 (16a); Miranda Silva \& al. 501 (7), 503 (10); Morães 1069 (3); Morong 725 (7), 1075 (6); Mosén 1123 (3), $1790(3)$.

Narvael Montes \& al. 854 (16a); Nedlson \& al. 1556 (13); Nee \& al. 26519 (8), 28815 (16a), 41688 (13), 29623 (13), 49505 (3); Nee 33868 (14). 34329 (8); Neill \& al. 6186 (2); Neill 6544 (14); Noblick 3112 (5); Núñez $\&$ al. 8262 (8), 10301 (3).

Occhioni 1918 (7), 7456 (4), 8026 (3); Oliveira 258 (9); 10182 (9).

Pabst 5606 (10), 25310 (3); Palmer 103 (13); 603 (13), 1050 (16a); Passos 34486 (3); Penland \& al. 9 (13); Pennell 3942 (13); Pennington \& al. 9250 (13), 9527 (13), 15060 (8), I7055 (14), 17121 (14); Pennington 322 (16a); Pereira \& al. 3006 (7), 3057 (7); Pereira 4491 (4), 7265 (3); Pérez Arbeláez 2472 (13); Pickel 2166 (9); Pierotti 1387 (6), 11549 (6); Pinheiro 1459 (10), 1875 (10); Pinto 75/81 (5); Pirani \& al. 2881 (10), 4276 (7), 4320 (11); Plowman \& al. 14227 (1); Poepig 32192 (2); Pott \& al. 834 (7), 2799 (7); Pott 2132 (14), 5502 (14); Prance \& al. 26169 (14), 59311 (14); Prance 26254 (7); 
Pringle 4733 (16a), 8212 (16a), 8212 (16a), 9685 (16a); Proctor \& al. 21973 (13); Proctor 29999 (13), 32859 (13); Purpus 4009 (16a), 8770 (16a).

Queiroz \& al. 963 (10), 2160 (3), 2189 (5), 3994 (7). 4564 (7), $6121(7), 6246(7)$.

Reitz \& al. 12164 (3); Reitz 3695 (3); Revilla 36 (14); Reznicek \& al. 807 (16b?); Rizzini \& al. 32 (7). 1120 (11); Robinson 163 (16a), 219 (13); Rodríguez \& al. 6365 (13); Rodríguez 523 (3), 729 (3); Romero Castañeda 9830 (13); Rose 1705 (16a), 2494 (16a). 3096 (16a), 11158 (16a), 12372 (13); Rose \& al. 3400 (13), 4071 (13), 4337 (16a), 4670 (16b), 4742 (16a), 4812 (16a), 6564 (16b), 7539 (16a), 11407 (16b), 13629 (16a), 14541 (16a), $20296(10)$; Rozza 263 (3); Ruiz 1182 (14); Rusby 6612 (3).

Salazar 854 (16a); Salgado 138 (9); Salinas \& al. F3582 (16b), F3749 (16a); Salviani \& al. 2251 (7), 2256 (7), 2259 (7), 2264 (7); Sandeman 4843 (6); Santos 87 (7), 147 (3), 1579 (5), 2283 (5); Sawada 6 (2); Schatz \& al. 724 (14), 873 (14); Schinini \& al. 16563 (6), 16751 (3); Schinini 14730 (3); Schipp 1235 (13); Schunke 3238 (14), 5326 (2), 5922 (2), 8402 (14); Schwarz 4107 (3); SEF 10027 (14); Semir \& al. 30456 (3); Semir 10929 (11), 304600 (3), 33615 (7); Silva \& al. 274 (9); Smith \& al. 11811 (3), 3639 (16b); Smith 1567 (16a), 1887 (13); Solheim \& al. 1185 (16a); Solomon 7604 (3); Soukup 513 (8); Souza 244 (4); Sousa Souza 27 (5); Spegazzini 33933 (6); Speltman \& al. 1899 (13); Spruce 3928 (1); Steyermark 61707 (13), 61774 (13), 86943 (13); Stork 4011 (13); Stranghetti 303 (7); Stuckert 19971 (6); Stuts 1602 (3); Sucre 7578 (10).

Taylor 134 (13); Tellez \& al. 3545 (15); Timaná \& al. 3027 (14); Tomasetto 157 \& al. (7); Tomasetto 287 (7); Ton 3754 (13); Trinta \& al. 1917 (5); Trinta 549 \& al. (4). Ugent 5106 (8): Ule 9597 (2).

Valverde 326 (12); Van Royen 1050 (13); Vargas 7195 (8); Vasquez \& al. 3027 (14), 8613 (14); Vasquez 12 (3); Velasquez 21248 (7); Ventura 3493 (16a); Venturi 149c (6), 3235 (6), 6045 (6); Vieira \& al. 554 (4).

Walker 258 (13); Wall \& al. 162 (6); Walther \& al. 41.12 (7); Weberbauer 5874 (8), 6195 (1), 6349 (1); Wehling 122244 (8); West 8358 (6); Wiggins \& al. 449 (16a); Wiggins 7341 (16a); Wood 8007(8); Woolston 691 (7); Woytkowski 6403 (14), 6817 (1); Wurdack \& al. 39437 (13).

Zanoni \& al. 10817 (13); Zanoni \& al. 29306 (13); Zardini \& al. 10874 (3); Zardini 4633 (7), 11323 (3).

\section{INDEX TO SCIENTIFIC NAMES}

(Accepted names are in roman type; the main entry for each is in boldface. Synonyms are in italics)

Bombax L.

axillare Moç. \& Sessé, 291

cumanense Kunth, 285

erianthos Cav., 281

mompoxense Kunth. 285

pentandrum L., 285

ventricosum Arrud., 273
Ceiba Mill.

acuminata (S. Watson) Rose, 292

aesculifolia (Kunth) Britten \& Baker f., 291 subsp. aesculifolia, 292

subsp. parvifolia (Rose) Gibbs \& Semir, 295

anfractuosa M. Gómez, 285

boliviana Britten \& Baker f., 278

burchelli K. Schum., 288

chodatii (Hassl.) Ravenna, 274

crispiflora (Kunth) Ravenna, 273

erianthos (Cav.) K. Schum., 281

fiebrigii Hochr., 275

glaziovii (Kuntze) K. Schum., 280

grandiflora Rose, 292

incana (Robyns) Ravenna, 274

insignis (Kunth) Gibbs \& Semir, 267

jaibana Ravenna, 275

jasminodora (A. St. Hil.) K. Schum., 282

lupuna Gibbs \& Semir, 270

mandoni Britten \& Baker f., 278

pallida Rose, 292

parvifolia Rose. 295

pentandra (L.) Gaertn., 285

pubiflora (A. St. Hil.) K. Schum., 275

samauma (Mart.) K. Schum., 288

schottii Britten \& Baker f., 290

sipolisii K. Schum. \& Schwacke, 282

soluta (Donn. Sm.) Ravenna. 295

speciosa (A. St. Hil.) Ravenna, 271

tomentosa (B.L. Rob.) Britten \& Baker f., 292

trischistandra (A. Gray) Bakh., 284

tunariense Kuntze, 278

ventricosa (Nees \& Mart.) Ravenna, 273

Chorisia Kunth

chodatii Hassl., 274

crispiflora Kunth, 278

grandiflora Rusby, 278

incana Robyns, 274

insignis Kunth, 267

integrifolia Ulbr., 268

pubiflora (A. St. Hil.) G. Dawson, 275

soluta Donn. Sm.. 295

speciosa A. St. Hil., 291

ventricosa Nees \& Mart., 273

Eriodendron DC.

acuminatum S. Watson, 292

aesculifolium (Kunth) DC., 291

grandiflorum (Rose) Conz., 292

jasminodorum A. St. Hil., 282

leiantherum DC., 281

pubiflorum A. St. Hil., 275

samauma Mart., 288

tomentosum B.L. Rob., 292

trischistandrum A. Gray, 284

Xylon Kuntze

erianthos (Cav.) Kuntze, 281

glaziovii Kuntze, 280

tunariensis Kuntze, 278
Editado por Carlos Aedo Aceptado para publicación: 28-V-2003 